IZA DP No. 8200

Private Notes on Gary Becker

James J. Heckman

May 2014 


\title{
Private Notes on Gary Becker
}

\author{
James J. Heckman \\ University of Chicago \\ and IZA
}

\section{Discussion Paper No. 8200 \\ May 2014}

\author{
IZA \\ P.O. Box 7240 \\ 53072 Bonn \\ Germany \\ Phone: +49-228-3894-0 \\ Fax: +49-228-3894-180 \\ E-mail: iza@iza.org
}

\begin{abstract}
Any opinions expressed here are those of the author(s) and not those of IZA. Research published in this series may include views on policy, but the institute itself takes no institutional policy positions. The IZA research network is committed to the IZA Guiding Principles of Research Integrity.

The Institute for the Study of Labor (IZA) in Bonn is a local and virtual international research center and a place of communication between science, politics and business. IZA is an independent nonprofit organization supported by Deutsche Post Foundation. The center is associated with the University of Bonn and offers a stimulating research environment through its international network, workshops and conferences, data service, project support, research visits and doctoral program. IZA engages in (i) original and internationally competitive research in all fields of labor economics, (ii) development of policy concepts, and (iii) dissemination of research results and concepts to the interested public.
\end{abstract}

IZA Discussion Papers often represent preliminary work and are circulated to encourage discussion. Citation of such a paper should account for its provisional character. A revised version may be available directly from the author. 
IZA Discussion Paper No. 8200

May 2014

\section{ABSTRACT}

\section{Private Notes on Gary Becker ${ }^{*}$}

This paper celebrates the life and contributions of Gary Becker (1930-2014).

JEL Classification: B31, J24

Keywords: human capital, human behavior, lifetime contributions, tribute

Corresponding author:

James J. Heckman

Department of Economics

University of Chicago

1126 East 59th Street

Chicago, Illinois 60637

USA

E-mail: jjh@uchicago.edu

* Presented at the Milton Friedman Institute during a Conference in Honor of Gary Becker, February 11, 2011.

Editor's note: We are pleased to publish this paper in the IZA series as a tribute to Gary Becker, who was one of the most influential labor economists of our time and a strong supporter of IZA. 


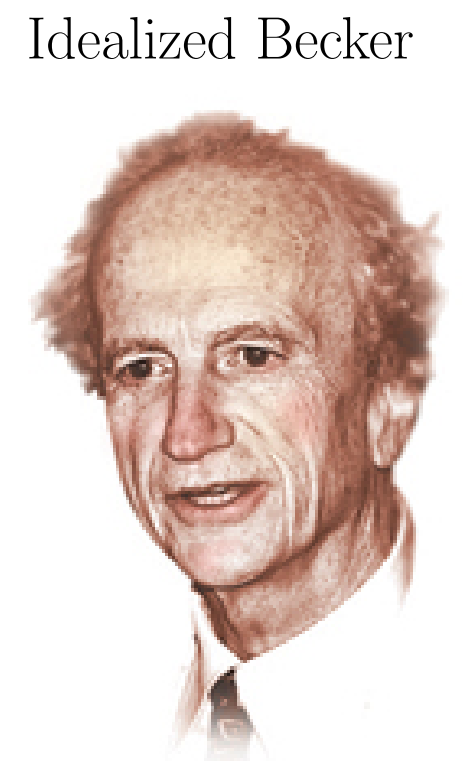

I have been asked to talk about Gary Becker this evening. This is a daunting task in light of the volumes of essays written about the man and his work, some of them by distinguished guests in this room.

Moreover, it is made all the more difficult by the remarks made by Milton Friedman some 10 years ago when he spoke about Gary Becker at a faculty-wide award ceremony that recognized Gary as an outstanding contributor to intellectual life of the university over the long haul — the Phoenix Award. 
Friedman said, unequivocally,

"Gary Becker is the Greatest Social Scientist Who Has Lived and Worked in the Last Half Century."

That pretty much says it all, and I agree with this statement.

So what can I add to this and all of the other praise heaped upon Gary Becker over the years? Since his work is so well known and so much discussed, it seems difficult to contribute much to what people know about it, and that may well prove to be true.

But as a member of the crowd in many past celebrations, I have not always agreed with the statements made about Gary or the description of his work, and this is my chance to cast Gary Becker in a somewhat different light than many have done in earlier talks.

I noted few attempts to tie together the continuities in his life and work, something I will attempt to do this evening. I also want to cast him correctly as an empirical economic scientist, who has created important bodies of economic theory and has launched and guided a massive body of empirical research in economics.

At my own peril, I will revise previous descriptions and show how 
his life is the manifestation of unique personality and intellectual traits that have persisted over his adult life.

I do so ignoring the warnings of George Stigler, who, when reviewing a history of economic thought by Lionel Robbins, wrote in response to his own question,

"What relevance have the details of a man's personal life to the nature of his scientific work?"

the remark:

"I am tempted to answer: biography distorts rather than illuminates the understanding of scientific work." -Stigler (1970)

I will not get into too many personal details, except where they are relevant or interesting. He has an interesting personal life, is a power hitter, a man of much personal and intellectual strength. Unknown to most of you, he has a secret life as a body builder and champion athlete — but I will not dwell much on that aspect tonight.

His sister Natalie tells me that Gary was very athletically inclined and pursued a lot of sports - handball and stickball. 

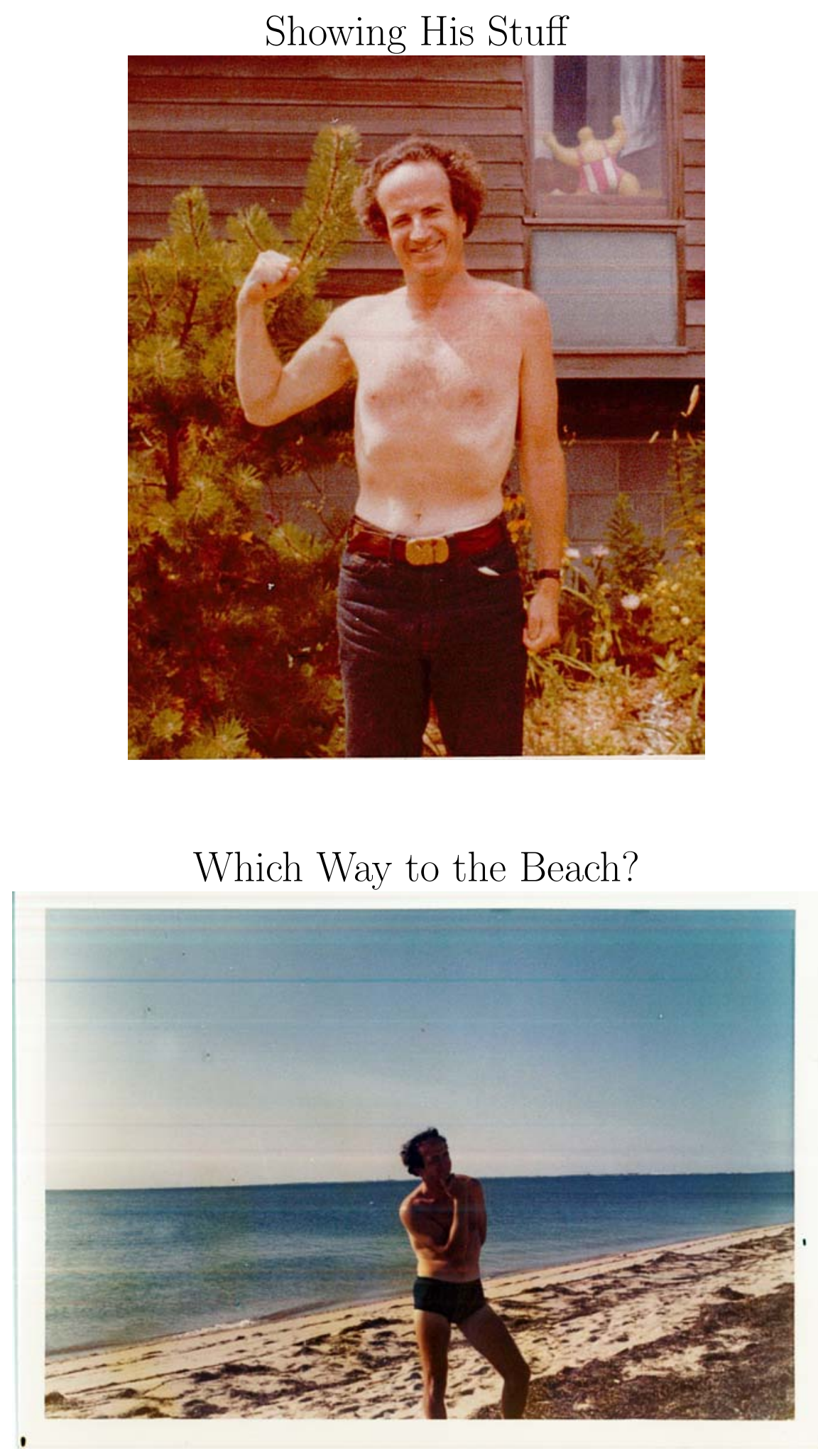
So how can I describe him? Attracted by the physical similarity between Becker and Isaac Newton, I was tempted to develop an entire speech around that theme.

\section{Gary Becker-Our Isaac Newton}

1. Show photos of Becker and portraits of Newton.

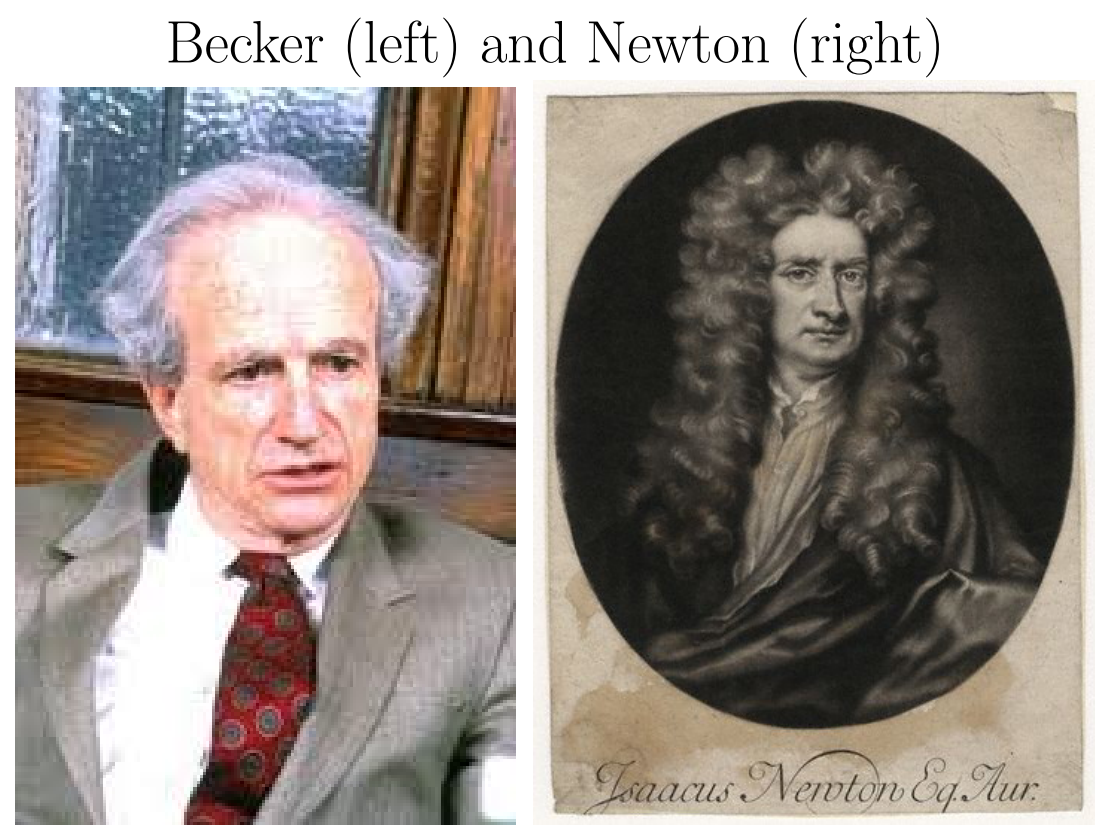

There is an obvious physical similarity, and they have other traits in common.

1. Enormous contributions of each - wide ranging across a variety of topics within their fields. Arguably, the full contributions of 
each man are still not yet widely understood - each did and has done more than is commonly thought.

Newton: optics, planetary motions, tides, calculus, gravity.

Becker: unveiling the mysteries of the labor market (turnover, wages, migration, schooling ability) and other features like the deferred compensation, crime, addiction, fertility, preferences, and the economics of the family.

2. Both were focused people - kept problem in head (perseverant; focused). Keynes, in describing Isaac Newton, wrote that:

"I believe that the clue to his [Newton's] mind is to be found in his unusual powers of continuous concentrated introspection. A case can be made out, as it also can with Descartes, for regarding him as an accomplished experimentalist. Nothing can be more charming than the tales of his mechanical contrivances when he was a boy. There are his telescopes and his optical experiments. These were essential accomplishments, part of his unequalled all-round technique, but 
not, I am sure, his peculiar gift, especially amongst

his contemporaries.

His peculiar gift was the power of holding continuously in his mind a purely mental problem until he had seen straight through it. I fancy his pre-eminence is due to his muscles of intuition being the strongest and most enduring with which a man has ever been gifted. Anyone who has ever attempted pure scientific or philosophical thought knows how one can hold a problem momentarily in one's mind and apply all one's powers of concentration to piercing through it, and how it will dissolve and escape and you find that what you are surveying is a blank. I believe that Newton could hold a problem in his mind for hours and days and weeks until it surrendered to him its secret. Then being a supreme mathematical technician he could dress it up, how you will, for purposes of expo- 
sition, but it was his intuition which was preeminently extraordinary - 'so happy in his conjectures,' said de Morgan, 'as to seem to know more than he could possibly have any means of proving.' The proofs for what they are worth, were, as I have said, dressed up afterwardsthey were not the instrument of discovery.

There is the story of how he informed Halley of one of his most fundamental discoveries of planetary motion. 'Yes,' replied Halley, 'but how do you know that? Have you proved it?' Newton was taken aback-'Why, I've known it for years,' he replied. 'If you'll give me a few days, I'll certainly find you a proof of it' - as in due course he did. ...

His experiments were always, I suspect, a means, not of discovery, but always of verifying what he knew already." -Keynes (1963, pp. 312-313) 
3. Both laid the foundations for a variety of fields that grew up in their wake. The life work of many eminent scholars sitting in this room is based on amplifying, and often substantially extending one or two of Gary Becker's many creative ideas. Saying that takes nothing from anyone here for indeed the room is distinguished. Rather it gives a good gauge of the magnitude of his contributions.

4. But the analogy with Newton does not carry through, and I will not pursue it. While Becker and Newton both have powerful intuitions, in the end, the two are different and the comparison breaks down.

5. Newton engaged in mysticism. His papers show that he viewed his work in science as his attempt to understand the mysteries of the Divine. Can Gary Becker be accurately described in this way? Where the "market" or the "power of optimization" replaces God? Tempting, but in the end not a very good analogy. 
6. Before continuing, I should probably tell you my qualifications for undertaking this task. I never took a formal class with him, nor did he supervise my thesis, but his work and ideas have been a constant presence in my approach to economics (as it has for many of you) since my graduate student days when I first encountered his work and ideas.

\section{James Heckman as an Observer, Colleague, and Friend of Gary Becker-How I Came to Know Him?}

1. As a grad student at Princeton in the 1960s, some of the teachers and senior students spoke of the interesting work by Becker. Some had been Becker's teachers and had known him as a student. By the time I entered the profession, Gary Becker, not yet 40, had already made definitive contributions to the following areas of knowledge:

(a) Racial discrimination

(b) Human capital and the study of schooling, wage dynamics, and worker-firm relationships 
(c) Time allocation and nonmarket household production

(d) Fertility (babies as durable goods)

(e) Theory of irrational behavior (how many prediction of demand theory were consequences of the budget constraint not preferences)

2. If Becker had stopped working at this point before he was 40 and cashed out or gone into a mode of politics, popularization, or cuteness, he would have had a more distinguished career than most economists, including most of the very distinguished economists sitting in this room.

3. Like many of you, I devoured his work and the related work on human capital by his colleague and friend Jacob Mincer.

4. It was, for me, an antidote to a lot of formal and sometimes sterile economics.

5. At one stage in my graduate career, I was interested in Development economics. Took classes and worked with Arthur Lewis, who shared a Nobel Prize with Ted Schultz in 1979. 
6. Personal story about the focus of the younger economists at Princeton at the time on Development as an integer programming problem. If we knew the dual prices, we knew the optimum allocations. My reaction-so what? Where did the dual prices come from?

7. Becker and Mincer were creating a powerful body of empirically motivated work that, to my view and to that of many in this room, made his quarter of economics into a science; theory matched with data.

8. Contemporary commentary not always favorable on the work in the 1960s - but always quite favorable on the person: his intelligence and creativity. He was just viewed as an eccentric. A very bright guy wasting his time on oddball topics.

9. An intuitive economist swimming against the high and rising tide of formalism in economics. 


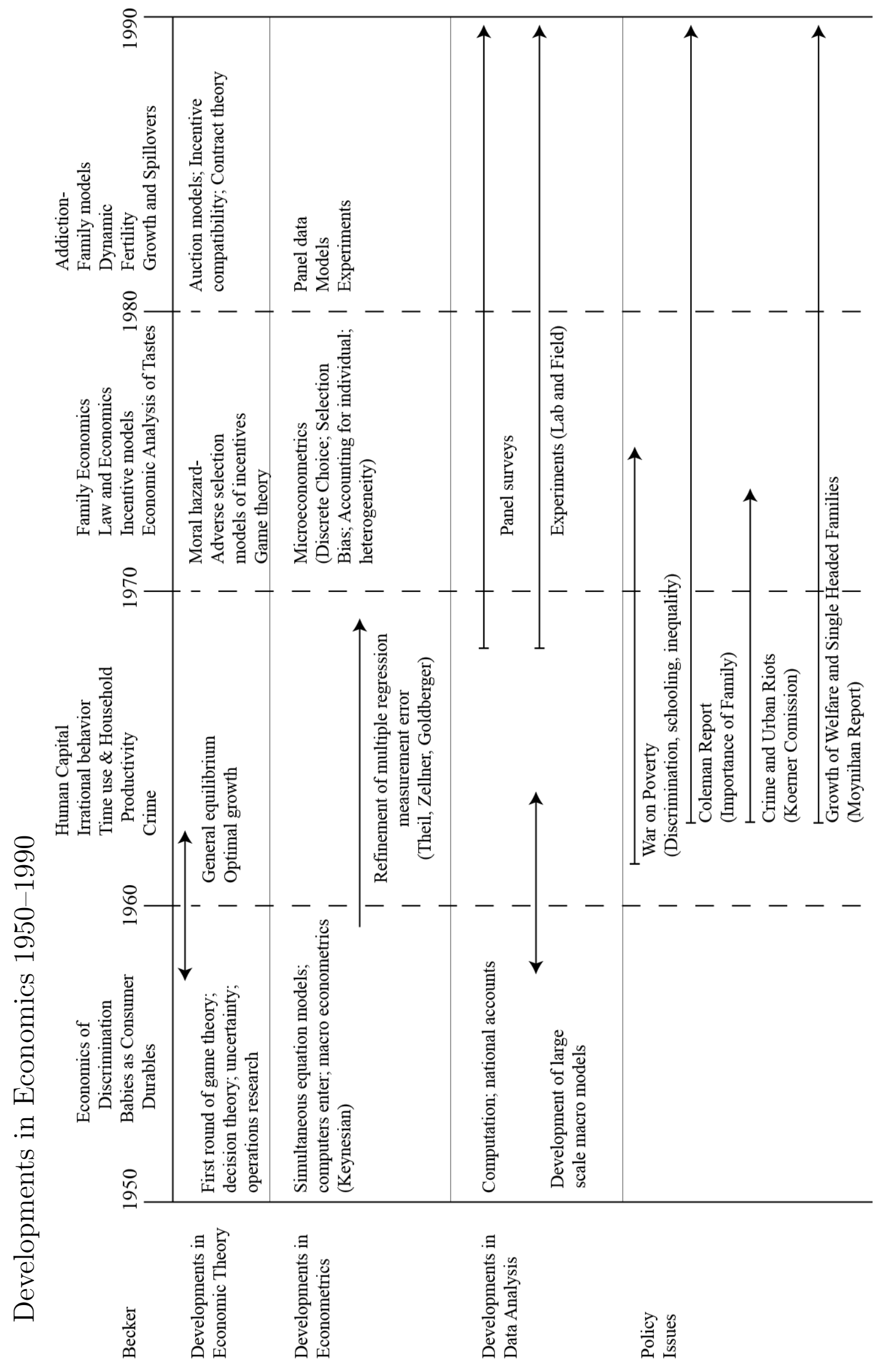


One of my first systematic readings of a Becker paper was his analysis on Fertility 1960.

Course on demography and economic development.

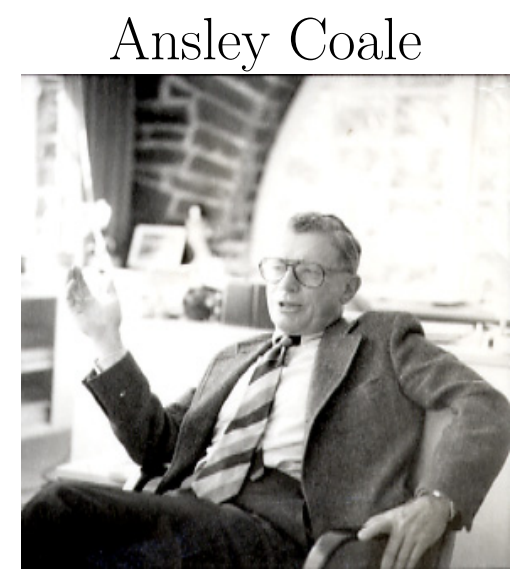

4. Harvard Professor James Duesenberry commented on Becker's early paper on Fertility at an NBER conference in the late 50s. This conference and the commentary are frequently mentioned by Friedman, Stigler, and Becker and others. The urban legend has it that he was violently attacked by many participants at that conference and his discussant, James Duesenberry. This may well be true. But reading the written record of the conference suggests that Duesenberry had some useful, if imprecisely formulated, objections. 


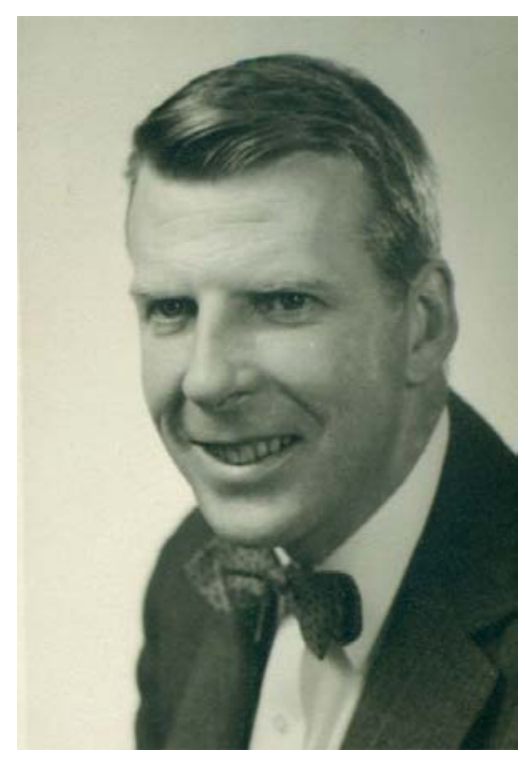

"For many years economists have taken variations in rates of population growth, and in family size, as data which help to explain various economic phenomena but which cannot themselves be explained in terms of economic theory. Becker has done us a real service in bringing economic analysis to bear on the problem once more. He has not only worked out the implications of traditional economic theory for demographic theory but has also gone some distance in testing those implications against the empirical data."

"Becker argues that those couples with sufficient contra- 
ceptive knowledge to control births have to decide how many children to have. For most people, children produce certain satisfactions and have a net cost. In those circumstances we expect (with some qualifications) that the number of children per family will rise with income just as we expect the number of cars or chairs or cubic feet of housing space per family to rise with income. But just as in those cases we expect the quality of cars or chairs or houses to rise with income as well as the number, we also expect the quality of children to rise with income as well as the number. That is, we expect the children of the rich to be better housed, fed, and educated than those of the poor."

"After reviewing the implications of economic theory, Becker then faces the fact that for many years the raw data on differential fertility have shown a fairly strong negative relationship between variations in income and variations in numbers of children per family. Moreover, until recently the average number of children per completed family has been de- 
clining although average family income has been rising secularly."

"Becker maintains that the negative correlation between income and family size is due to the negative association between income and knowledge of contraceptive methods. I think that most of us would agree that differential knowledge does explain a large part of the apparent negative relation between income and family size."

"... I must say that the evidence he cites did not strike me as exactly overwhelming."

"...there are, I think, some reasons for thinking that Becker's theoretical case may not be so open and shut as appears. Those reasons have to do with the nature of the 'cost' of children and with the limitations on the possibility of substitution between quantity and quality of children."

"Becker has taken the occasion to correct the simpleminded who fail to distinguish between the cost of children of given quality and expenditure per child..." 
"Questions of semantics aside, there is an important substantive difference between Becker's approach and that taken by economists whose approach is, if he will excuse the expression, more sociological."

"I used to tell my students that the difference between economics and sociology is very simple. Economics is all about how people make choices. Sociology is all about why they don't have any choices to make."

"...I submit that a sociologist would take the view that given the educational level, occupation, region, and a few other factors, most couples would consider that they have a very narrow range of choice. To take only one example, I suggest that there is no one in the room, not even Becker, who considers himself free to choose either two children who go to university or four children who stop their 
education after high school. It may be said that that still leaves lots of room for variation, but I think it can be said that no one in this room considers seriously having, say, four children who attend third-rate colleges at low cost per head or three who attend better ones."

"Effective freedom of choice between quantity and quality of children is also limited by more mundane and mechanical considerations. The principle of substitution which is at the basis of Becker's argument suggests that if the parents have low quality children, as he puts it, they can spend more of their income on something else. Quality of children means, in Becker's terminology, nothing more than expenditure per child (with a given price schedule). But in many respects the standard of living of the children is mechanically linked to that of the parents. Is it possible to have crowded housing conditions for the children and uncrowded conditions for the parents? As the 
father of four I am in a position to answer with an unqualified negative. Children may eat a different menu from their parents, but if so, it is because they like peanutbutter sandwiches. I could go on but I am sure it's unnecessary. A final point in this connection is the non-cash cost of improving quality in children. Becker has used the term quality as though it were just another expression for expenditure at constant prices... But even if one had nothing else to do, the marginal disutility of Cub Scout and PTA meetings rises rapidly. These noncash costs must certainly be of some importance in determining family size."

"...He is correct, of course, but the investment of time in children is not a matter of individual choice any more than the investment of money. The time which parents spend on children is largely determined by social conventions. Those conventions differ among social 
classes. Since social class is often associated with income, the non-cash costs I have mentioned will influence the apparent relation between income and family size in many crosssections."

"Social class in turn will be associated with income but not in a unique way. In some societies it may turn out that the "cost" of children rises faster than income, in others more slowly."

The written commentary by Duesenberry was not as wild or off the wall as it may sound.

Over his lifetime, Becker rephrased and sharpened these questions. This process led him to a version of the modern theory of fertility.

I will return to this point at several times throughout the lecture. 
5. My first academic job out of grad school: Columbia - went there hoping to work with Gary Becker; as of March 1970 when I had to decide where to go, he was going back to Columbia, but he changed his mind! He left me high and dry. But with Jacob Mincer and a flock of his first rate, highly motivated, and intellectually engaged students. So even though I did not then work with him directly, I saw his legacy and the devotion of his scholars and students first hand.

(a) First personal interaction with him came in Jacob Mincer's kitchen, Fall 1970; we argued over a model of theory of marriage that I had written that featured the wife as a domestic servant. Talked me out of it.

(b) Came to Columbia and NBER often enough - could interact first-hand; he gave many workshops.

(c) Served on student thesis committees at Columbia (inherited his load) —wonderful learning experience (with his students and with him when he came to their defenses). 
(d) Students and faculty in awe of him. He was a presence I learned about through his reflection on the lives of those around him!. People like Kelvin Lancaster and Bill Vickrey sad he had left.

(e) Cargo cults and story of the reserved chair at the Labor Workshop and a sense of deep respect.

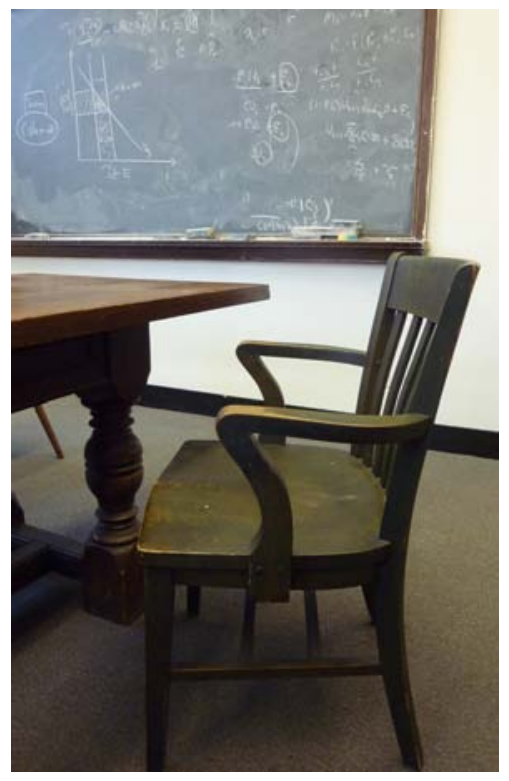

6. He invited me to come to Chicago and I got an offer (along with J. Mincer). He initiated me into the world of Chicago with Friedman, Stigler, and a whole range of creative people and interesting ideas. Came to know him as a colleague. 
7. Have been a first-hand observer since 1973 with a few breaks over the years.

8. Have attended many events in his honor, especially since the Nobel Prize, awarded more than 18 years ago. 


\section{Traits About Gary Becker That Strike Anyone Who Interacts With Him: A Psychological Analysis}

Violating Stigler's Maxim, let me venture a psychological characterization of Gary Becker's traits. I do so with some trepidation since his sister, Natalie, a psychoanalyst, sitting in this room is better suited to the task.

As some of you know, in my recent work I have been researching the importance, stability and origins of personality traits and cognition. I view this as building a foundation for understanding the origins of inequality and for a more nuanced understanding of what human capital is and how it is created.

Interesting to make a case study of him 
The first thing that strikes you about him is his Intelligence and Creativity.

1. Highly intelligent. Quick to get to the key point of any argument.

2. Very creative. Able to shed new light on almost any question.

3. Highly knowledgeable - interested in a variety of real-world issues and theoretical models with a deep grasp of both theoretical and empirical content. 


\section{Intelligence and Its Facets}

Math Reasoning

Quantitative Reasoning

Math Problems

\section{$\mathrm{Gc}$}

(Crystallized Intelligence)

Verbal Comprehension

Lexical Knowledge

Reading Comprehension

Reading Speed

"Cloze"

Spelling

Phonetic Coding

Grammatical Sensitivity

Foreign Language

Communication

Listening

Oral Production

Oral Style

Writing

\section{Visual Perception}

Visualization

Spatial Relations

Closure Speed

Closure Flexibility

Serial Perceptual Integration

(Fluid Intelligence)

Sequential Reasoning

Inductive Reasoning

Quantitative Reasoning

Spatial Scanning

Imagery

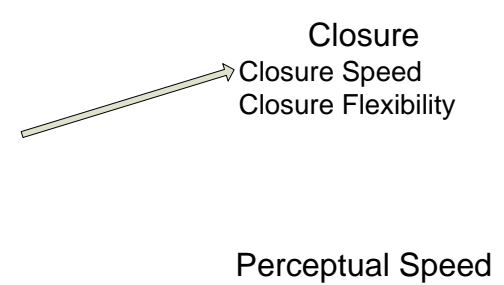

Number Computation

RT and other Elementary Cognitive Tasks

Stroop

Clerical Speed

Digit/Symbol

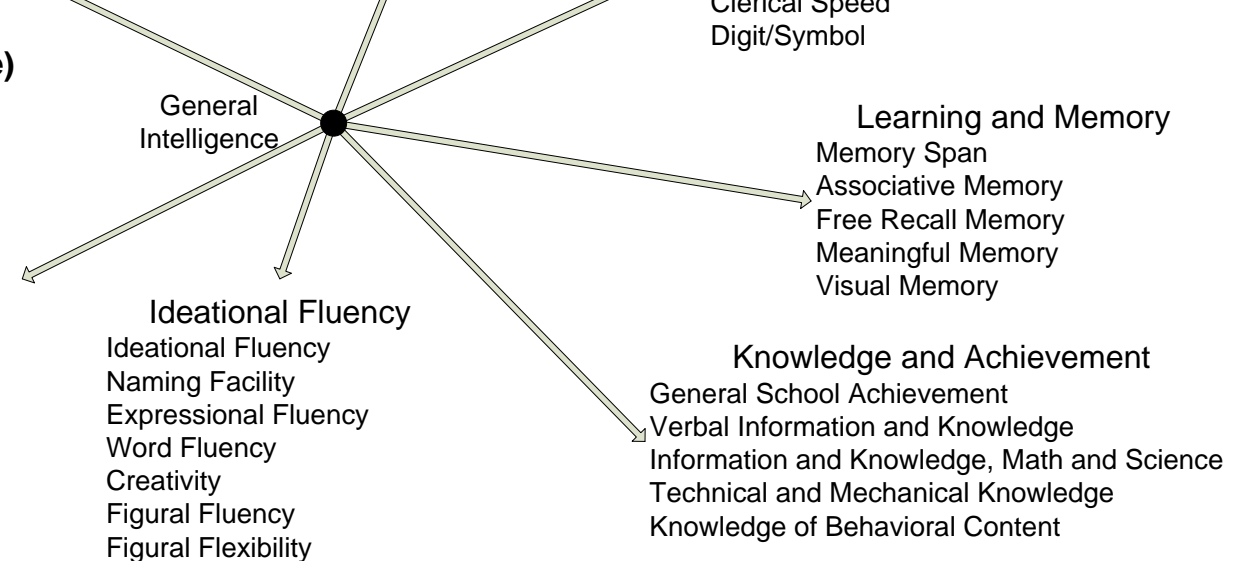




\section{Personality Traits}

1. Focused - like Newton - works on problems until he finishes them and keeps them in mind.

2. Polite and courteous; respectful of all - even the most ignorant as long as they are respectful. High on agreeableness and courtesy.

3. An anomaly at Chicago; especially in the 1970s when blunt talk and often withering sarcasm was the rule (e.g., Milton Friedman and George Stigler). 


\section{The Big Five Personality Domains and Their Facets}

\begin{tabular}{|c|c|c|c|}
\hline $\begin{array}{c}\text { Big Five Personality } \\
\text { Factor }\end{array}$ & $\begin{array}{c}\text { American Psychology } \\
\text { Association Dictionary } \\
\text { description }\end{array}$ & $\begin{array}{l}\text { Facets (and correlated } \\
\text { trait adjective) }\end{array}$ & Related Traits \\
\hline Conscientiousness & $\begin{array}{l}\text { "the tendency to be } \\
\text { organized, responsible, } \\
\text { and hardworking" }\end{array}$ & $\begin{array}{l}\text { Competence (efficient) } \\
\text { Order (organized) } \\
\text { Dutifulness (not careless) } \\
\text { Achievement striving } \\
\text { (ambitious) } \\
\text { Self-discipline (not lazy) } \\
\text { Deliberation (not } \\
\text { impulsive) }\end{array}$ & $\begin{array}{l}\text { Grit } \\
\text { Perseverance } \\
\text { Delay of gratification } \\
\text { Impulse control } \\
\text { Achievement striving } \\
\text { Ambition } \\
\text { Work ethic }\end{array}$ \\
\hline $\begin{array}{l}\text { Openness to } \\
\text { Experience }\end{array}$ & $\begin{array}{l}\text { "the tendency to be open } \\
\text { to new aesthetic, } \\
\text { cultural, or intellectual } \\
\text { experiences" }\end{array}$ & $\begin{array}{l}\text { Fantasy (imaginative) } \\
\text { Aesthetic (artistic) } \\
\text { Feelings (excitable) } \\
\text { Actions (wide interests) } \\
\text { Ideas (curious) } \\
\text { Values (unconventional) }\end{array}$ & - \\
\hline Extraversion & $\begin{array}{l}\text { "an orientation of one's } \\
\text { interests and energies } \\
\text { toward the outer world } \\
\text { of people and things } \\
\text { rather than the inner } \\
\text { world of subjective } \\
\text { experience; } \\
\text { characterized by } \\
\text { positive affect and } \\
\text { sociability" }\end{array}$ & $\begin{array}{l}\text { Warmth (friendly) } \\
\text { Gregariousness } \\
\text { (sociable) } \\
\text { Assertiveness (self- } \\
\text { confident) } \\
\text { Activity (energetic) } \\
\text { Excitement seeking } \\
\text { (adventurous) } \\
\text { Positive emotions } \\
\text { (enthusiastic) }\end{array}$ & - \\
\hline Agreeableness & $\begin{array}{l}\text { "the tendency to act in a } \\
\text { cooperative, unselfish } \\
\text { manner" }\end{array}$ & $\begin{array}{l}\text { Trust (forgiving) } \\
\text { Straight-forwardness (not } \\
\text { demanding) } \\
\text { Altruism (warm) } \\
\text { Compliance (not } \\
\text { stubborn) } \\
\text { Modesty (not show-off) } \\
\text { Tender-mindedness } \\
\text { (sympathetic) }\end{array}$ & $\begin{array}{l}\text { Empathy } \\
\text { Perspective taking } \\
\text { Cooperation } \\
\text { Competitiveness }\end{array}$ \\
\hline $\begin{array}{l}\text { Neuroticism/ } \\
\text { Emotional Stability }\end{array}$ & $\begin{array}{l}\text { Emotional stability is } \\
\text { "predictability and } \\
\text { consistency in emotional } \\
\text { reactions, with absence } \\
\text { of rapid mood changes." } \\
\text { Neuroticism is "a } \\
\text { chronic level of } \\
\text { emotional instability and } \\
\text { proneness to } \\
\text { psychological distress." }\end{array}$ & $\begin{array}{l}\text { Anxiety (worrying) } \\
\text { Hostility (irritable) } \\
\text { Depression (not } \\
\text { contented) } \\
\text { Self-consciousness (shy) } \\
\text { Impulsiveness (moody) } \\
\text { Vulnerability to stress } \\
\text { (not self-confident) }\end{array}$ & $\begin{array}{l}\text { Internal vs. External } \\
\text { Locus of control } \\
\text { Core self-evaluation } \\
\text { Self-esteem } \\
\text { Self-efficacy } \\
\text { Optimism } \\
\text { Axis I } \\
\text { psychopathologies } \\
\text { (mental disorders) } \\
\text { including depression } \\
\text { and anxiety disorders }\end{array}$ \\
\hline
\end{tabular}


Becker is high on all the positive traits. Gets to the point but is polite. He suffers fools but not gladly. Not overly extraverted, but that is not predictive of many positive outcomes. Blunt but much less so than the rule of Chicago in the 1970s that I came to know. 


\section{An Intellectual Biography: The Role of Brilliance, Persistence, and Creativity}

1. Becker's basic life data are well known, but facts about early family life not so well known, and I can contribute little to our understanding of it. Parents and environment (New Deal Democrats, but from all accounts he was not very political)

2. Born in Pottsville, PA, December 2, 1930 (coal mining town). Grew up in Brooklyn - graduated from James Madison High School about six years later than his lifelong antagonist Robert Solow. Early years and early influences not so well documented, so much as I would like to tell you about them, I simply do not know enough. 
His sister Natalie writes about his family influence, "[W]e all were supposed to study hard, to focus, to plan ahead, to think independently, to not follow the crowd, to use your brains as they would say. Gary was intense about the Giants, about ping pong, stickball, handball, math problems, about strength, competition, ringolevio, not about religion, politics, art, poetry." -Natalie Becker (2011) 


\section{Becker as a Child (The Smaller Boy)}
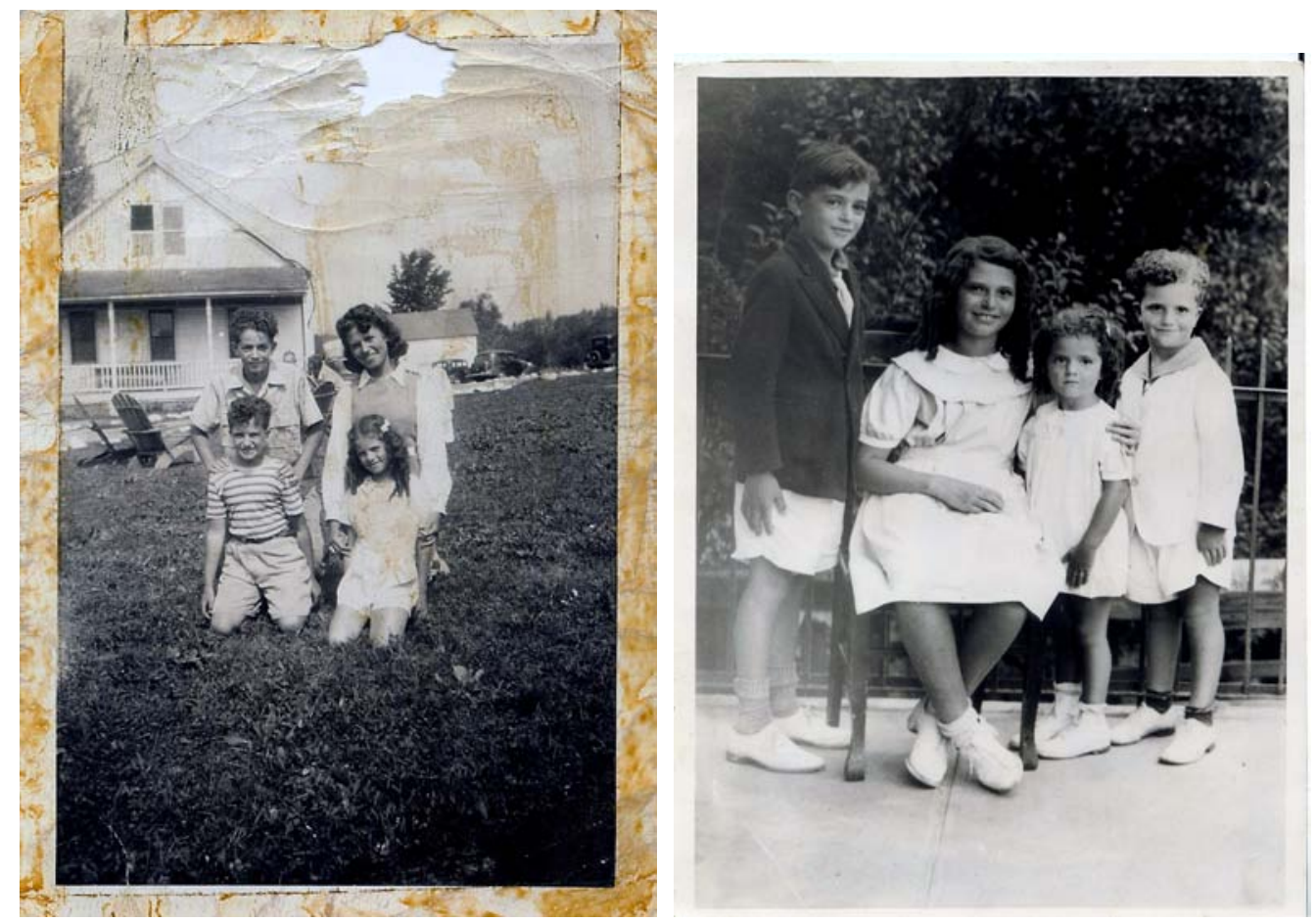

3. As a Giants fan in Brooklyn, he was already running against the tide! He and his brother argued passionately over solutions to math problems. Gary also writes about his interest in social problems. 
James Madison High School

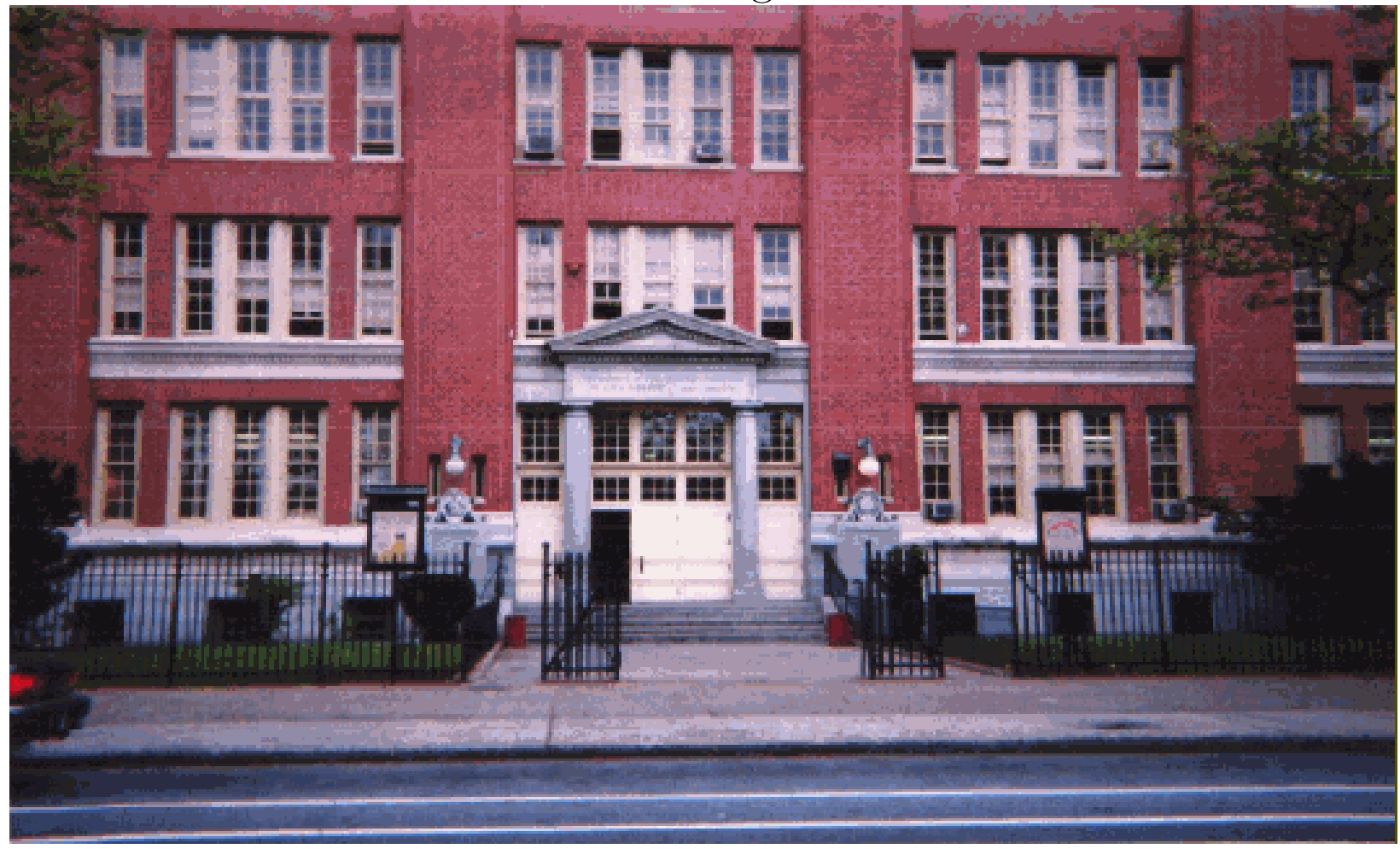

Lifetime Antagonist and Fellow Madison Alum, Robert Solow

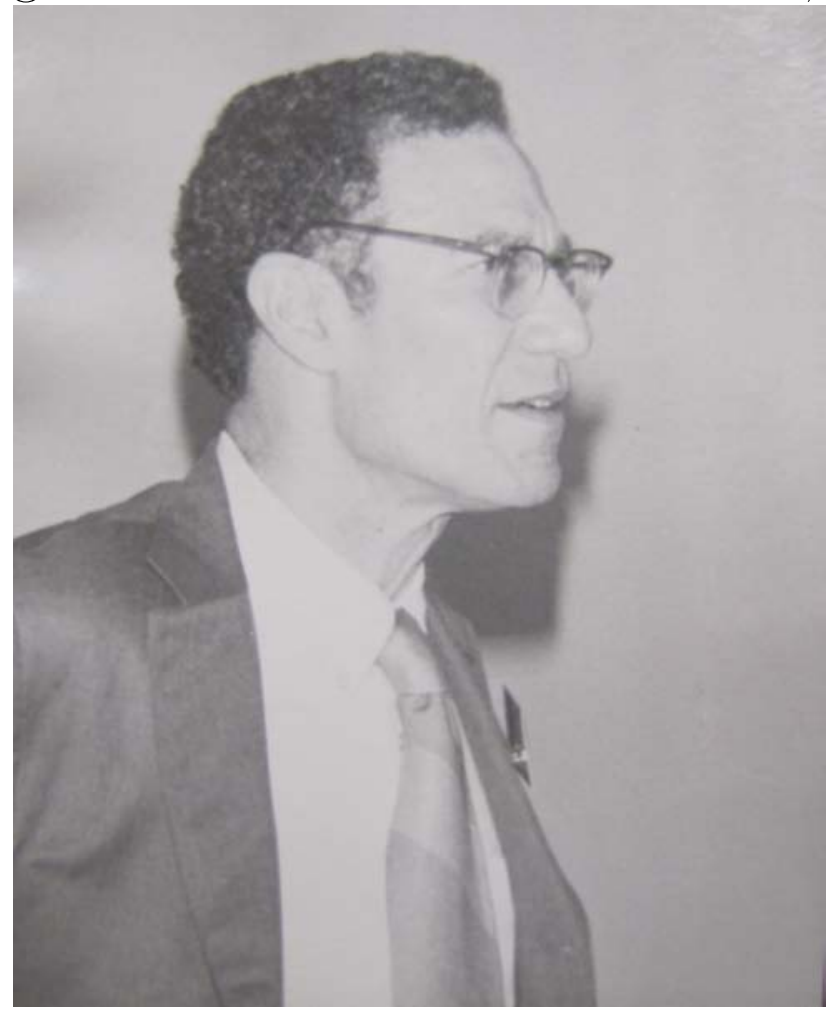


4. His intelligence was quickly manifest: He emerged as an outstanding person early, was highly regarded early and did everything very well and very quickly. In his biography, he claims to be an indifferent student but records show otherwise. Admitted to Princeton at age 17.

(a) In his biography, he notes that he chose math club over handball club in high school.

(b) Competed successfully against Stuyvesant and Bronx School of Science in math competitions.

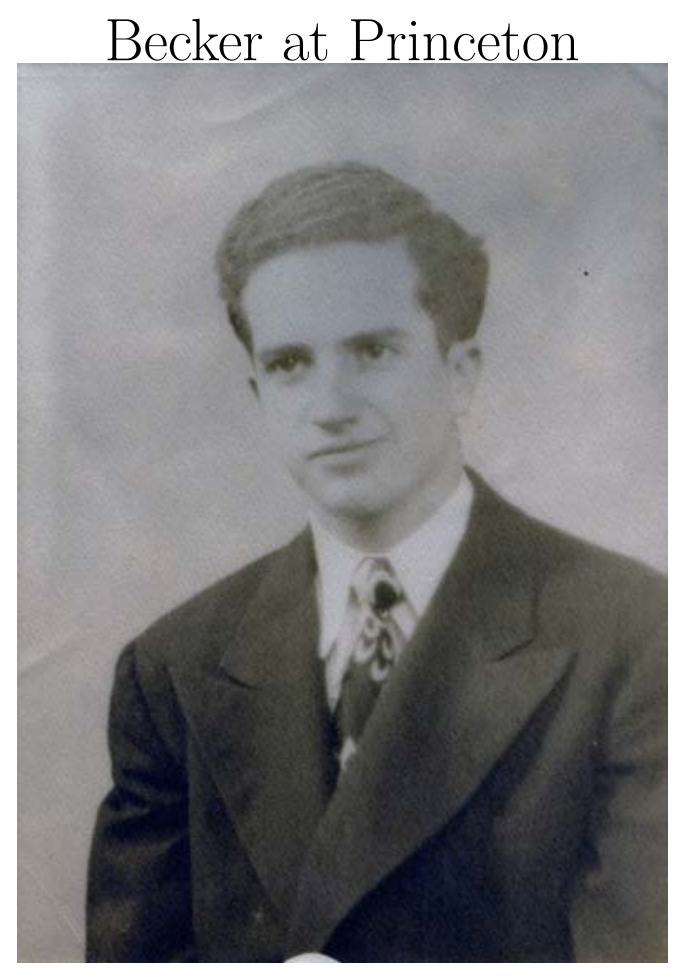


5. He took his interest in math to college. At Princeton was interested in being a math major.

(a) Roommate - John Milnor; later famous algebraic topologist;

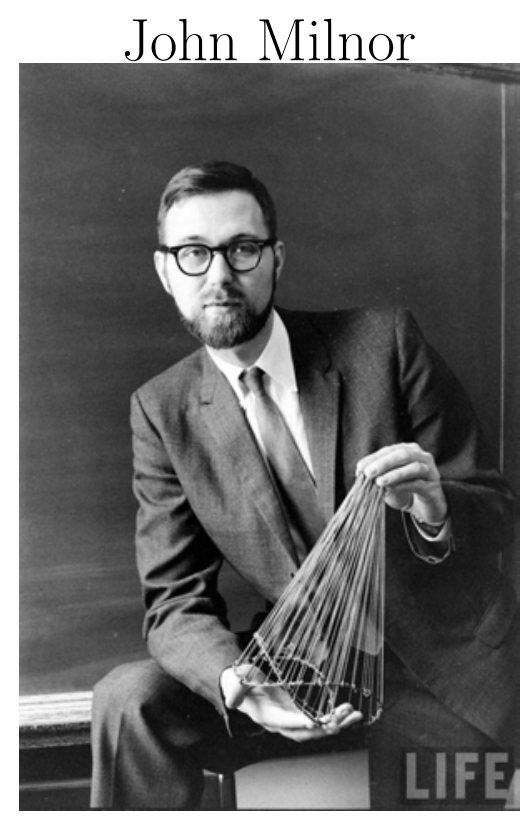

(b) As relayed to me in conversations over the years, Gary compared his skills with those of Milnor, who became a Fields medalist who later did fundamental work in algebraic topology.

(c) Fortunately for economics, his private application of the principle of comparative advantage led him to choose economics. 
(d) While an undergraduate, he drifted away from formalism in economics - flirted with sociology and Talcott Parsons.

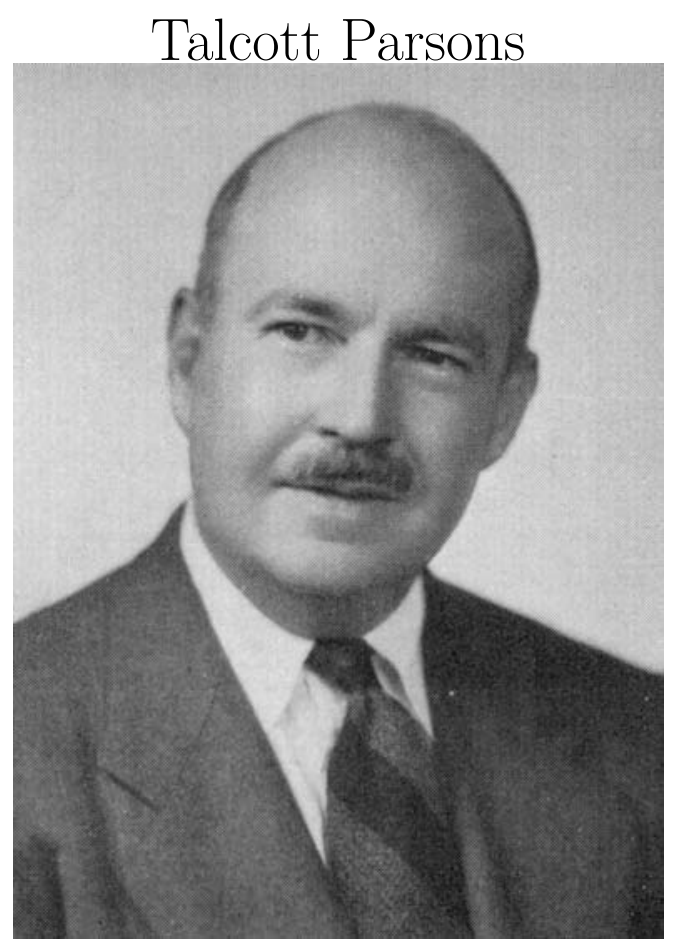

Writes that sociology was too hard and that Parson's jargon made it too hard for him (and everyone else) to understand. Again a wise choice. Some would say that Parsons was a king with no clothes.

(e) Graduated in 3 years. Wrote 2 papers as an undergraduate, published at age 21 . 

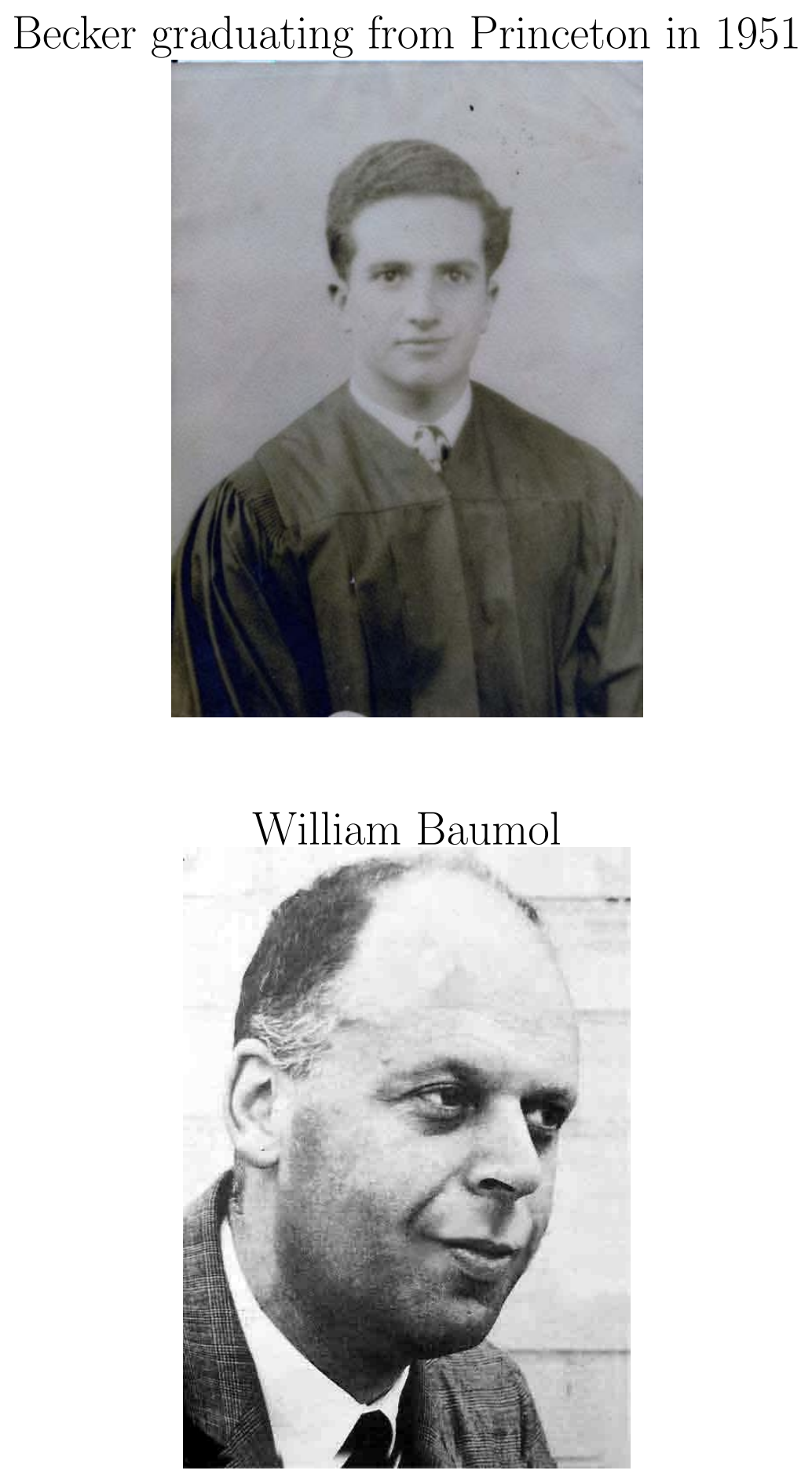
"The Classical Monetary Theory: The Outcome of the Discussion," with W. J. Baumol, Economica XIX (76): 355-76, November, 1952.

"A Note on Multi-Country Trade," American Economic Review, XLII (no. 4): 558-68, September 1952.

(f) Interacted with Viner on international trade in his senior thesis.

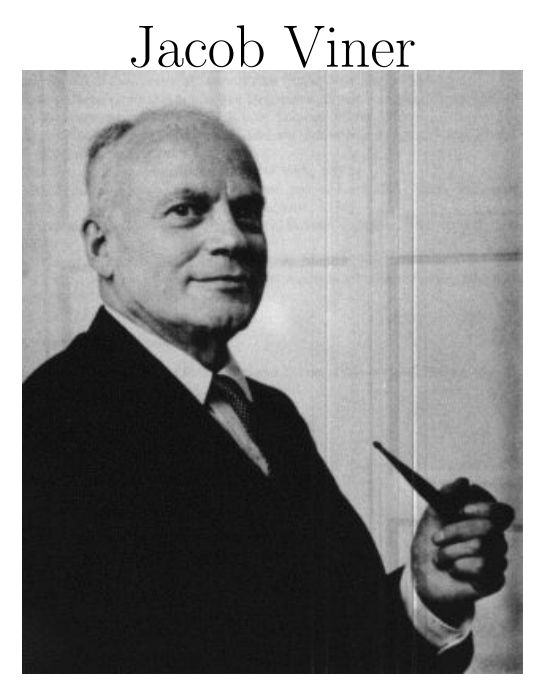

"Becker is the best student I ever had." 
(g) Viner's legendary letter on Becker to Chicago:

(In context, this is surprising since Viner taught Friedman, Stigler, and Alan Wallis!)

Others wrote to similar effect.

Choose between going to graduate school between Chicago and Harvard. To our great fortune and that of all economics chose Chicago and forged tight intellectual bonds between himself and Milton Friedman and himself and others at Chicago.

(h) This decision was momentous for Becker, for Chicago, and for economics.

Chicago of the 1950's: A place where the intellectual tectonic plates met and created both stress and uplift. Cowles Commission Econometrics and Theory along with price theory of Friedman and colleagues and, by and large, the two groups exchanged ideas, sometimes with great vehemence. Gary often tells of how he came to Chicago full of himself 
as a Princeton hot shot with 2 papers published and got the stuffing knocked out of him by Milton Friedman. But that jolt only intensified his desire to succeed, and he relished and learned from his interactions with Milton Friedman. 


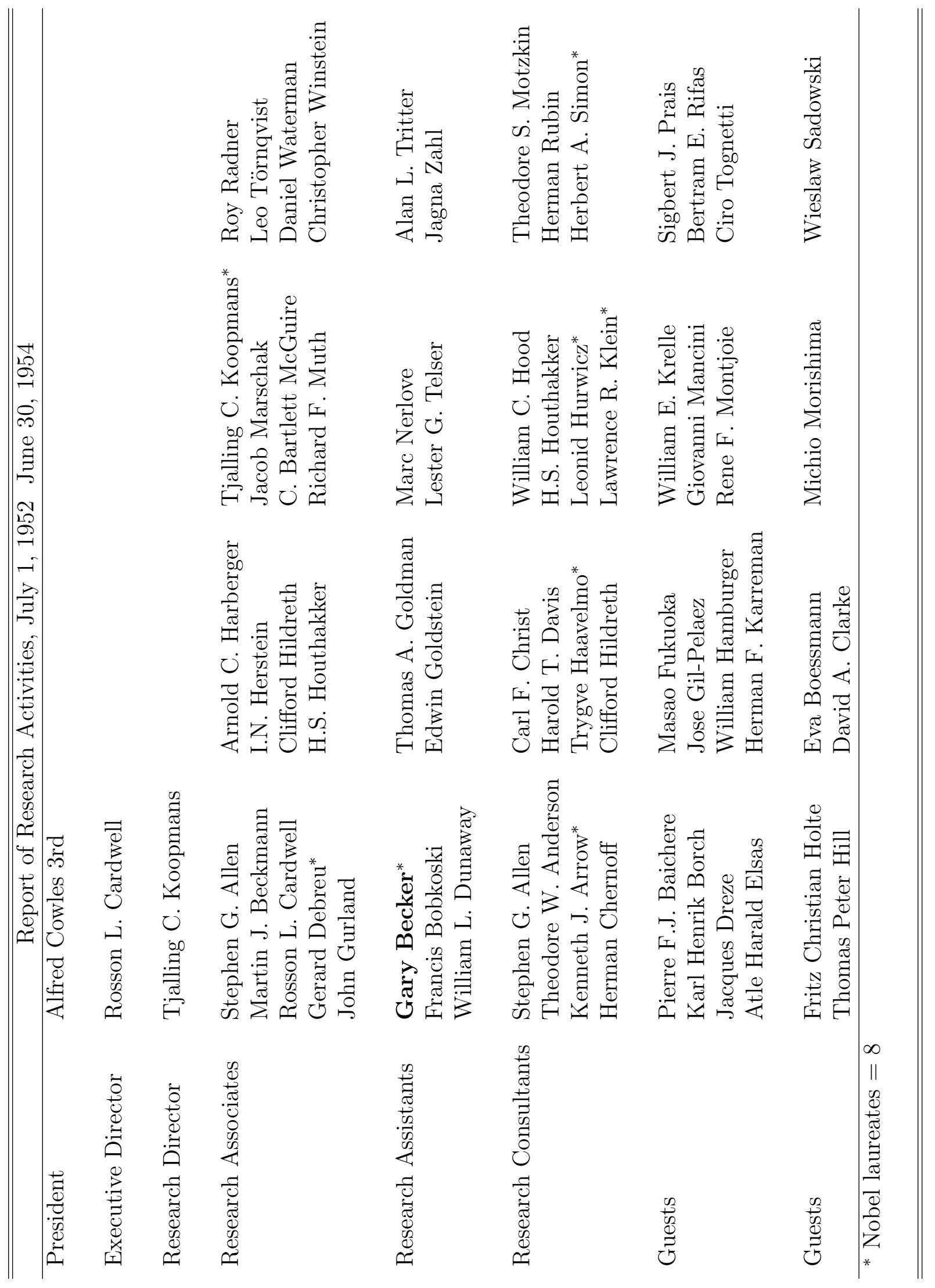


Selections from the Cowles Roster

Exterior of Cowles Building: Social Science Research

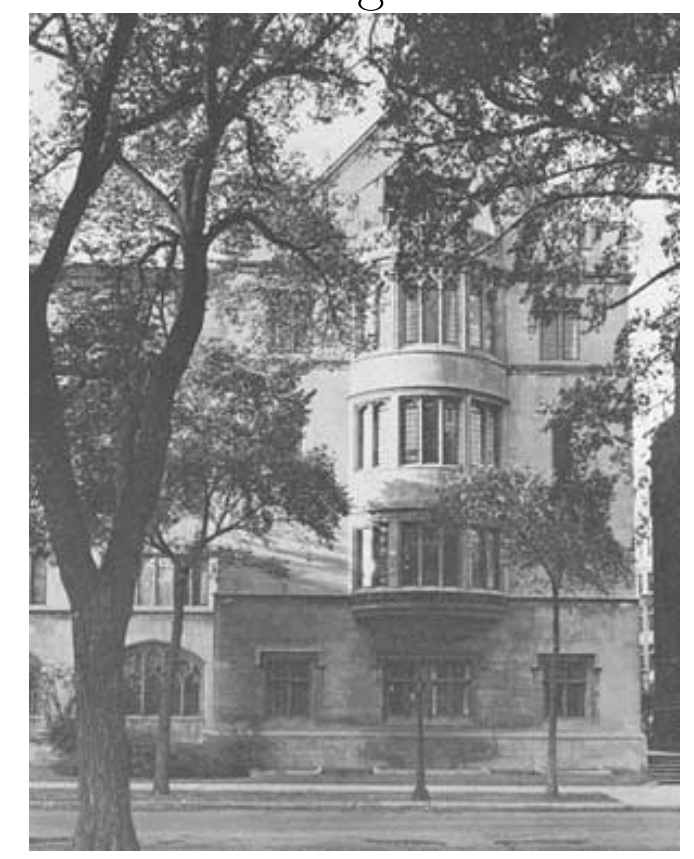

"... [W]hen you cannot measure, your knowledge is meager and unsatisfactory..."

- (Kelvin, 1883, as enshrined on the Social Science Research Building)

Motto of The Cowles Commission: Science and Measurement (which was later changed to "Theory and Measurement") 
The study of peer effects is now a hot topic in economics. A study of the productivity of the Chicago environment at that time and its effects on all those present would make a great case study.

Becker — open to experience — took it all in, and like a fish in water, swam in the currents and cross-currents streaming at Chicago at that time. 

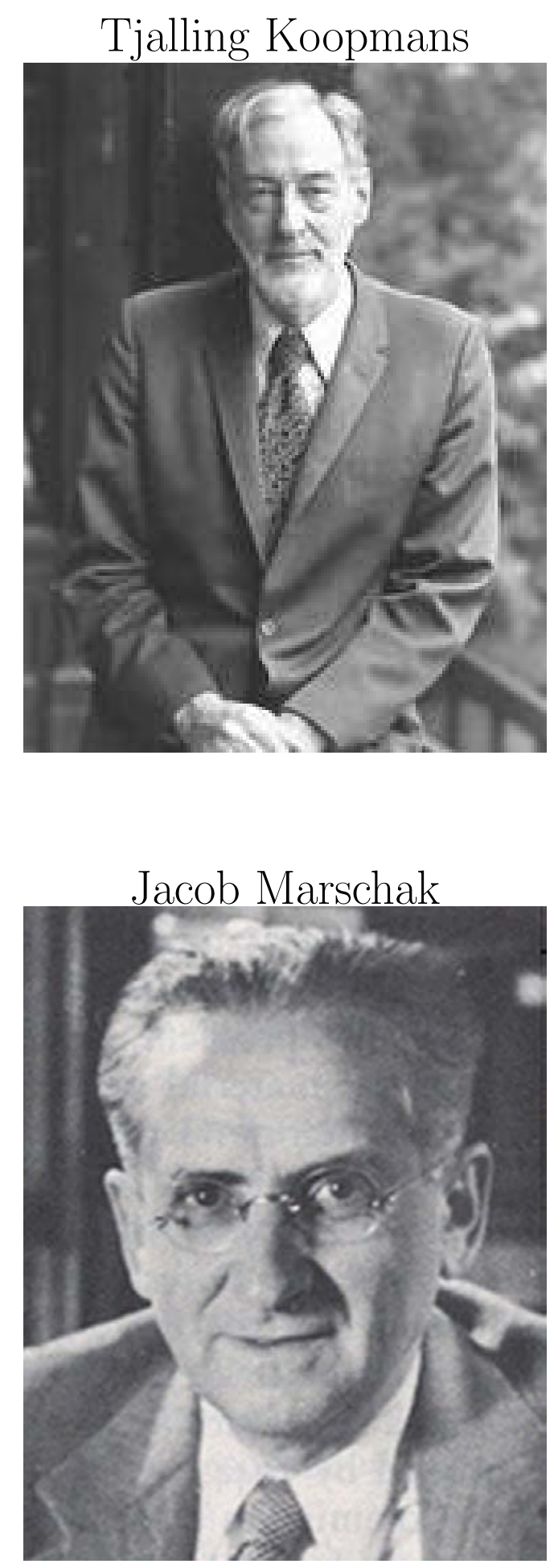

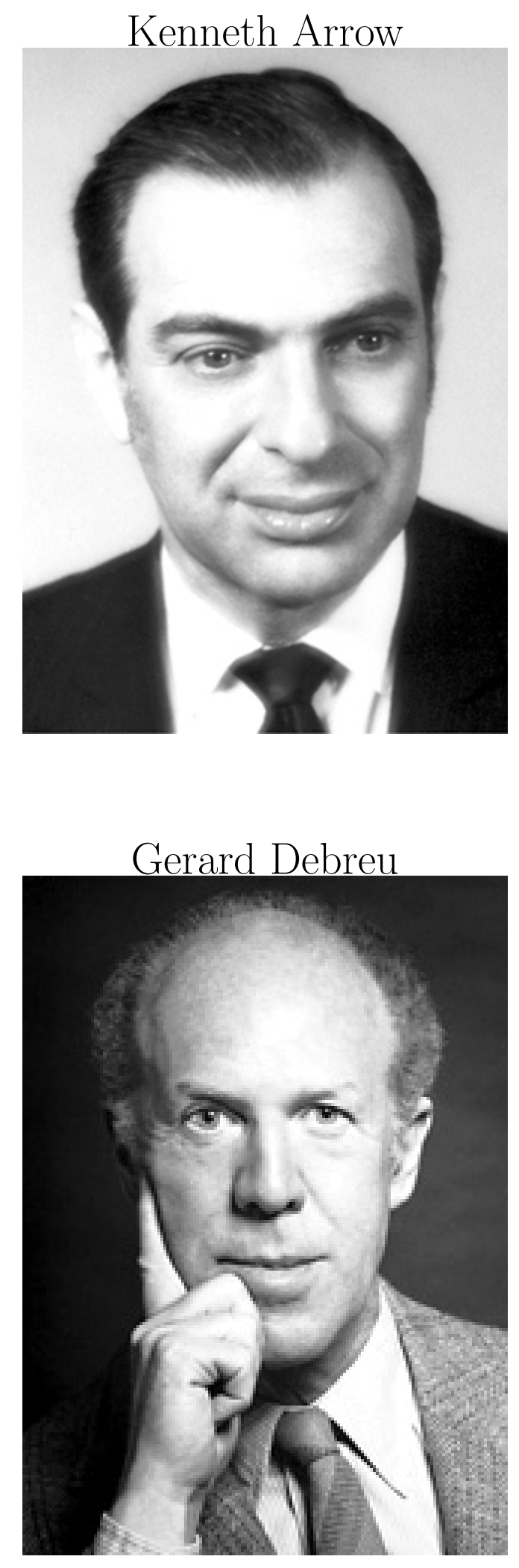
Leonid Hurwicz

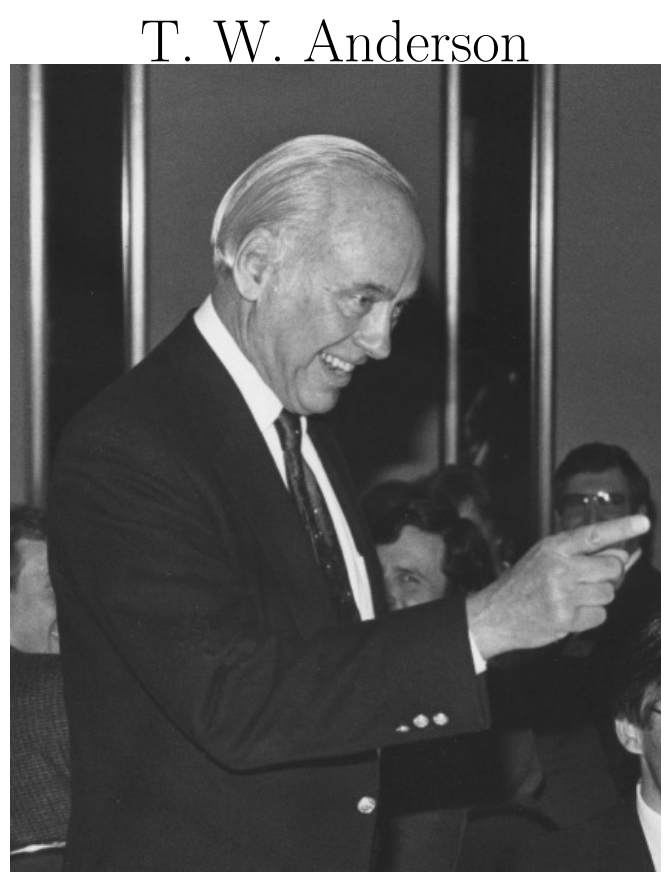




\section{Link to Statistics}

Jimmie Savage: Statistician and Coauthor with Friedman and

Opponent of Cowles Econometrics

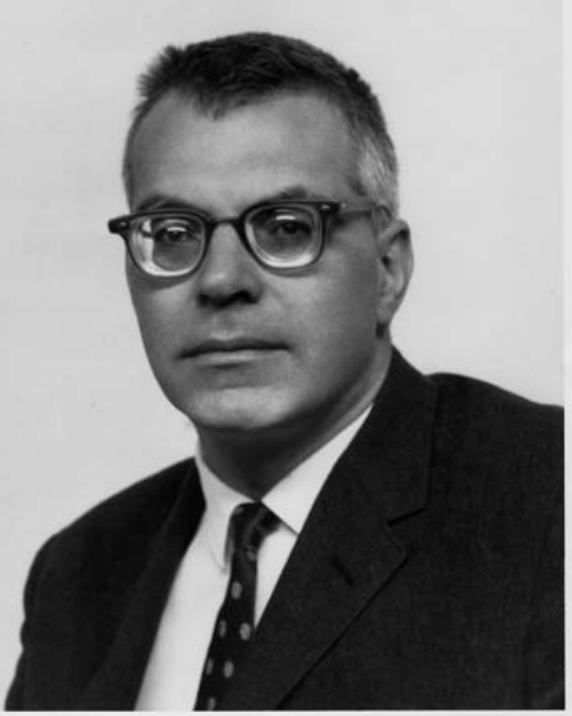




\section{Department}
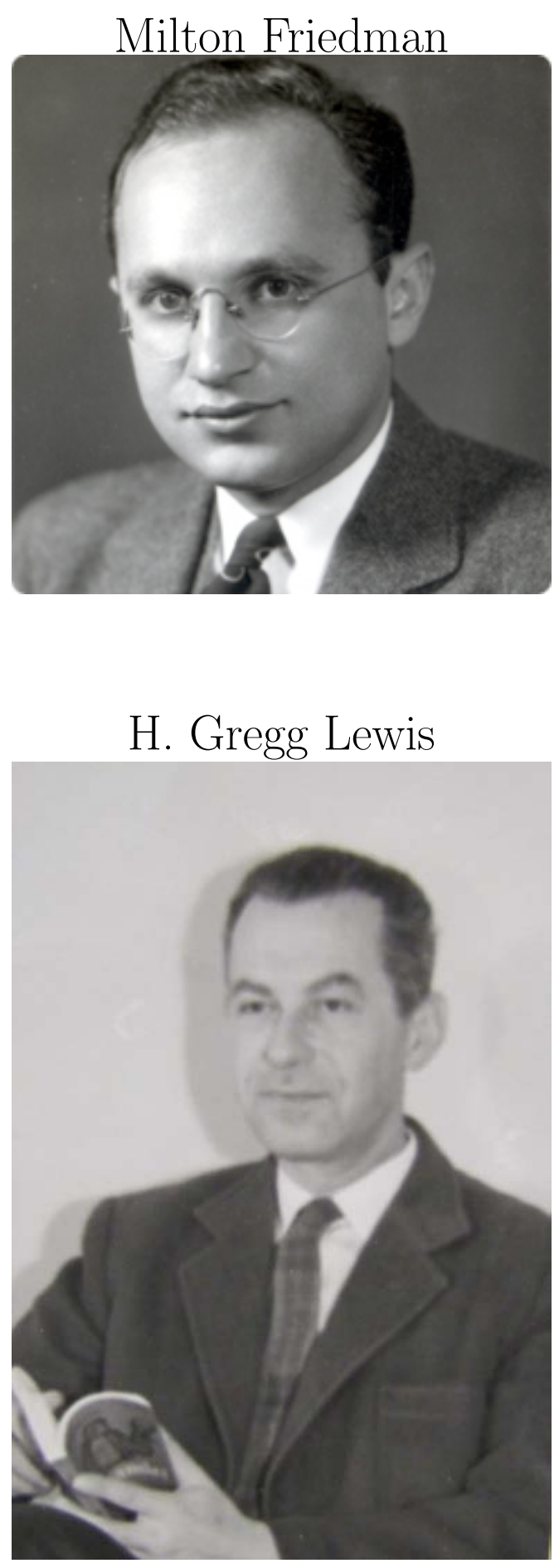

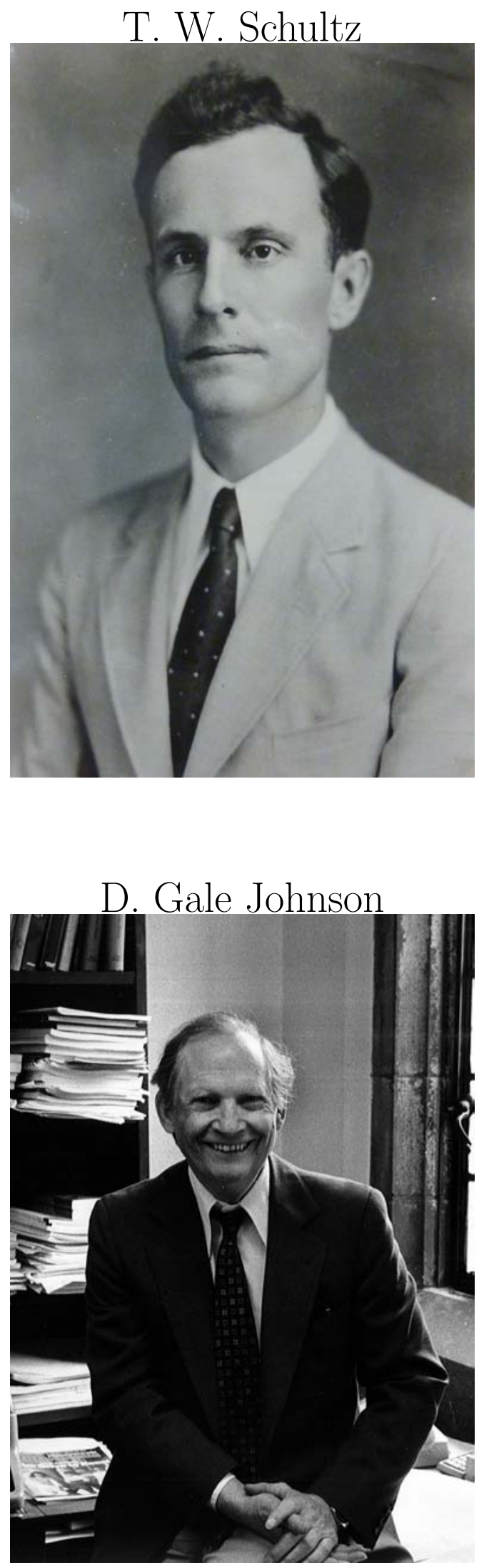

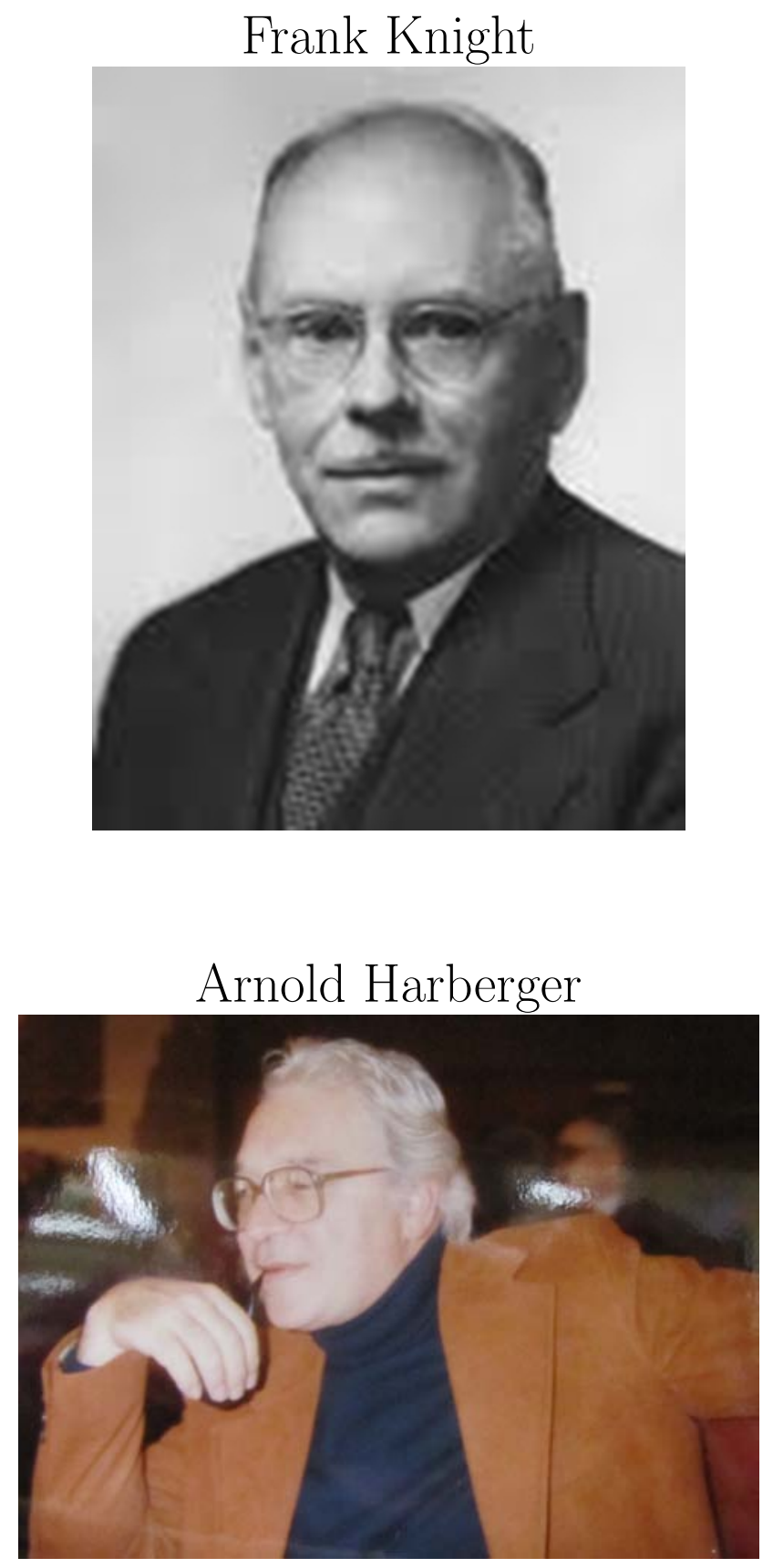


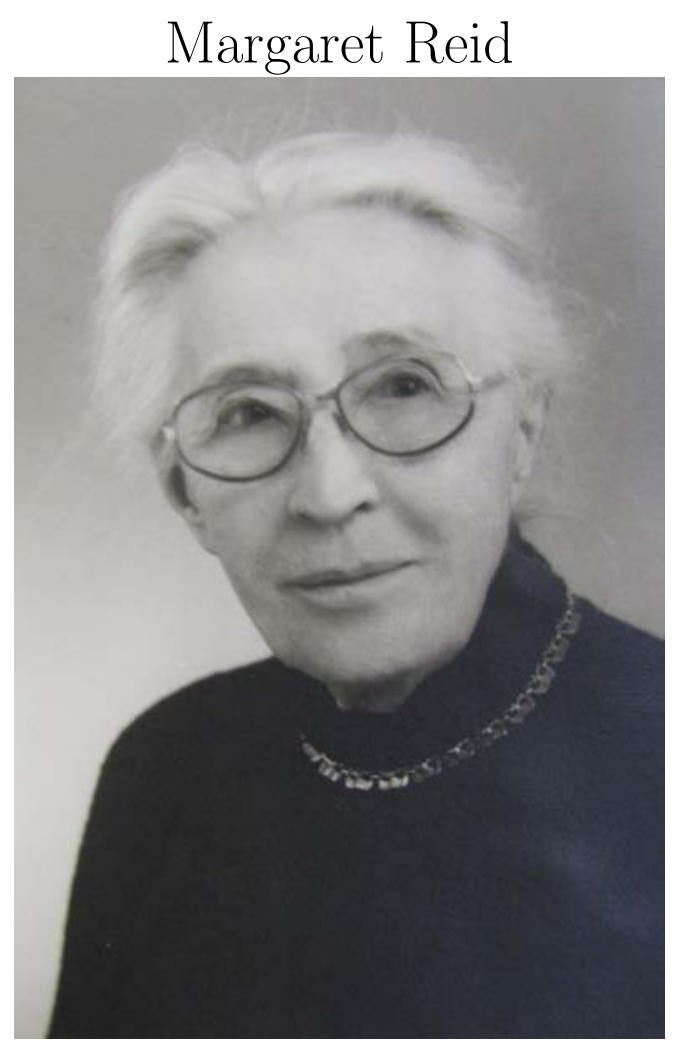


Fellow Students and RAs
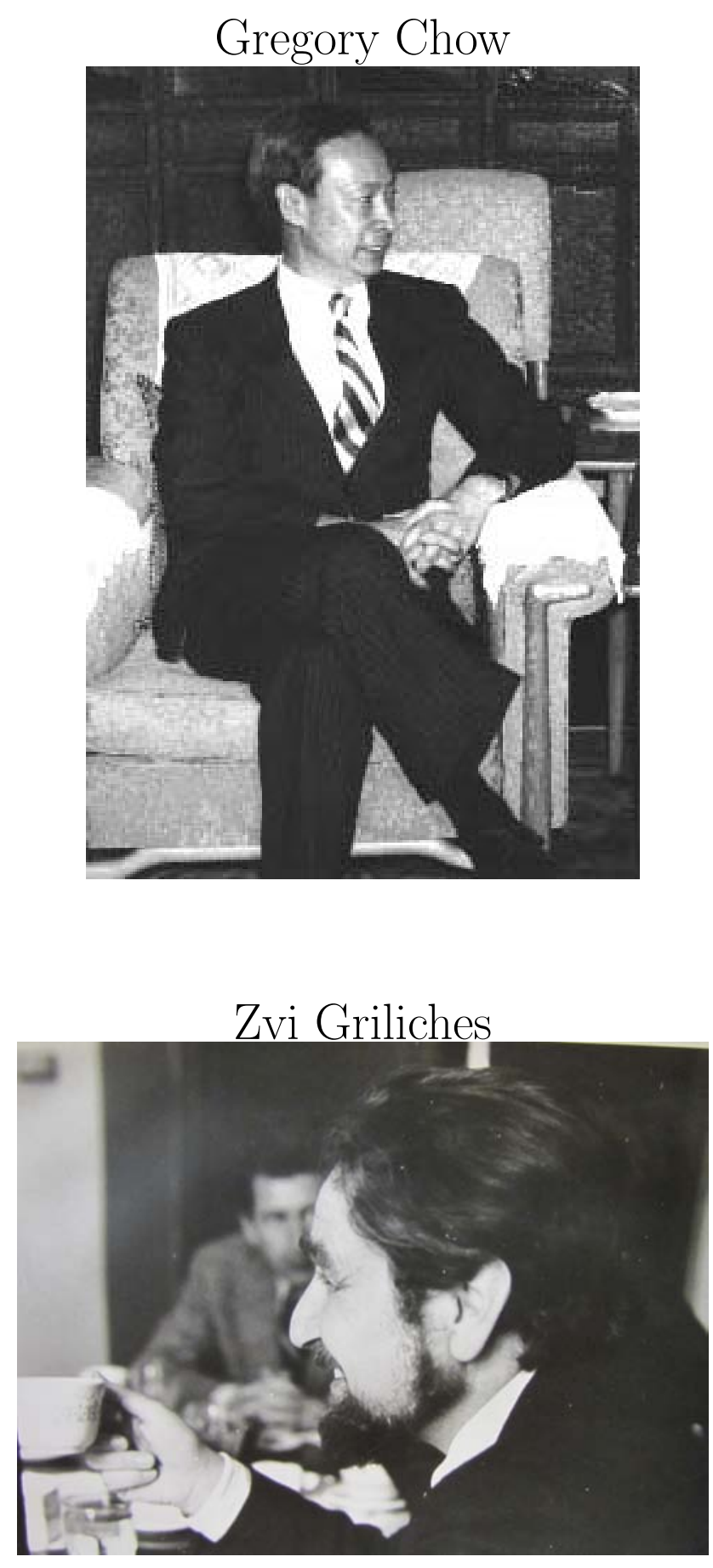

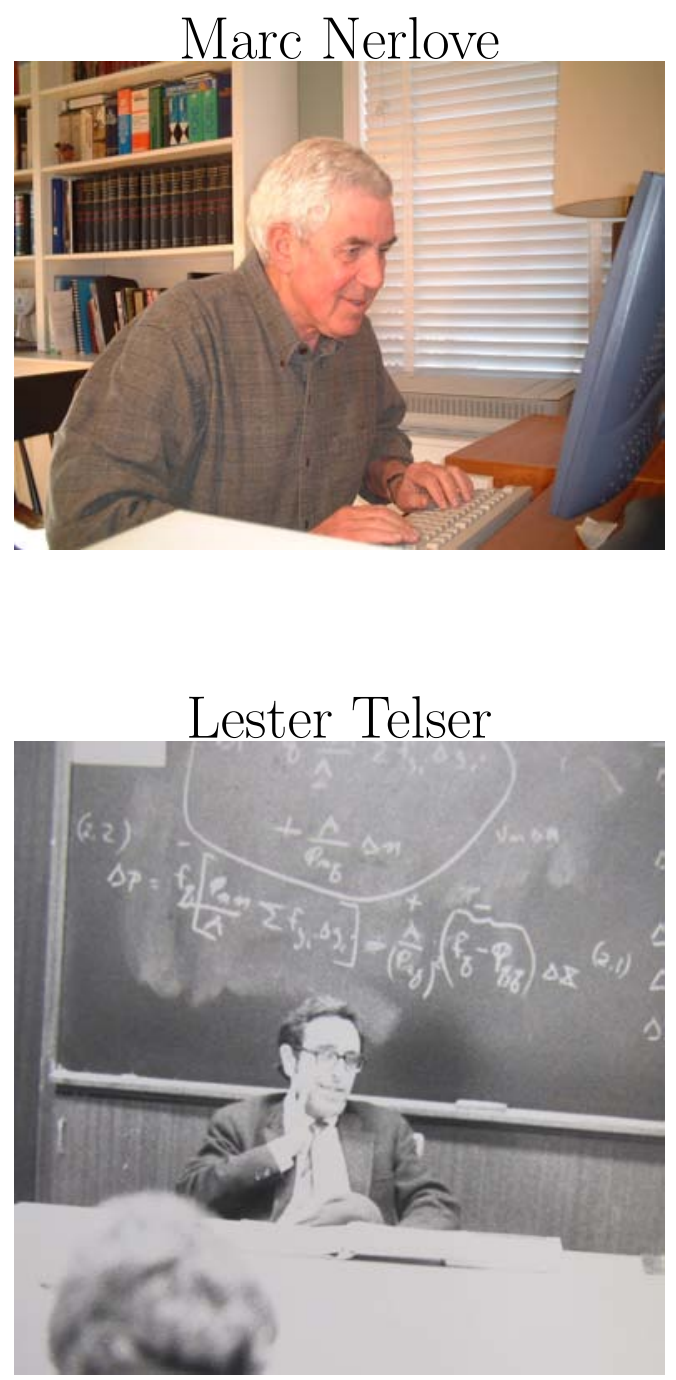
Roy Radner (Degree in Statistics)

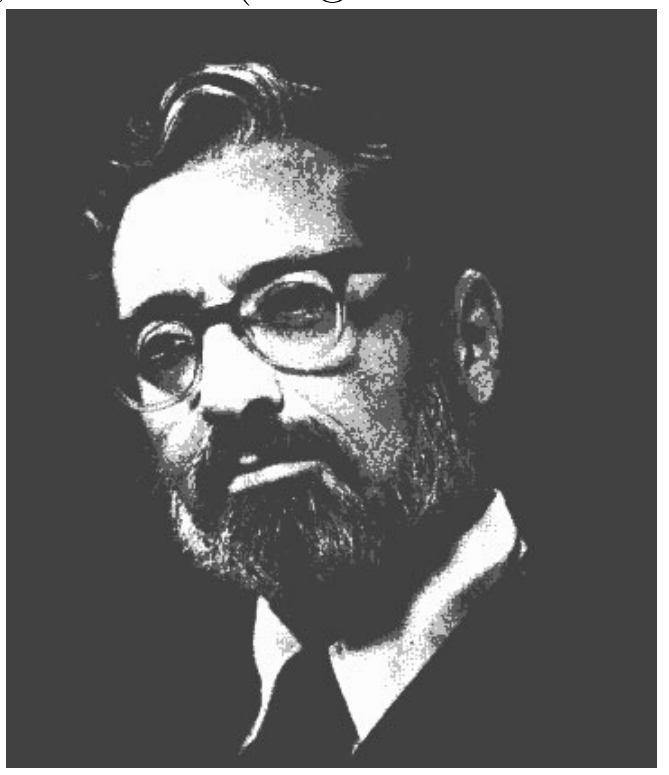




\section{Law School: (Legendary Director-Levi Workshop)}

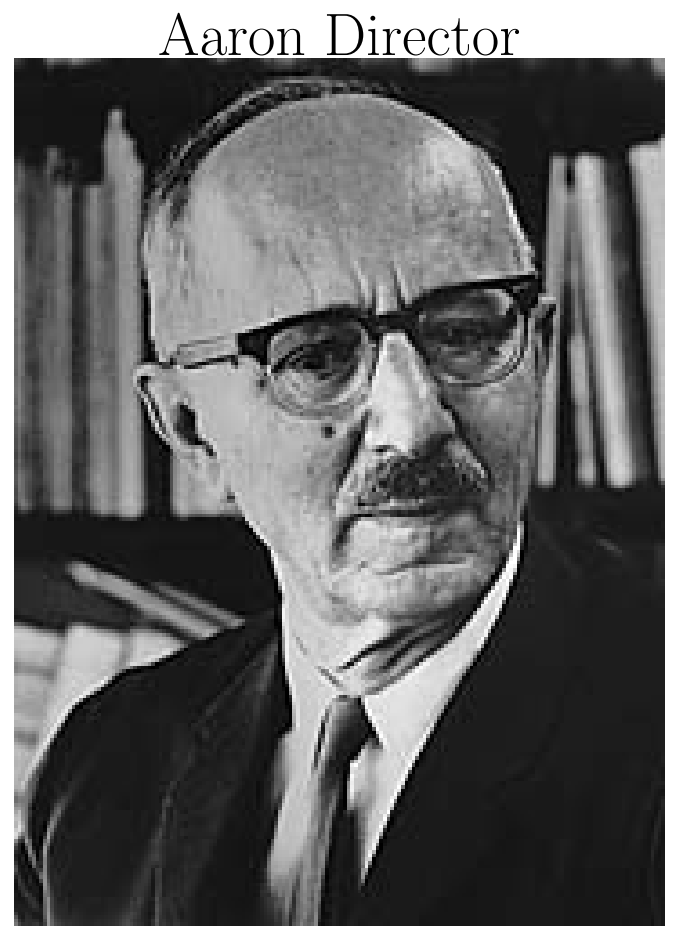

Edward Levi

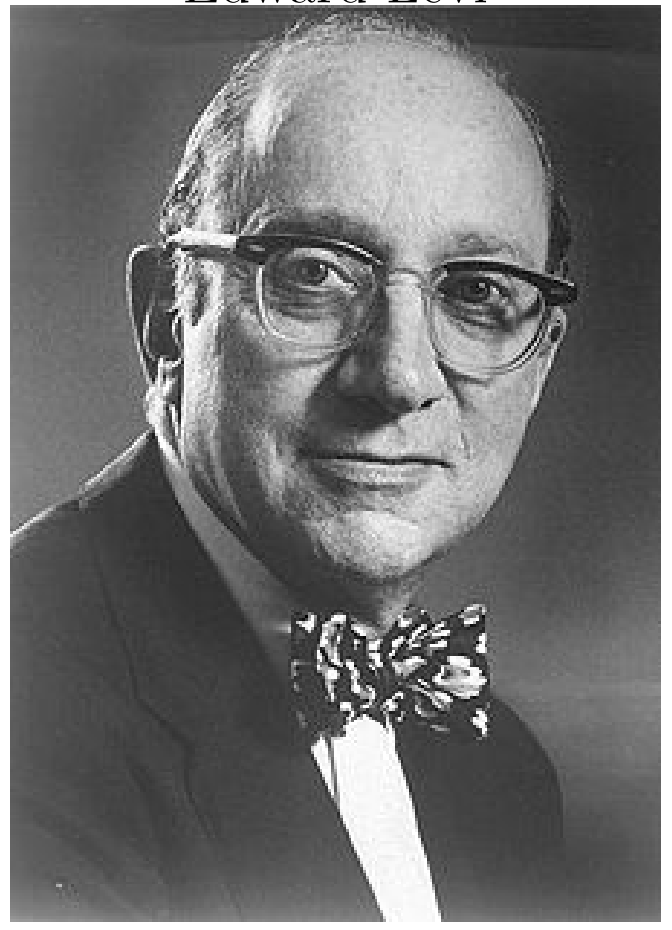


Committee on Social Thought and Interdisciplinarity

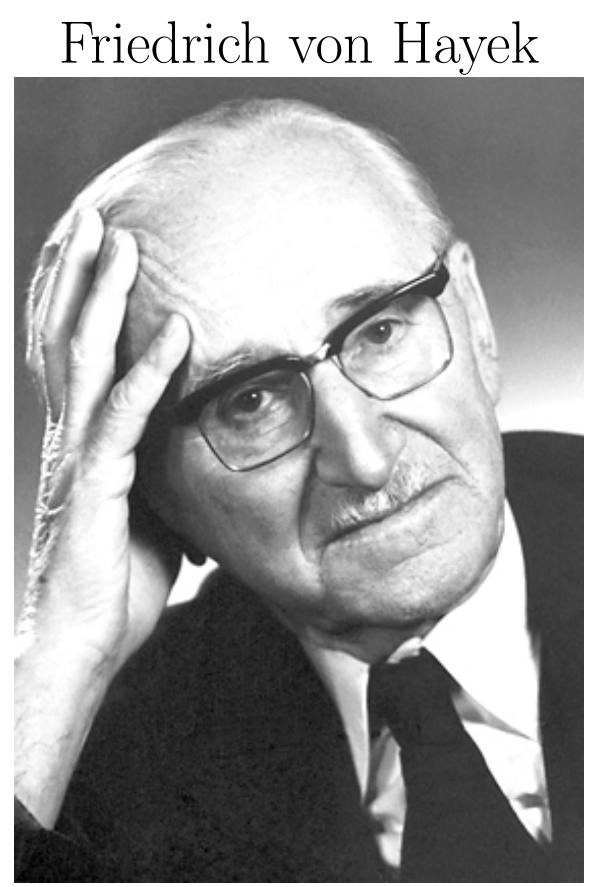


Measurement and Science Were Foremost on the Minds of Many at Chicago — Not Just the Economists

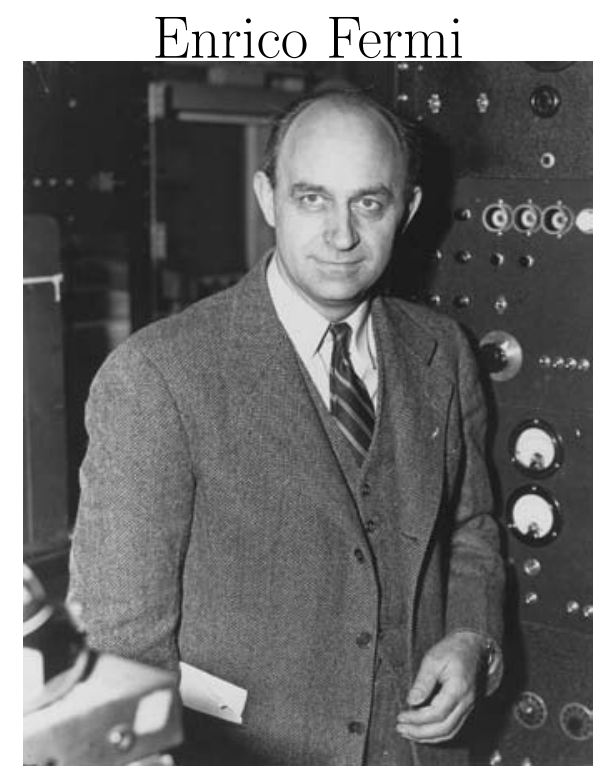

"Measurement is the making of distinctions, and the finer the distinctions, the finer the measurement." - Enrico Fermi at the Hayek Seminar 


\section{Becker at Chicago as a Student}

1. In three years got a Ph.D. (started as an assistant professor here).

2. Early on he had emerged as a formidable economist. Milton Friedman to James Kennedy of the Earhart Foundation, January $27,1953$.

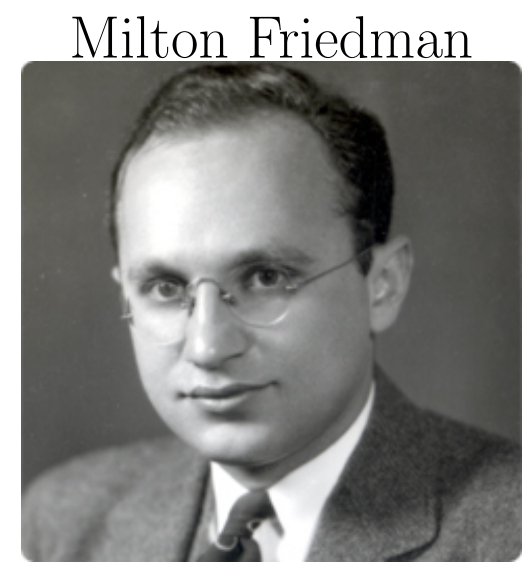

Friedman forecast what he was to say about Gary Becker 50 years later

"Gary Becker is a young man who received his A.B. from Princeton. He was recommended to us by his Princeton teachers for a departmental fellowship in terms that we found hard to take seriously - the 
best person that we have had in the last ten years; the best student that I have ever had, and the like. After observing him closely for the past year and a half, I am inclined to use similar superlatives: there is no other student that I have known in my six years at Chicago who seems to me as good as Becker or as likely to become an important and outstanding economist. Though only twenty two years old now, Becker has already published one paper in the American Economic Review and has collaborated with one of his teachers at Princeton in a paper published in Economica. Both are first rate papers. Becker needs to do one more full year of graduate work to fulfill his requirements for his Ph.D."

"Becker has a brilliant, analytical mind; great originality; knowledge of the history of economic thought and respect for its importance; a real feeling for the interrelationships between economic and political issues; and a profound understanding of 
both the operation of a price system and its importance as a protection of individual liberty. This is one of those cases in which there is just no question at all about Beckers being preeminently qualified for one of your fellowships. I wish I could look forward to being able to find a candidate this good every year, but that is asking for too much." 
3. Presented thesis proposal after 2 years in residence. Defended after 3 years.
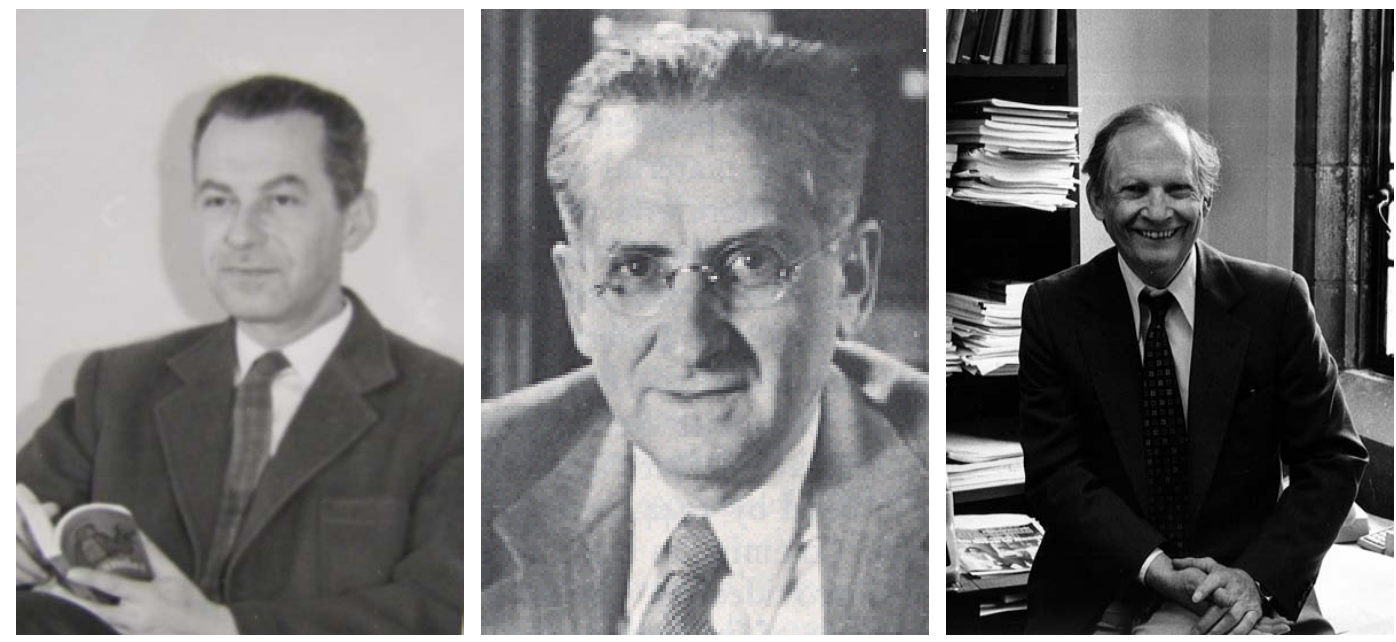

Thesis Committee for Economics of Discrimination.

H.G. Lewis Chair, J. Marschak, D. Gale Johnson and William Bradbury (sociologist)

Becker as a Grad Student at Chicago

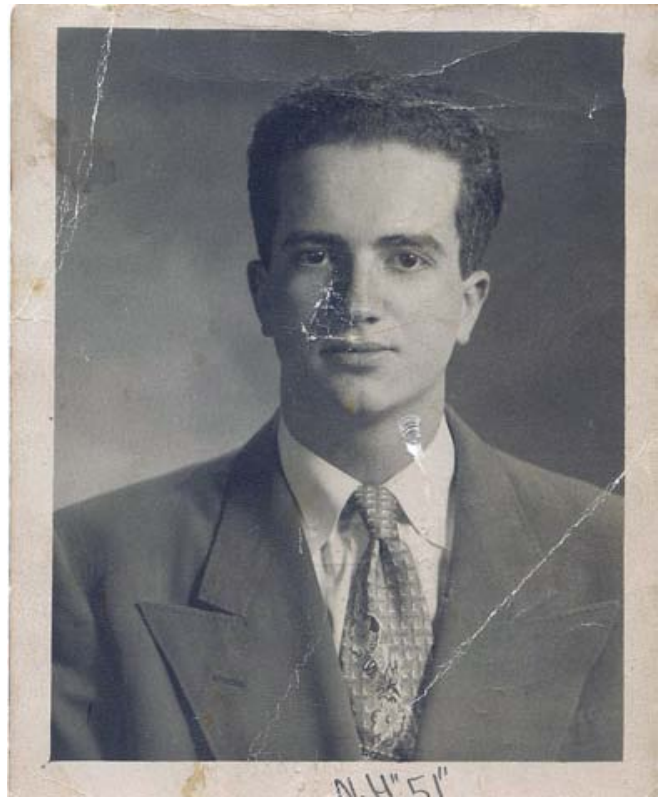




\section{Economics of Discrimination: Ph.D. Thesis}

Why did he choose this topic? Had he personally experienced discrimination? I do not know.

The thesis was a remarkable feat.

Recast Discussion of the Problem, Which Up to That Point Was the Province of Psychologists and Sociologists:

(Gordon Allport: Nature of Discrimination)

(a) Defined Market Discrimination in an Empirically Operational Way - Price People Pay for their tastes

(b) Showed which groups benefited and which lost from discrimination. The great benefits of trade and the likely costs of withdrawal of groups from society, e.g., as proposed by the Marcus Garvey movement.

(c) Came up with market equilibrium (Market versus Individual Discrimination)

Highly relevant for audit pair studies today that sample the average transaction, not the transaction at the margin. 
(d) Explained how greater numbers in some regions led Blacks to deal with more discriminatory individuals (at margin they get lower wages)

(e) Distinguished analytically, segregation from discrimination

(f) Interpreted a wide range of facts with the model. Did original empirical work on the time series of the status of blacks. (A trait that was in the spirit of Friedman's work on the consumption function.)

(g) Tested the theory on a variety of data in the Spirit of the Methodology of Positive Economics (which was being written when Gary was a grad student).

(Measurement is an ongoing theme of Chicago and of Gary Becker.)

Contributions of the Book:

(1) Pioneered utility maximizing model of firm (prior to Williamson and Baumol). 
(2) Introduced heterogeneous preferences and market sorting and their implications.

(3) Created a framework for thinking about discriminationimplemented and tested (Landes; Ashenfelter; Charles and Guryan)

(4) Did not look at the origins of preferences.

(5) Showed how discrimination could persist with sufficiently in elastic supply and while highly original was not one of the pillars of his later work.

(6) While enough for most people, it's a minor work compared to his later achievements. 
Like John Hicks before him, started out life as a labor economist, and his research and the research inspired by his research reformulated and created a body of tools for the study of the labor market. Human Capital Revolution.

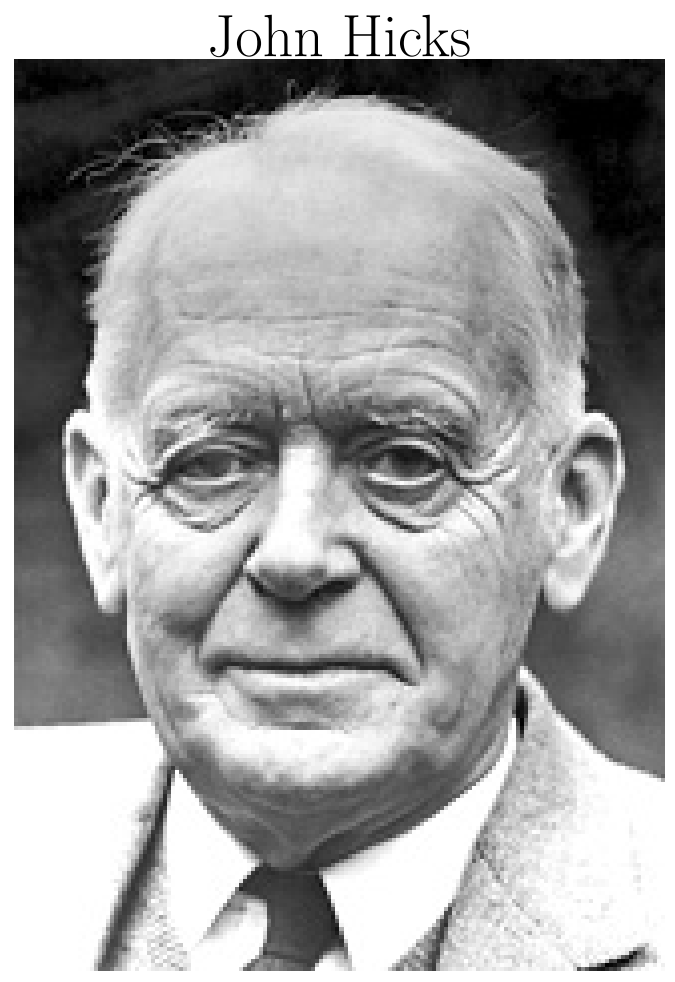


At that time, outside of Chicago (Lewis and Rees) and Stanford (Reder), labor economics was the province of industrial relations, negotiators and bargaining experts, and descriptive empirical scholars. The one exception from an earlier era was Paul Douglas, who did basic pioneering work on labor supply and production. His colleague, Henry Schultz, helped create the empirical methodology of demand and supply analysis that used

Paul Douglas

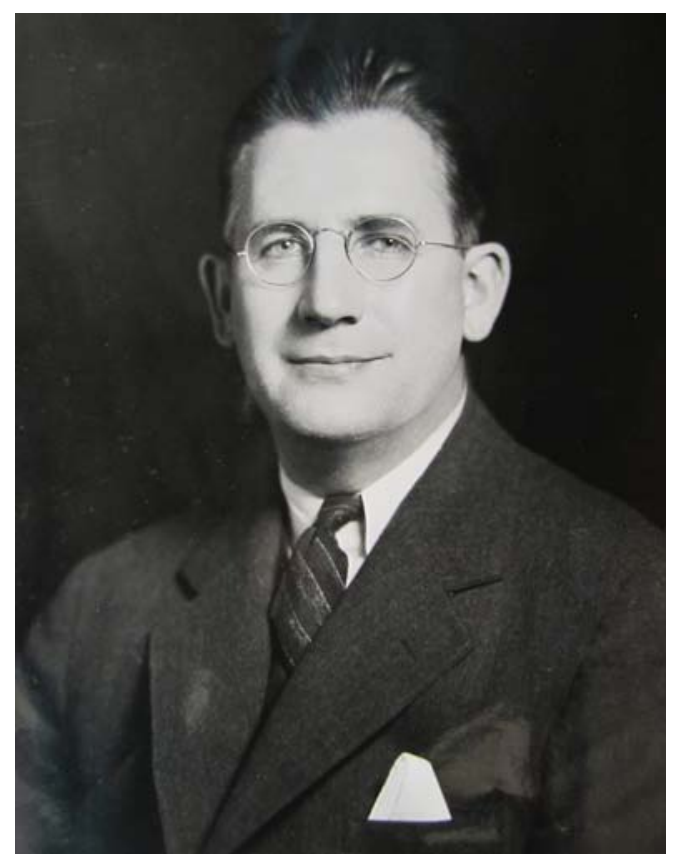

Henry Schultz

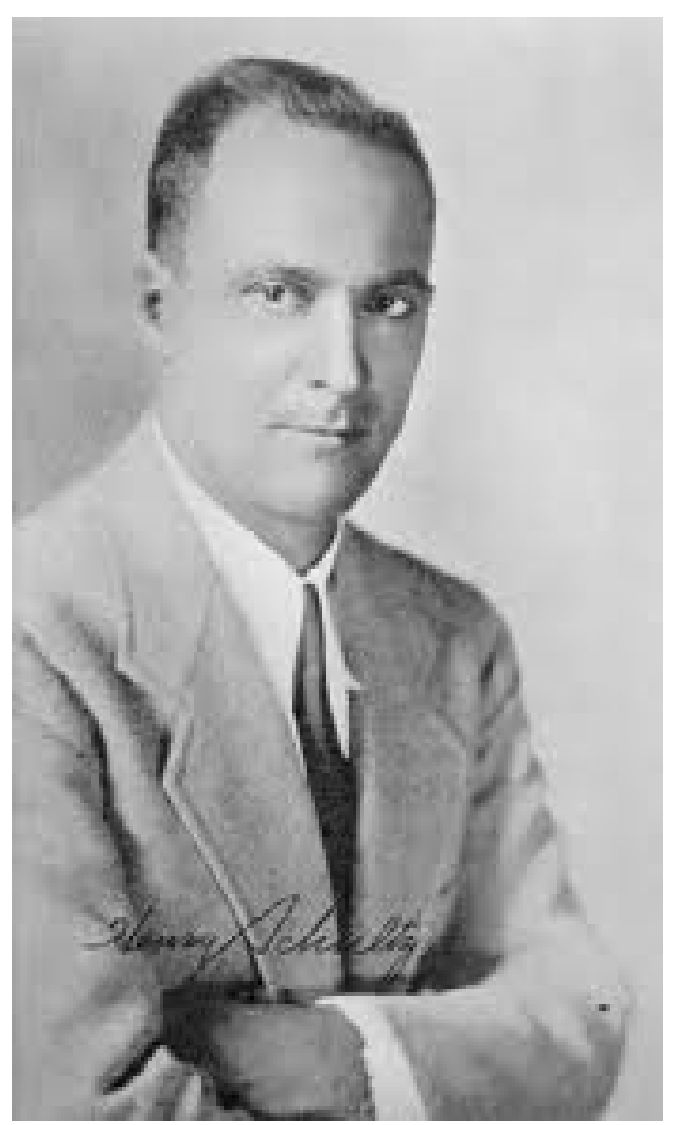


The quality of the work in labor economics in the 1940s and 1950s was vastly different from what it now is today. Then it was a body of facts with no interpretation or theory.

Becker helped change all of that. 
A Field of Analytical Labor Economics Was Emerging at the Time Gary Was a Student
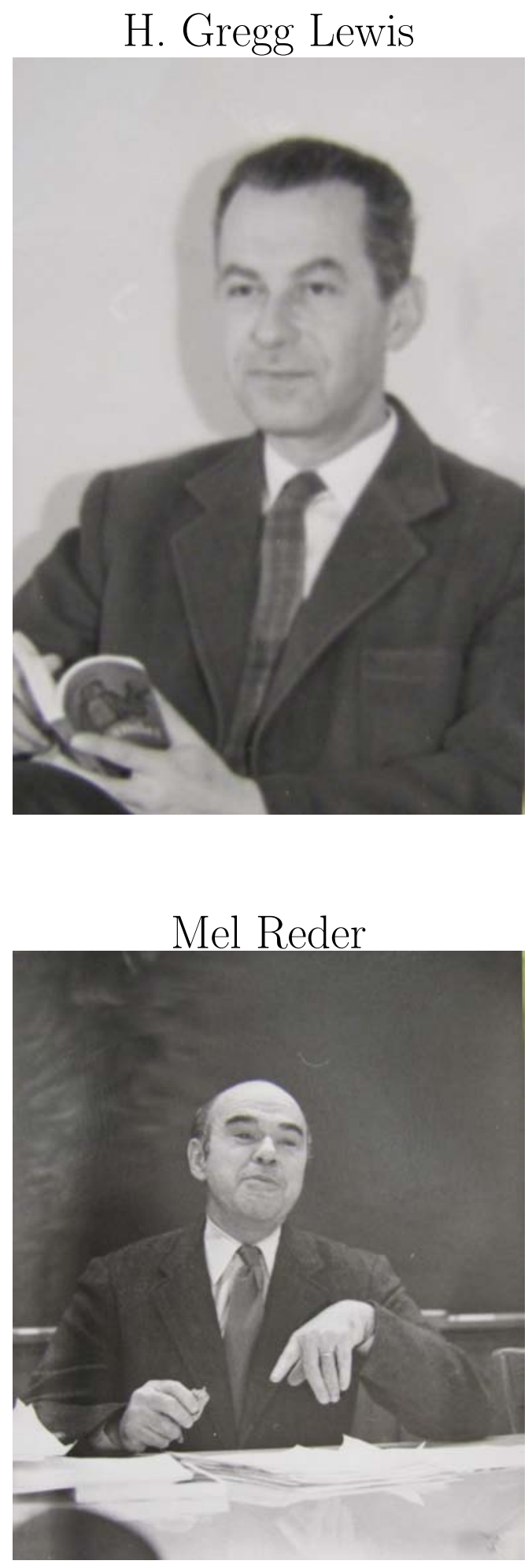


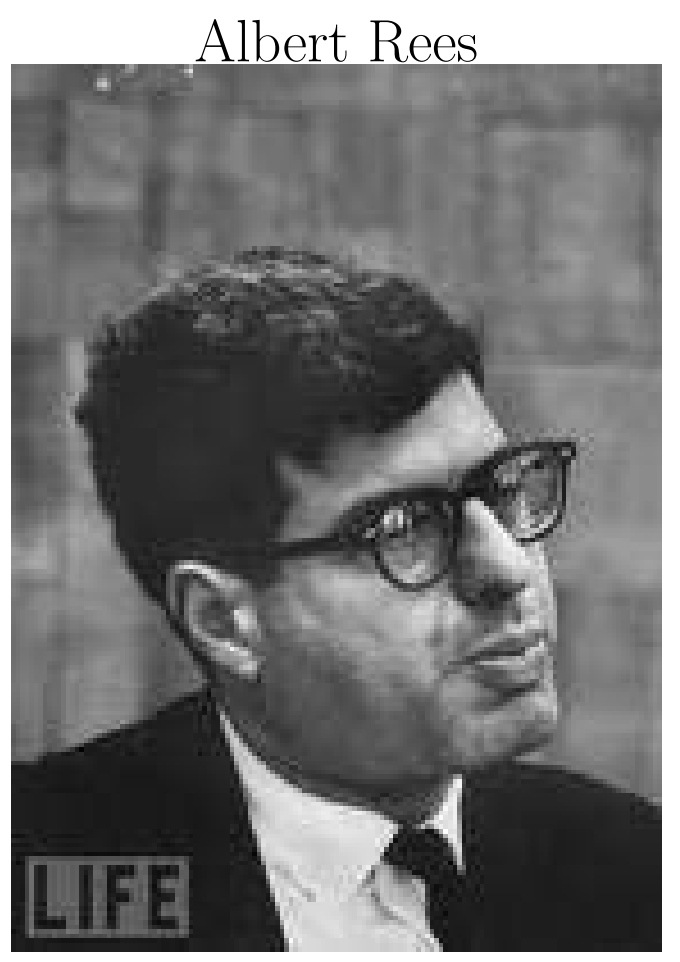

4. When he went on the job market, T.W. Schultz (chair and future Nobel laureate) wrote the following in January 25, 1956 (letter to Seymour Harris at Harvard): 


\section{T. W. Schultz}

Seymour Harris
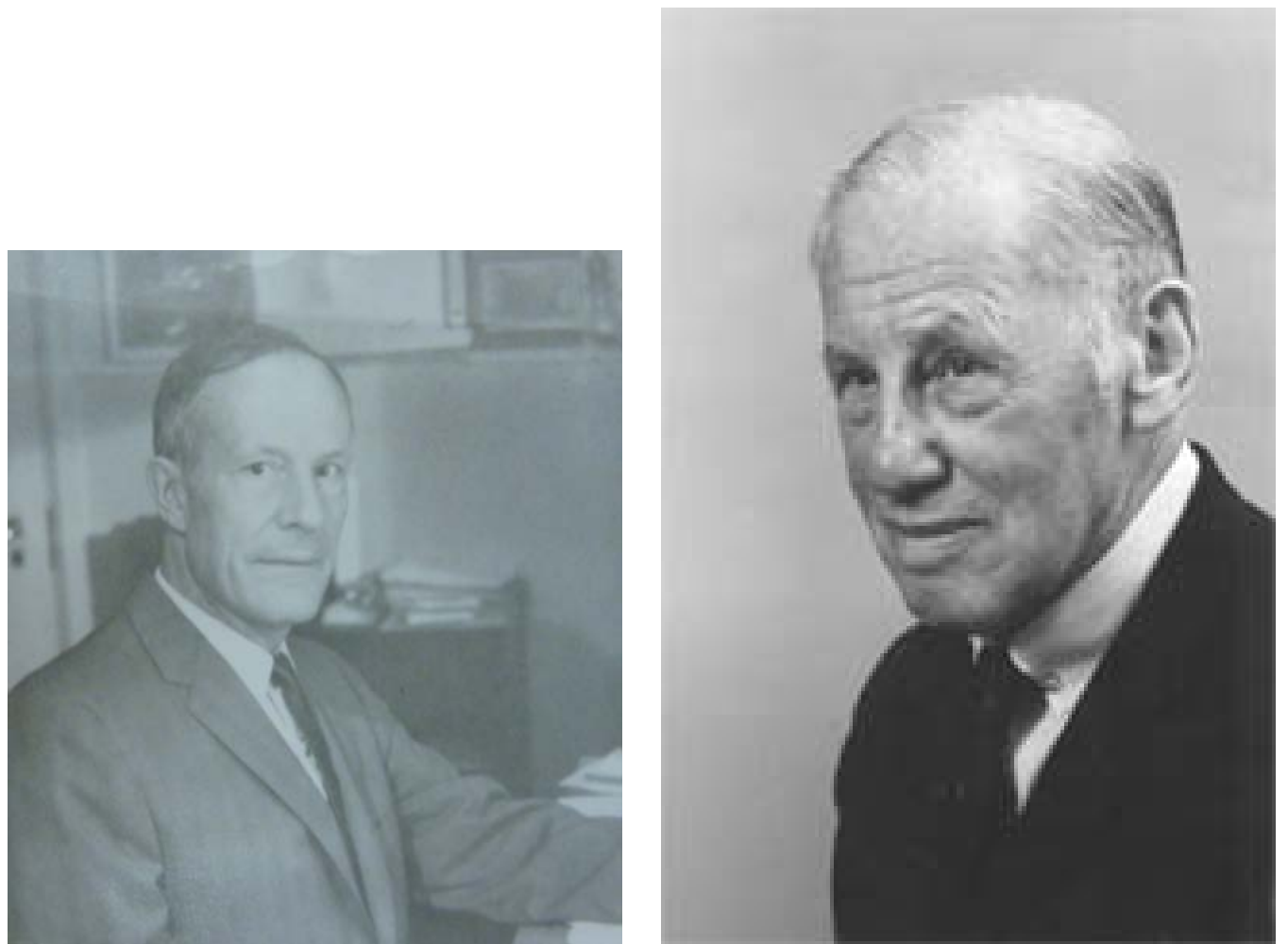

"Gary Becker is as good as they come at that age. He has unusual analytical power and he has learned how to use it. He is so much better than most graduate students and the run of Ph. D's that one has to compare him with men like Kenneth Arrow. With the evidence we now have, he is in Arrow's class in analytical power, his command of tools, both economic theory and statistical inference, and in his sense of relevance. Moreover, he 


\section{has a taste and a desire to do empirical work."}

"Also he has every indication of being a successful teacher with great clarity, tolerance, and again a sense of relevance."

"He is assured of an assistant professor ship here next year. This is at $\$ 6,000$ [ $\$ 48,000$ in 2010 dollars] and he would have half or more of his time for research, for his teaching load would be very light indeed. We would ask him to teach a bit of advanced theory but it would take a small fraction of his energies and time. His longer run professional interests would distinctly be served by establishing himself in another academic environment as he has done here. He has been seriously considering because of his great desire to do research and also to broaden his experience taking an appointment at the National Bureau. Fabricant has been after him to do this. A post with you, provided that his teaching duties are not burdensome - not above one half his time would certainly be to his academic interest."

"Again let me say, to the extent that I have 
insights on what is involved in distinguished work in economics, Gary Becker has all of the earmarks of coming through."

Letter from H.G. Lewis to H.J. Newman (Chicago Fed):

"This is in answer to your recent request for information about my colleague, Professor Gary Becker."

"I have known Becker very well throughout his entire residence in Chicago. He came here as a student, attended several of my classes, wrote his thesis largely under my supervision, and he and his wife are close friends of mine."

"It is hard to write to you about Mr. Becker without sounding overenthusiastic. He is an exceedingly intelligent and imaginative young man and certainly, I think, will become really outstanding in the economics profession. He is honest in all matters, has the highest character, and I am confi- 
dent, is exceedingly trustworthy. I recommend him to you without any reservations." - H. G. Lewis (1956) 


\section{At Chicago on the Faculty}

(a) Papers with Friedman

- "A Statistical Illusion in Judging Keynesian Models," with Milton Friedman, Journal of Political Economy LXV (no. 1): 64-75, February, 1957.

- "The Friedman-Becker Illusion: Reply," with Milton Friedman, Journal of Political Economy 66 (no. 6): 545-57, December 1958.

(b) Papers on Democracy

- Precursor to Downes work that came later and was more systematically developed.

- Rejected by JPE

- Knight had a normative theory of democracy

- Becker - a positive theory

- Becker was a positive economist under the influence of Friedman. 
(c) Early interactions with T. W. Schultz who was thinking about human capital and its importance in a broad way. 


\section{Traits Identified Early in These Letters and His Work}

1. Intelligence and Character

2. Integrity

3. Persistence

4. Creativity

5. Courtesy and respect for others (Agreeableness).

6. Knowledge of the history of economic thought and the ability and desire to place his research in the context of work that preceded his. A vision that he was preserving and extending a tradition. This has carried through in all his work. (History of economic thought used to be the way economic theory was taught.)

7. Interest in explaining facts and testing theories against the facts. (A student of the "Methodology of Positive Economics" which formalized a pre-existing Chicago empirical tradition- e.g., Douglas and Lewis.)

8. Autonomy and intellectual independence - nobody's boy. 
9. Becker was offered a permanent job at Chicago - he stayed on but left after 3 years in the faculty. Desired to prove himself on his own, and did he ever.

10. Showed amazing persistence and internal strength. Early on was placing his work in the context of the larger body of economic theory.

11. Never severed ties with Chicago - just went off on his own and developed his own identity. Chicago supported him — the early enthusiasm for him never chilled.

These traits were essential to the success of his career that we celebrate today. Question - How predictive were they? 
Saw the Value of Standing on His Own Two Feet-Sought Independence. Columbia and NBER

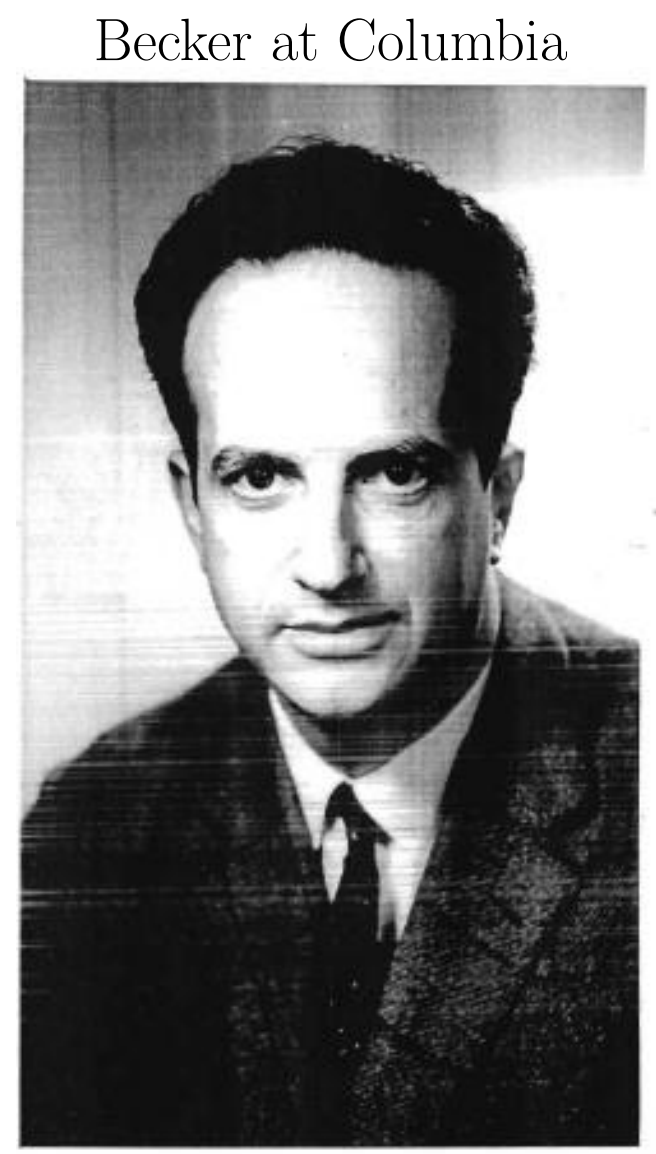


Partnership with Mincer at Columbia

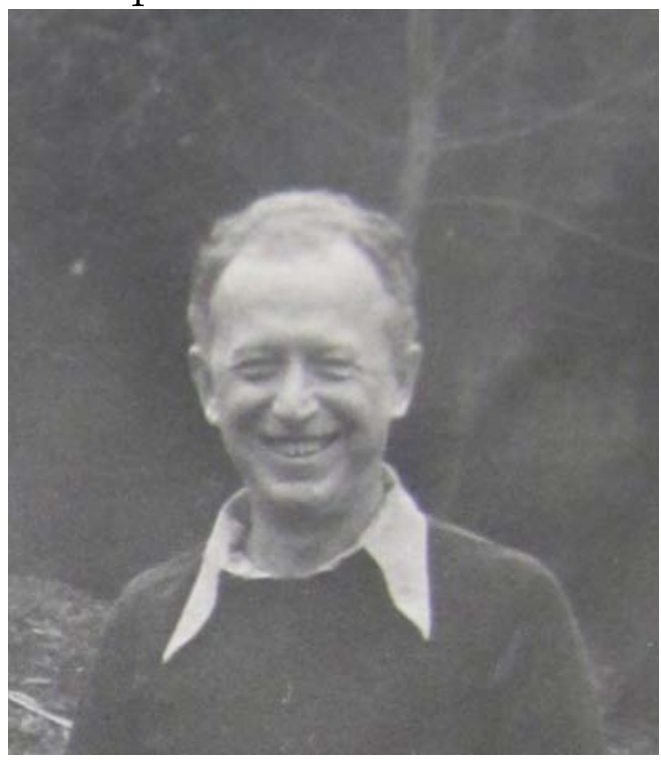

Colleague, William Vickery

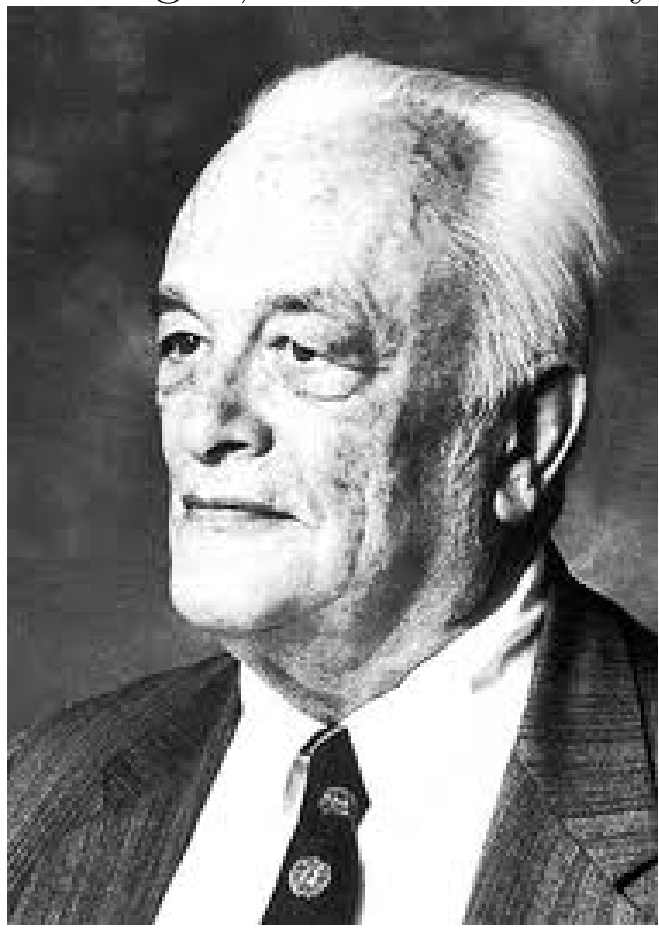


Colleague, Kelvin Lancaster

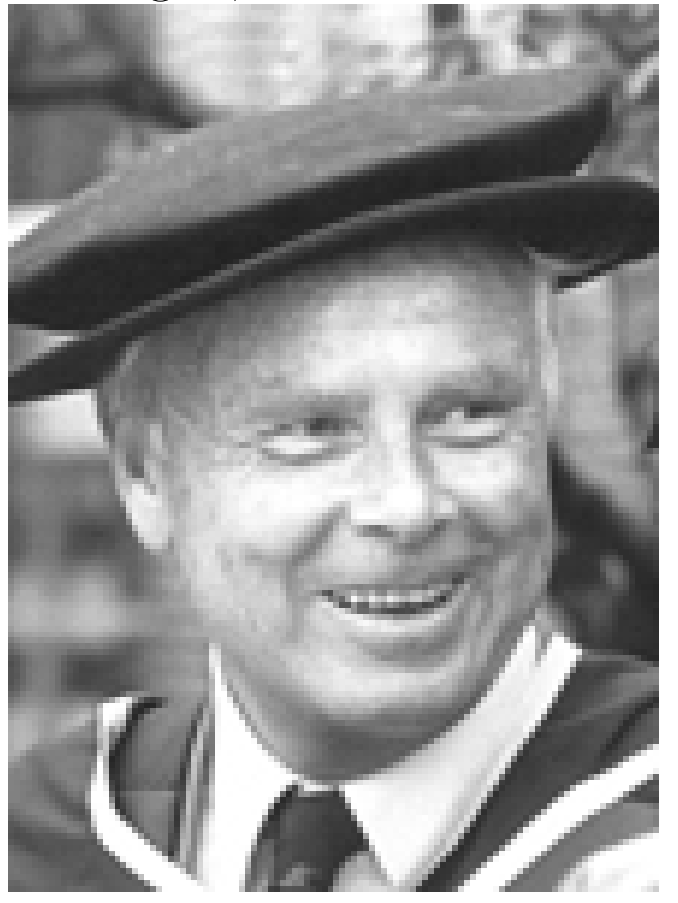


Produced an Army of Students and Coauthors, Many of Whom Became Important Contributors in Their Own Right
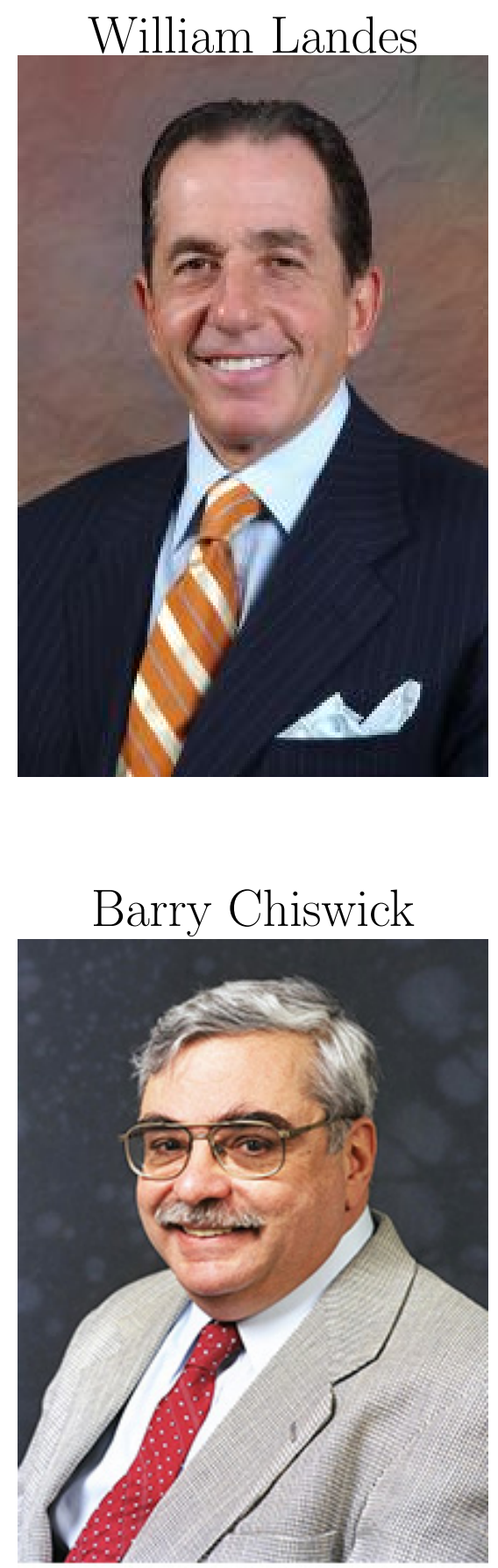


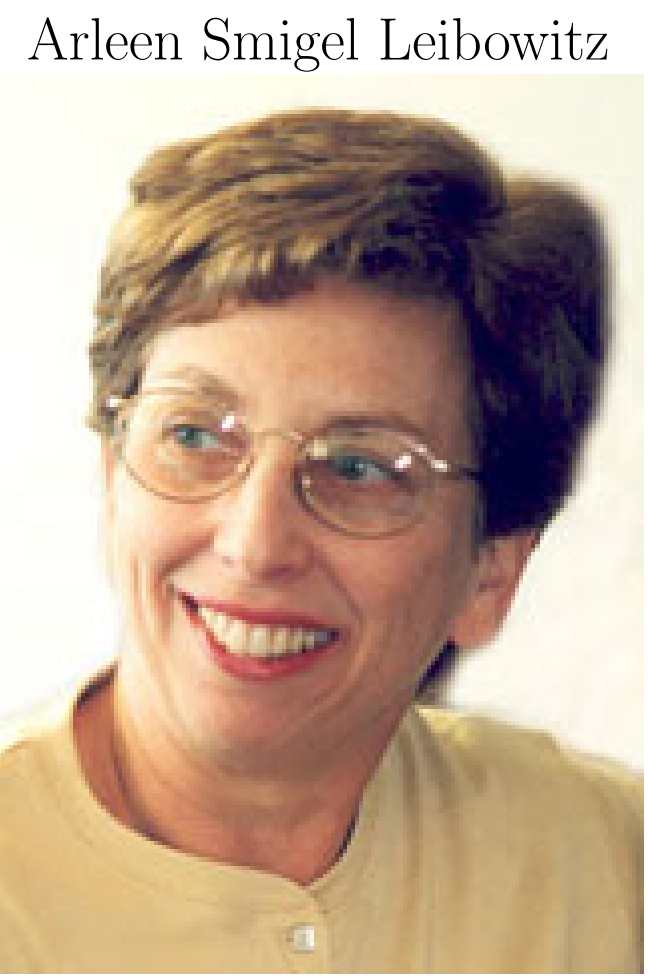

Mark Rosenzweig

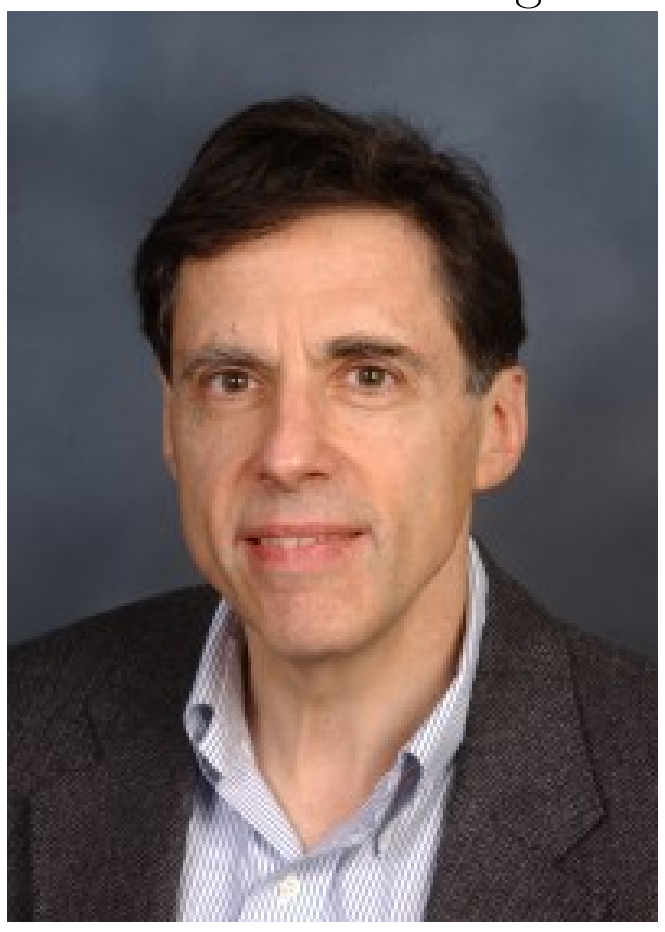




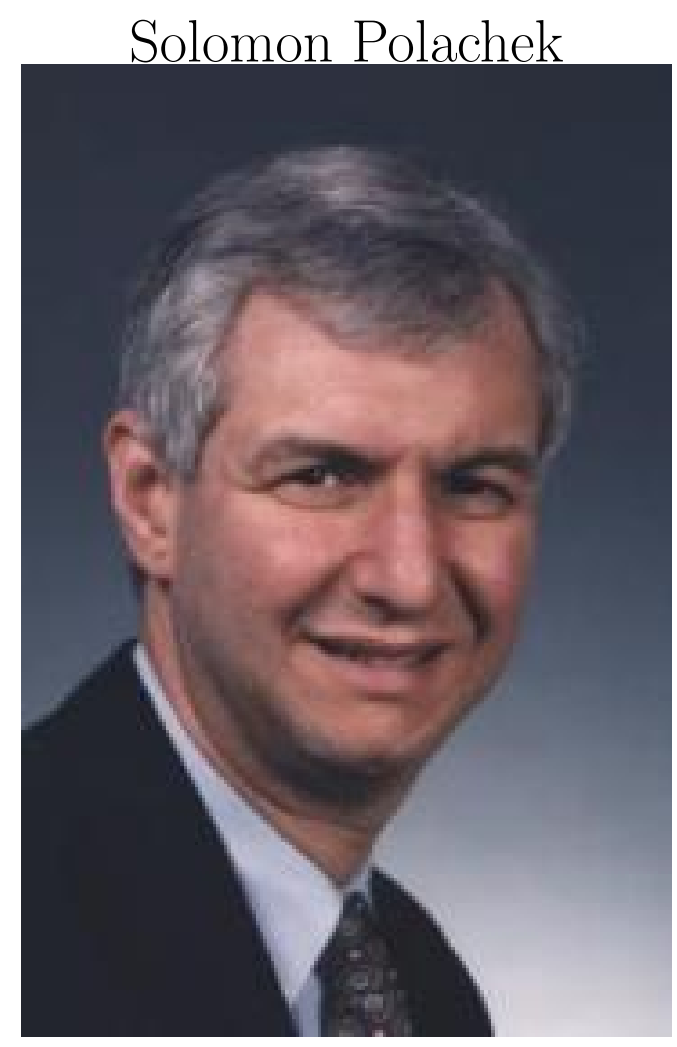

Andrea Beller

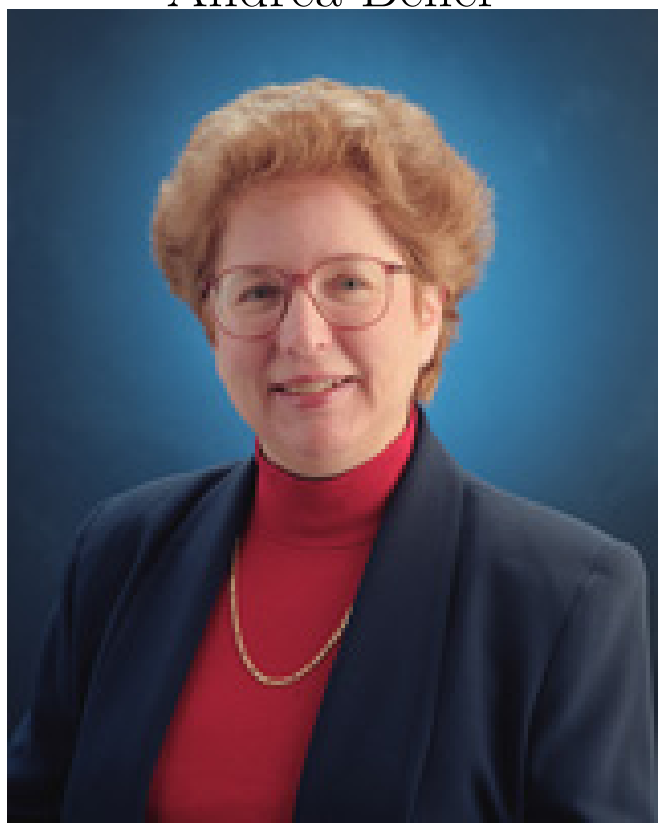



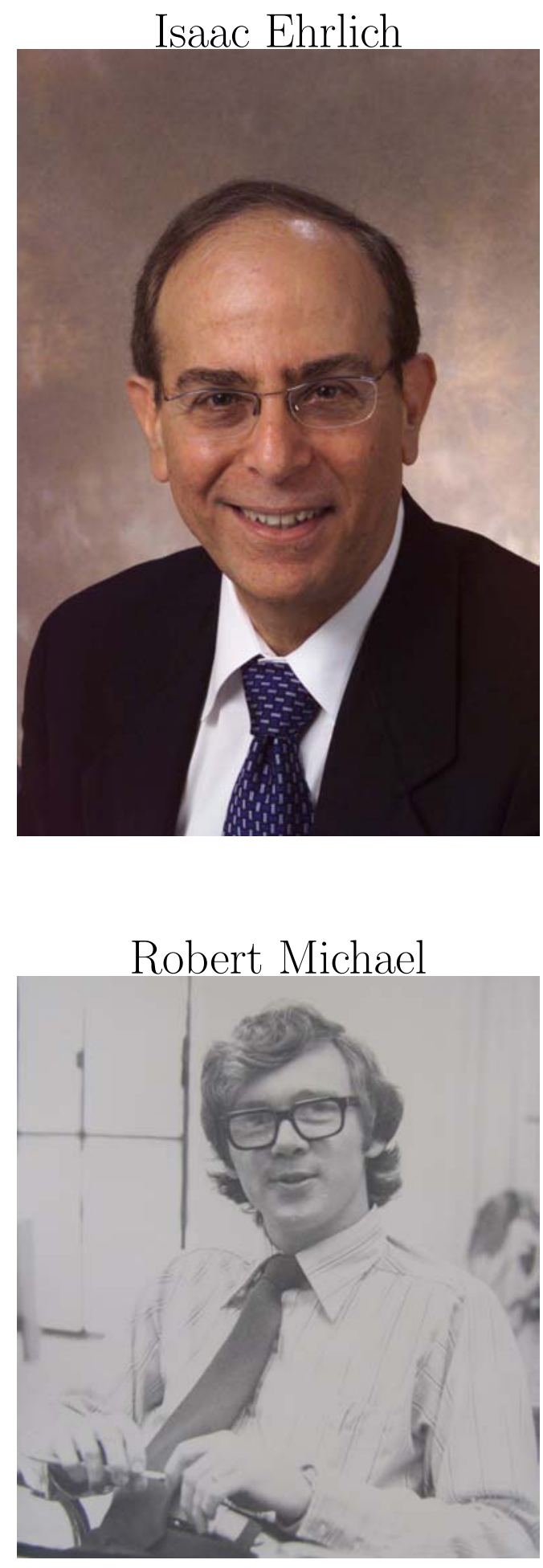

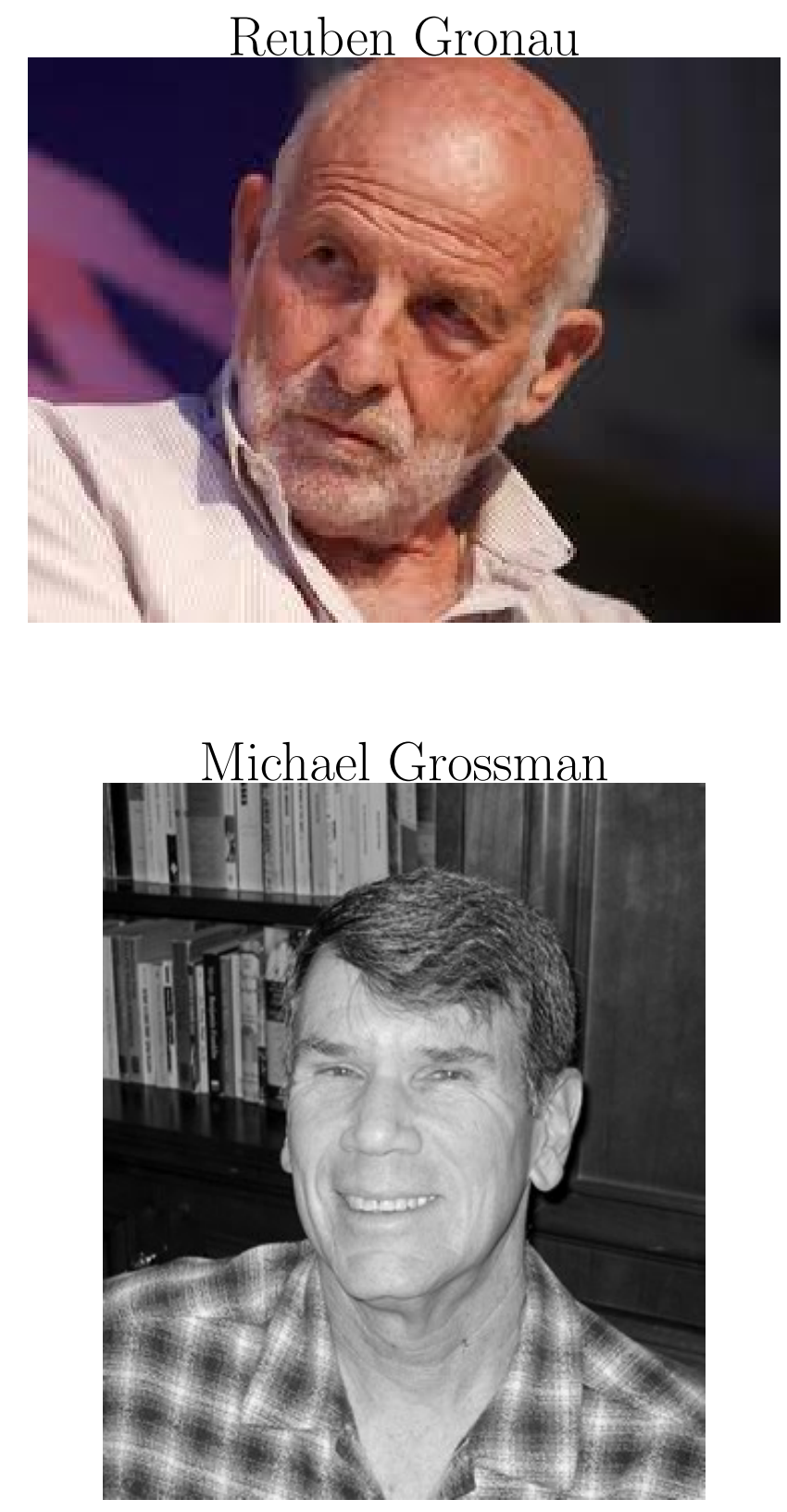


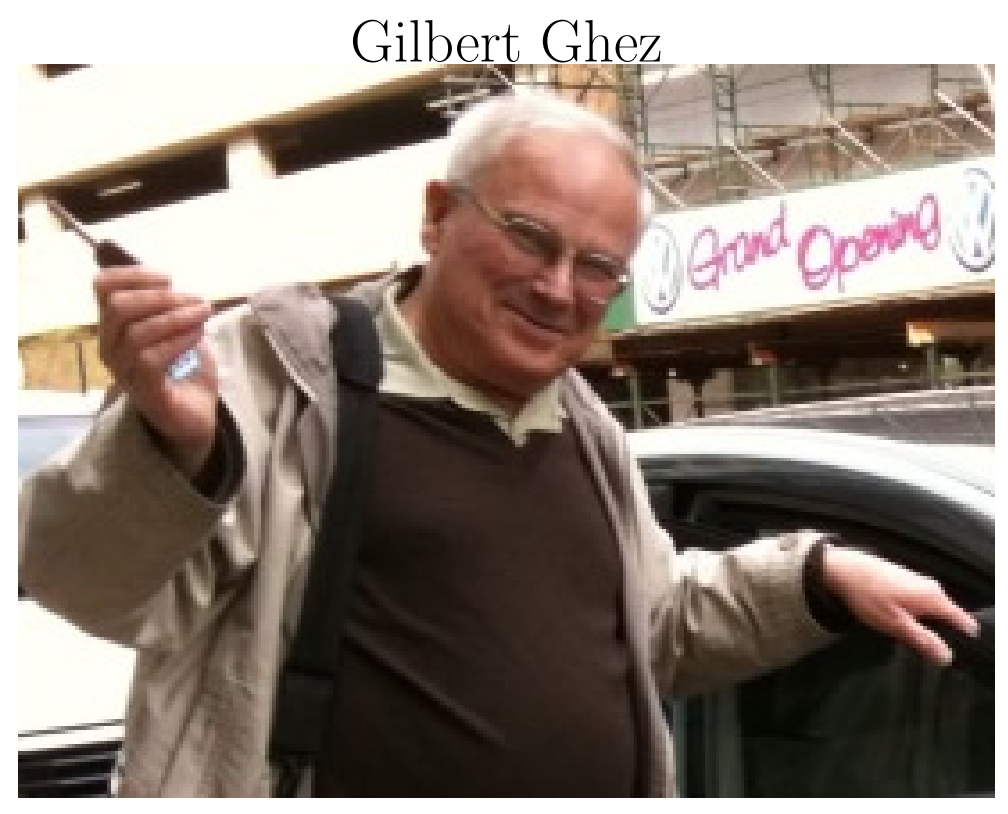

Haim Ofek

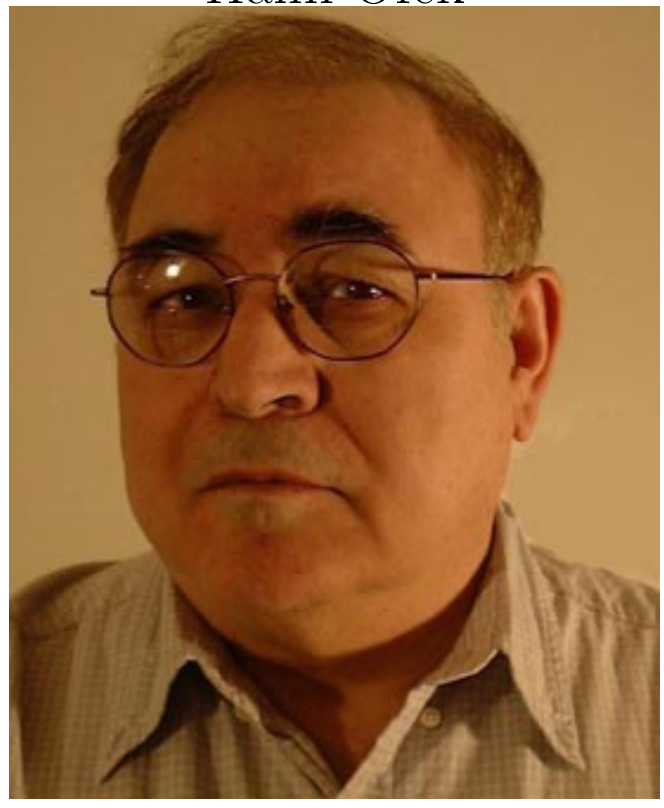




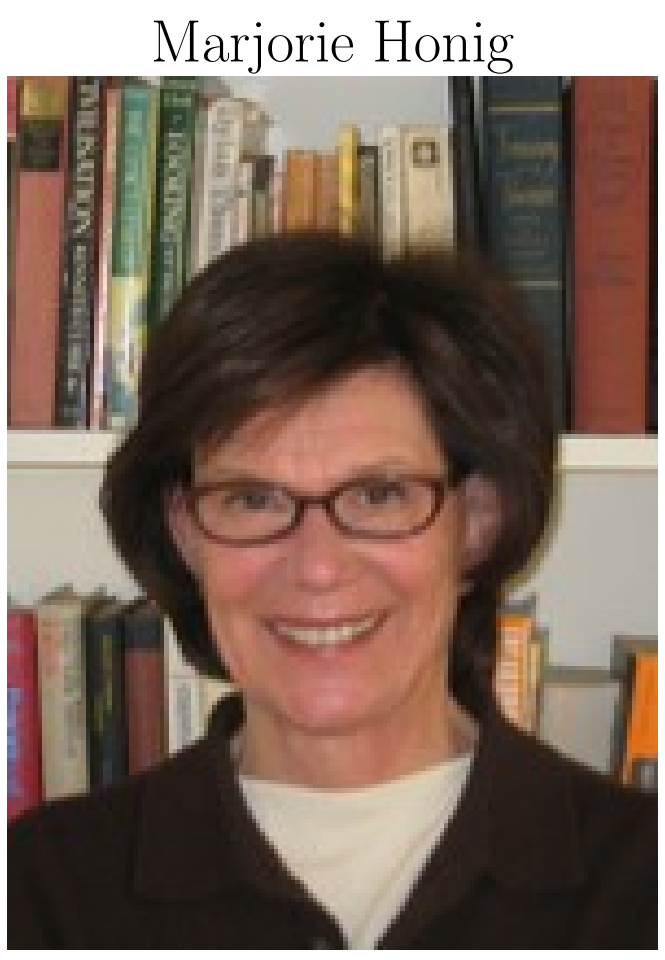

Lisa Landes

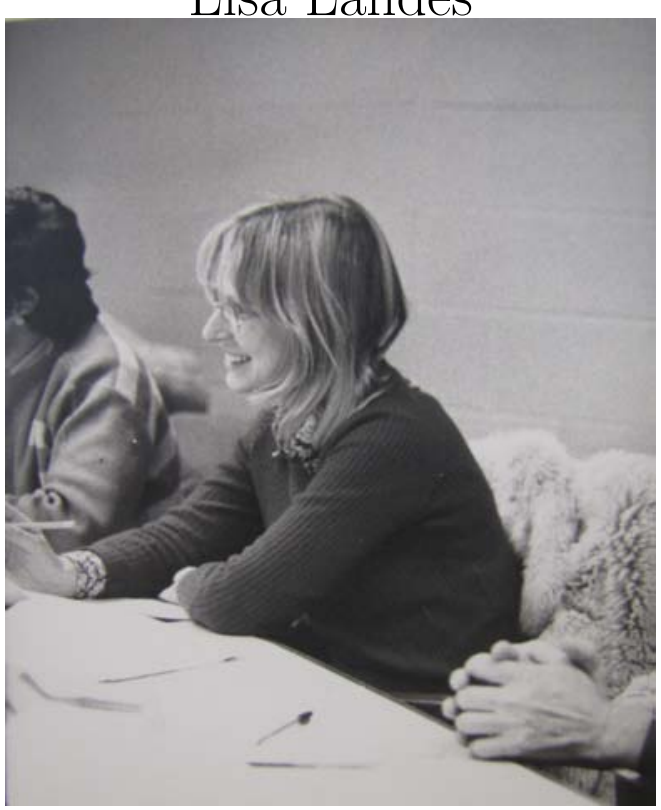




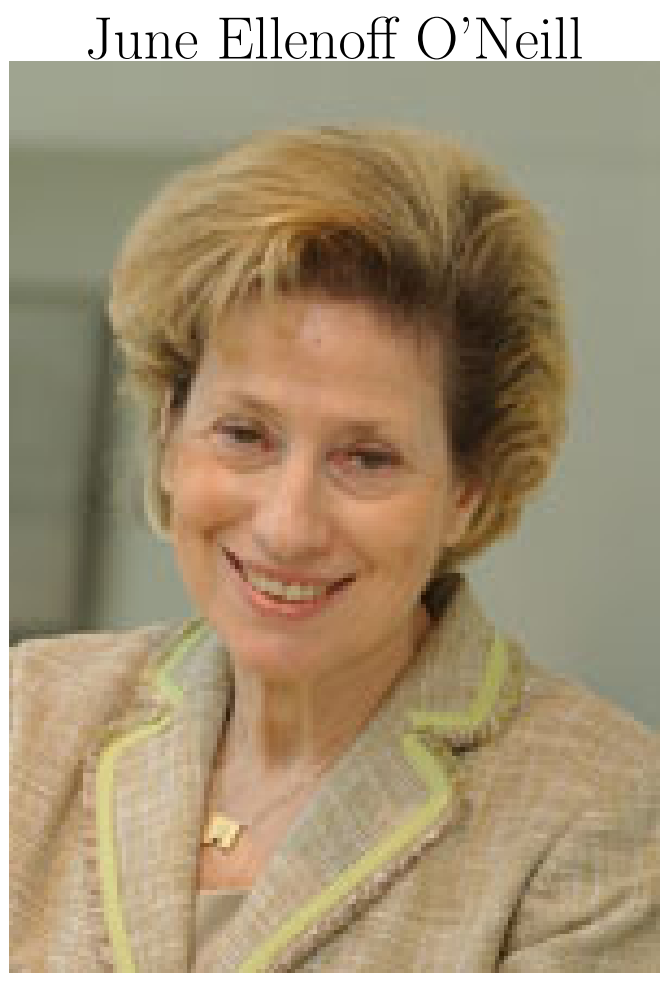

Dave M. O'Neill Picture Pending 


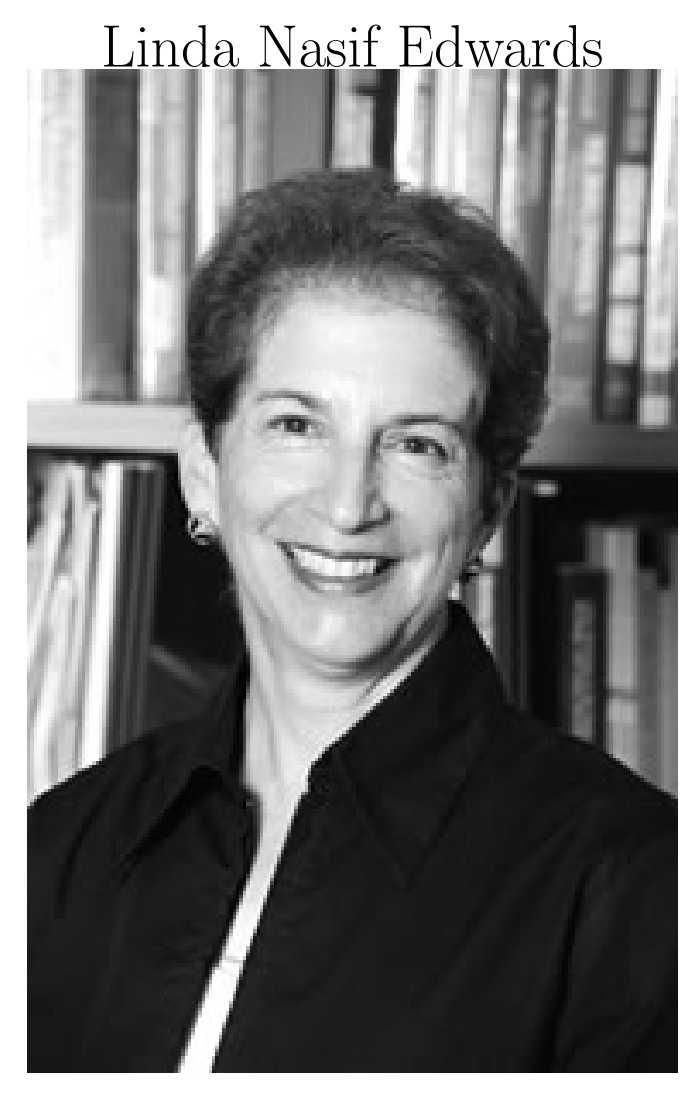

Arlene Holen Picture Pending 
In a period 1957-1969 had an incredible burst of creativity and produced an amazing array of students, many of whom became both disciples, collaborators, and prominent independent scholars in their own right.

He formed a link with NBER. Solomon Fabricant supported a project on measuring the rate of return to education, which led to his fundamental work on Human Capital (1964).

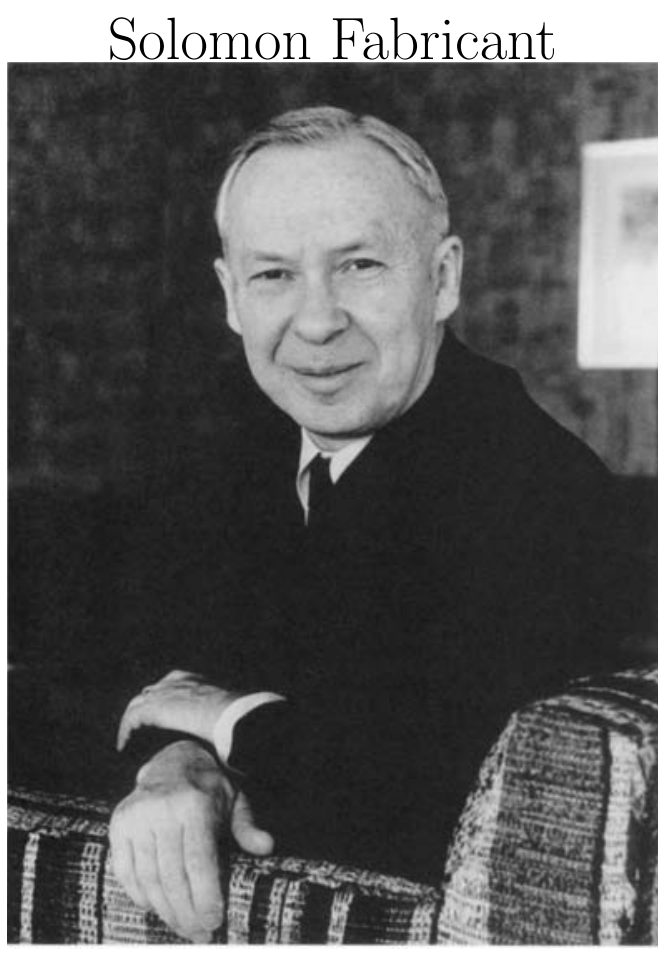



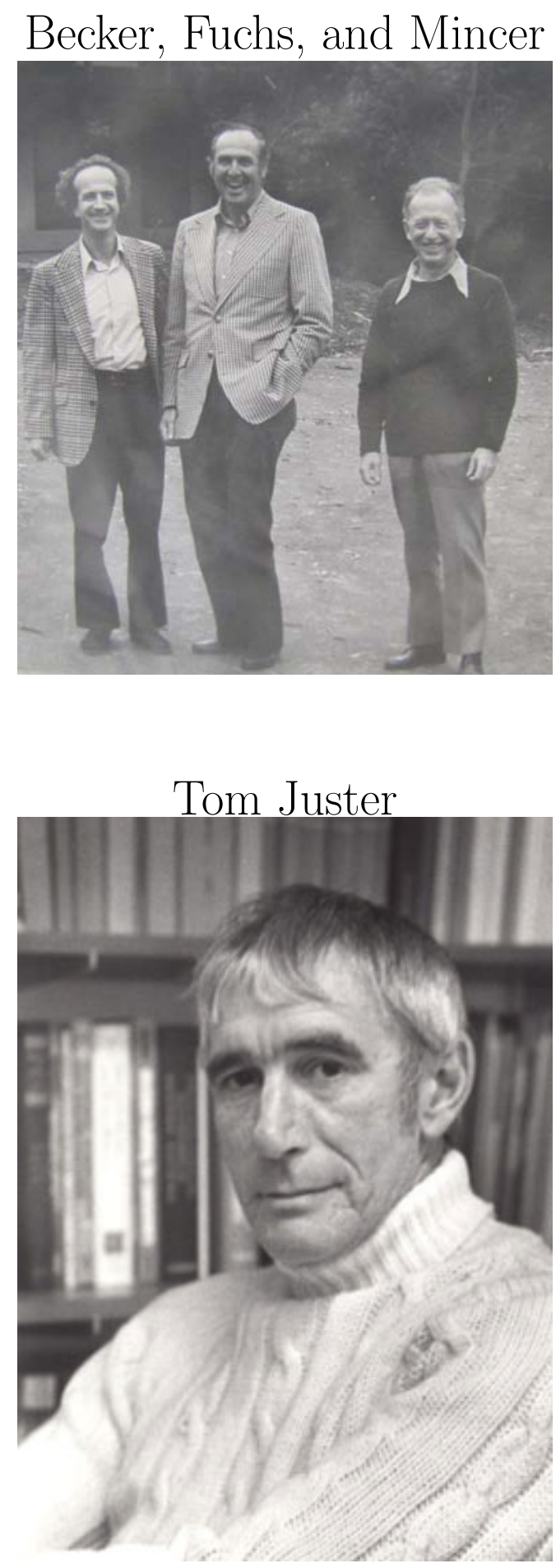
Becker Energized NBER and Reinvigorated It — Some Would Say He "Beckerized" it.

Gave it a focus on microdata and analysis of social problems. 
(Power of Synergies and Peer Groups)

NBER NY 1960s - early 1970s

Motivated whole new fields at NBER:

1. Health

2. Law and Economics

3. Labor Studies

4. Child Studies and later programs cloned out of these

One measure of his success was the enthusiasm that students showed for him. They saw that he was smart, that he was doing something really new, and that this was worth doing and being a part of. 
He Attracted Distinguished Research Associates and Visitors at

\section{NBER}

Finis Welch

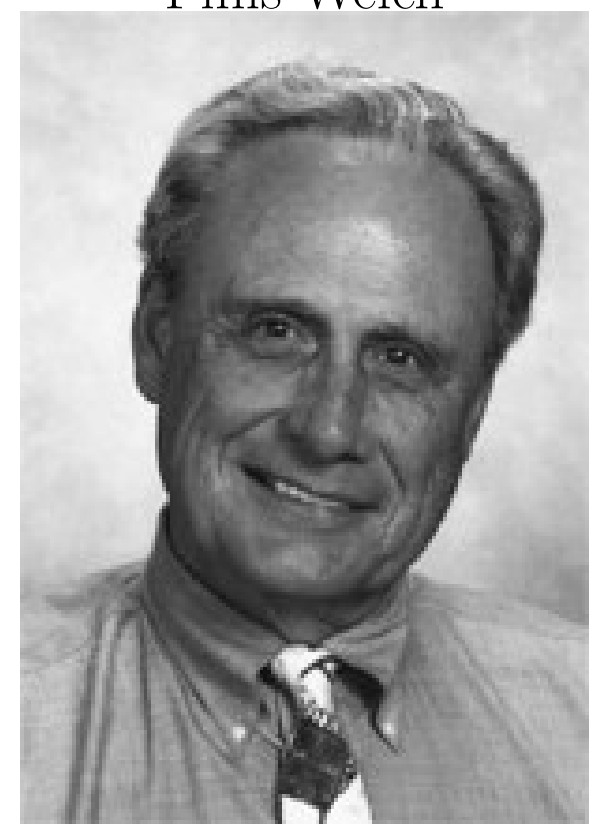

Bob Willis

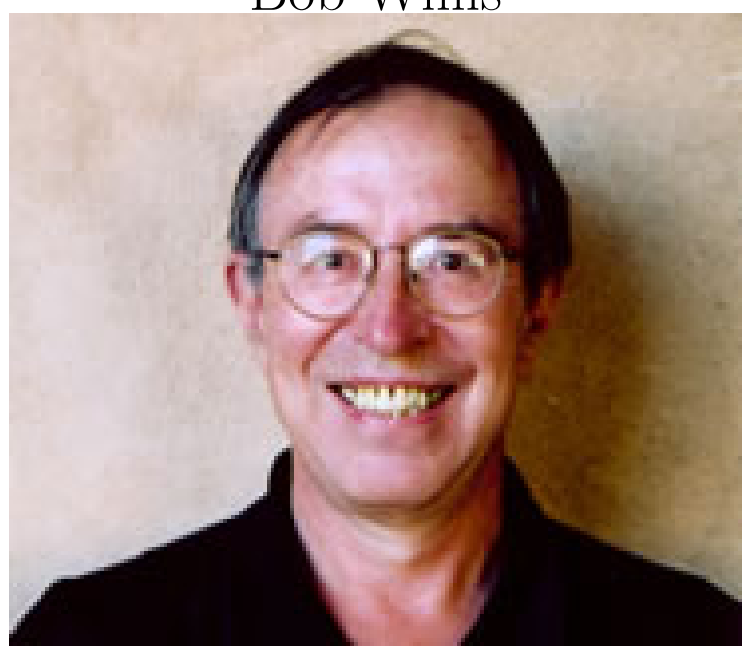



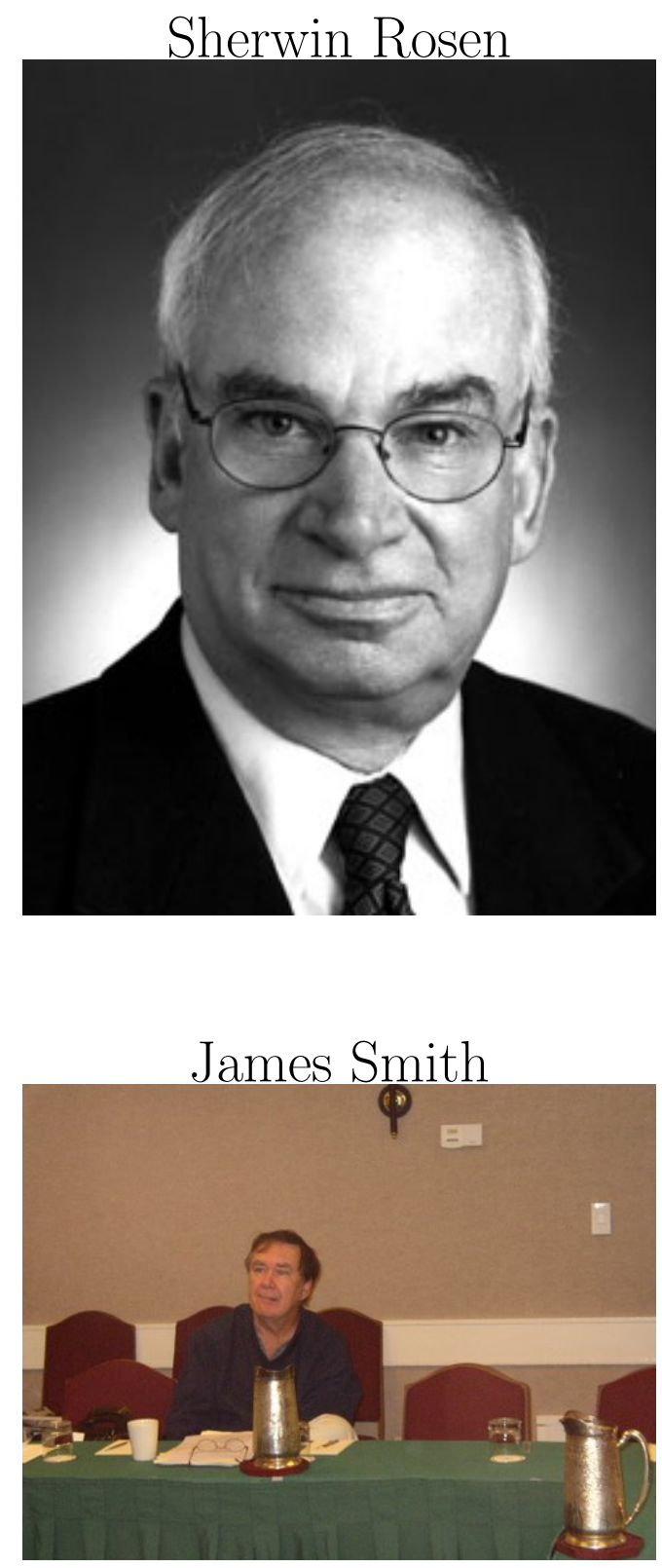

Each emerged as independent major scholars in their own right. 
Moved Back to Chicago (Visitor in 1969 and Permanent Faculty Since 1970: 47 Years at Chicago)

- Said he was "getting stale at Columbia."

- Columbia ravaged and mortally wounded by 1968 riots and response of the administration to them

- Chicago's response far more firm. (Edward Levi)

- Becker was waiting in the wings when he arrived but was not yet on center stage.

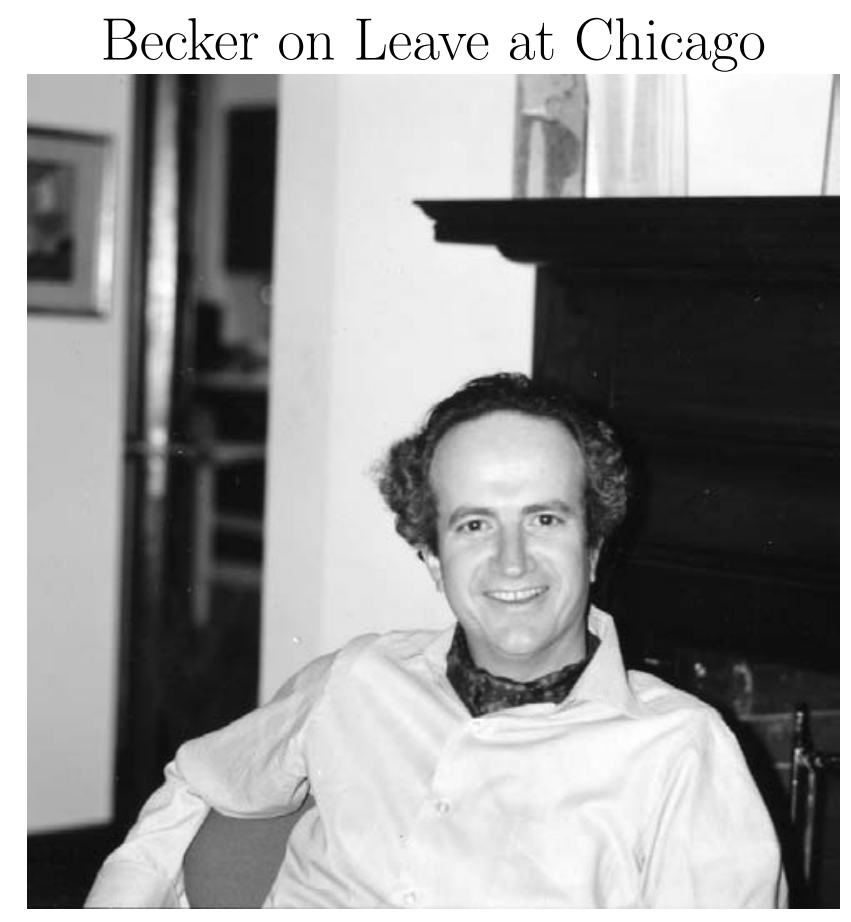




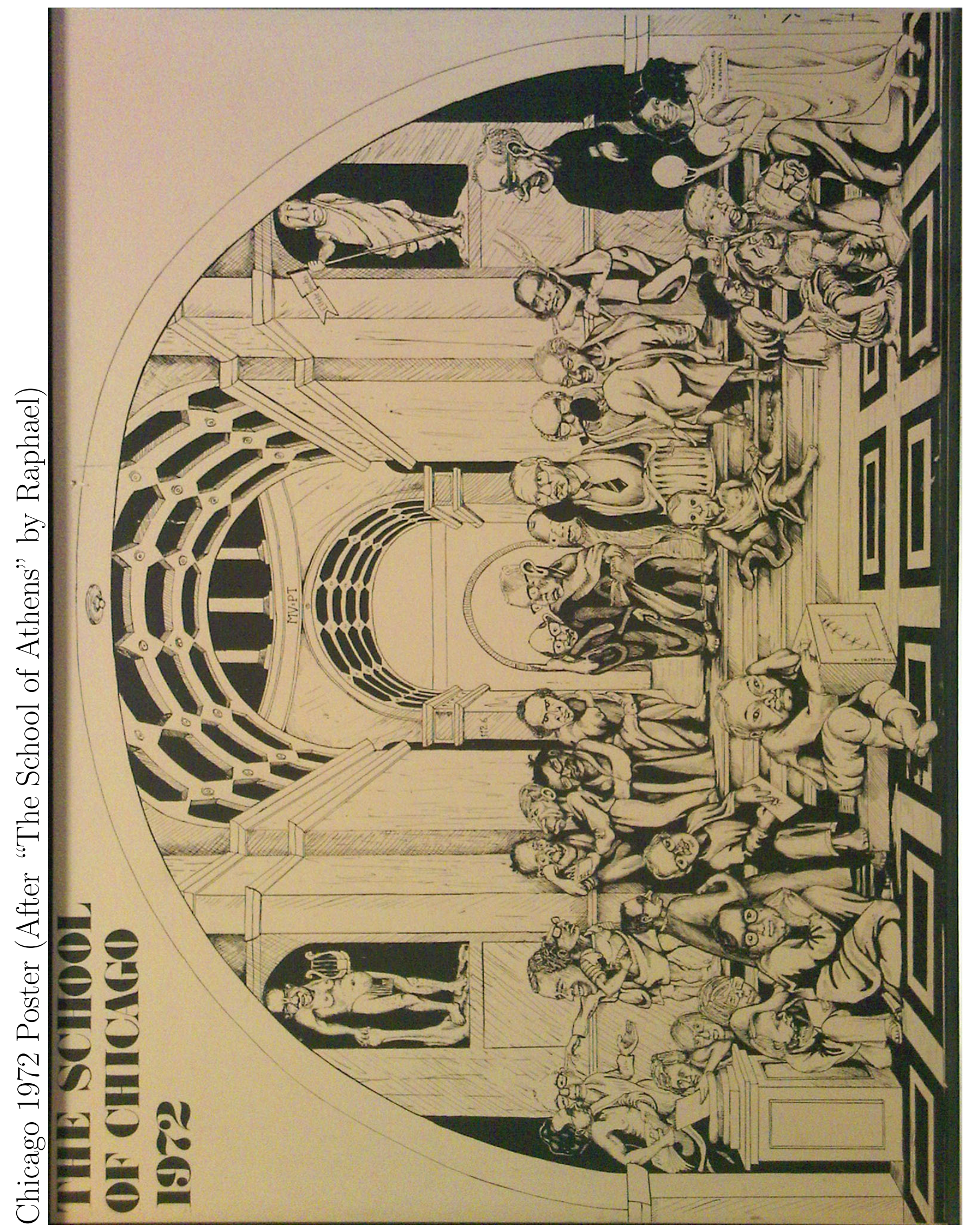


"The Long and Short of the Chicago School: Early 1970s

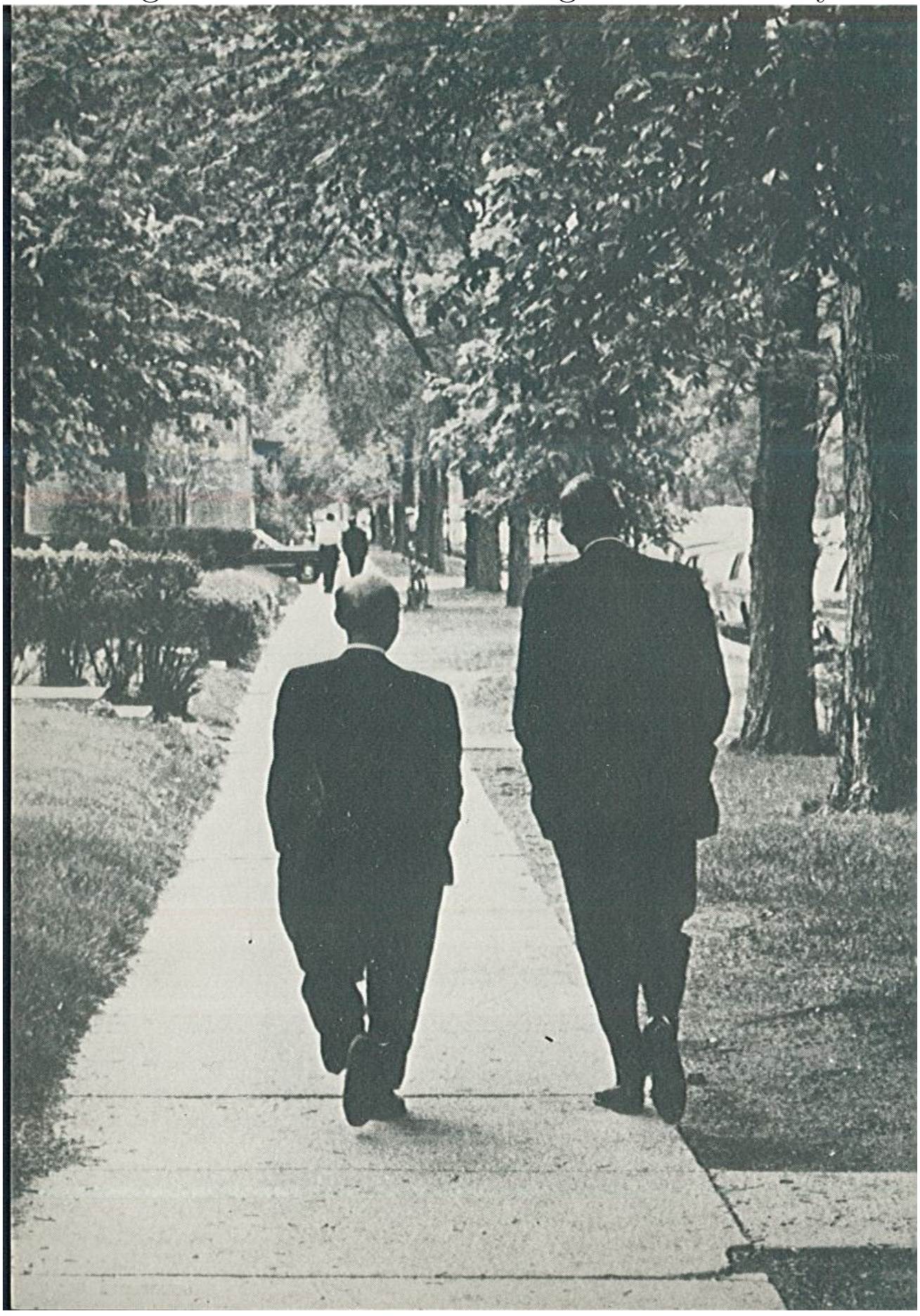




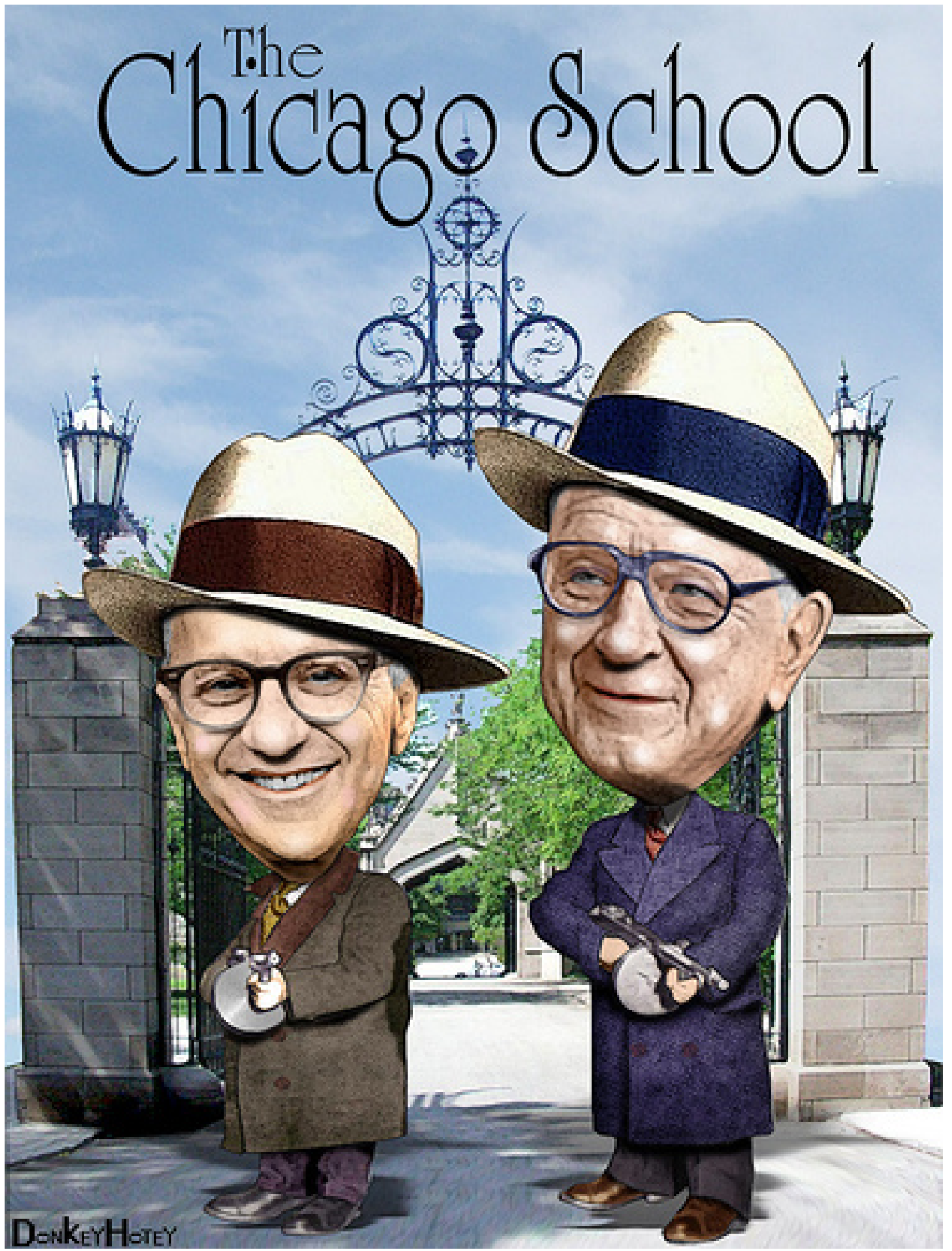



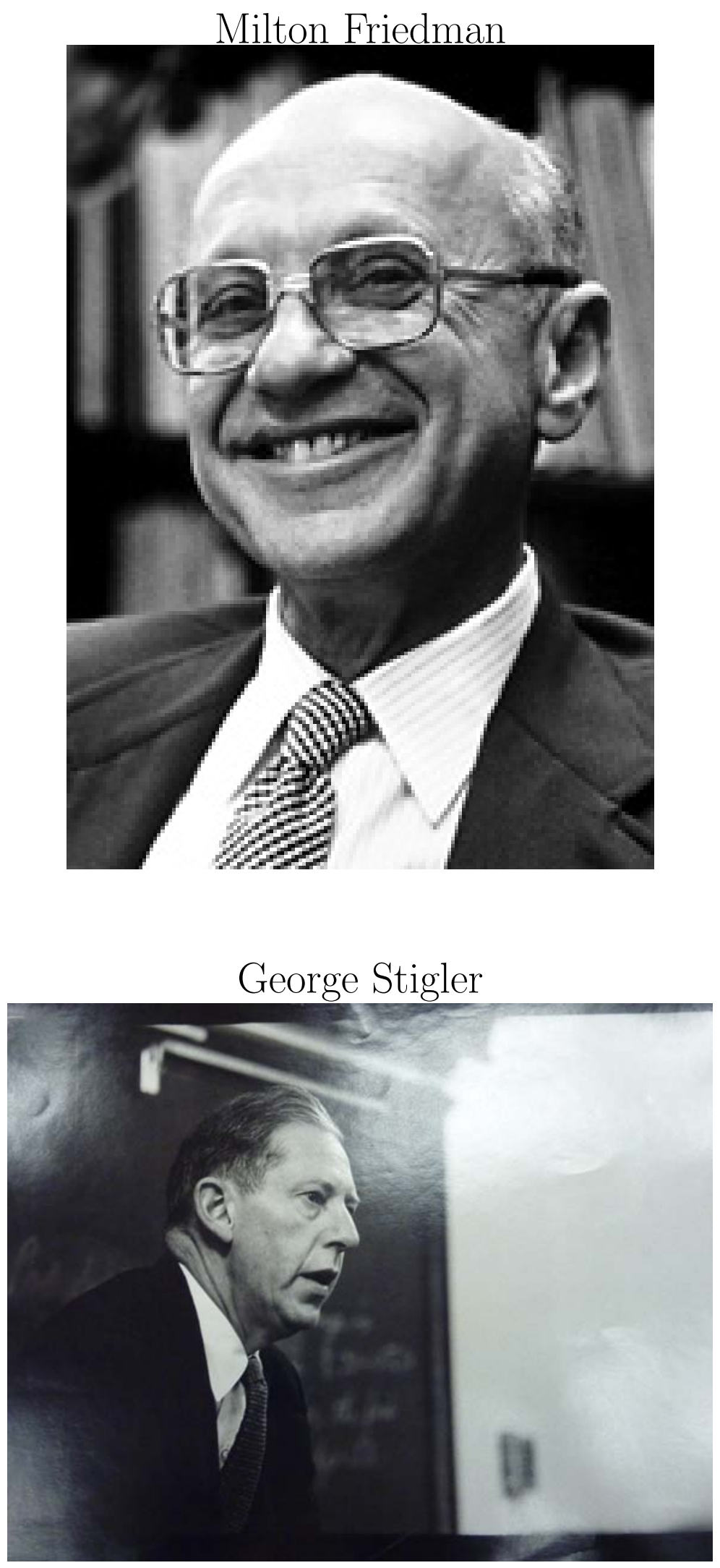
George Shultz

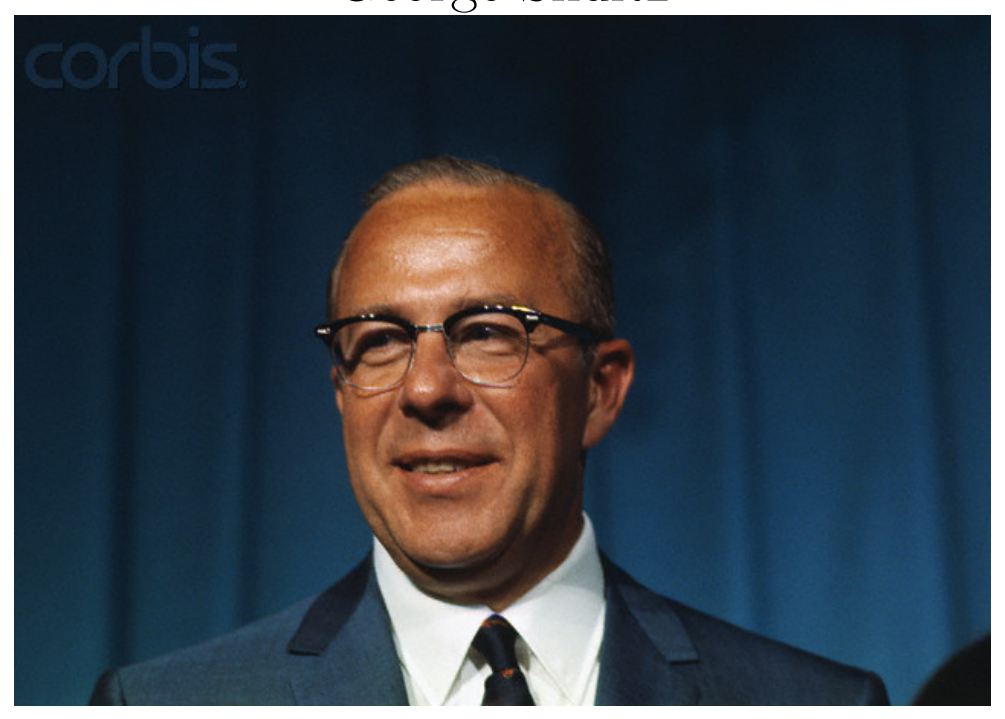




\section{Individual Photos}

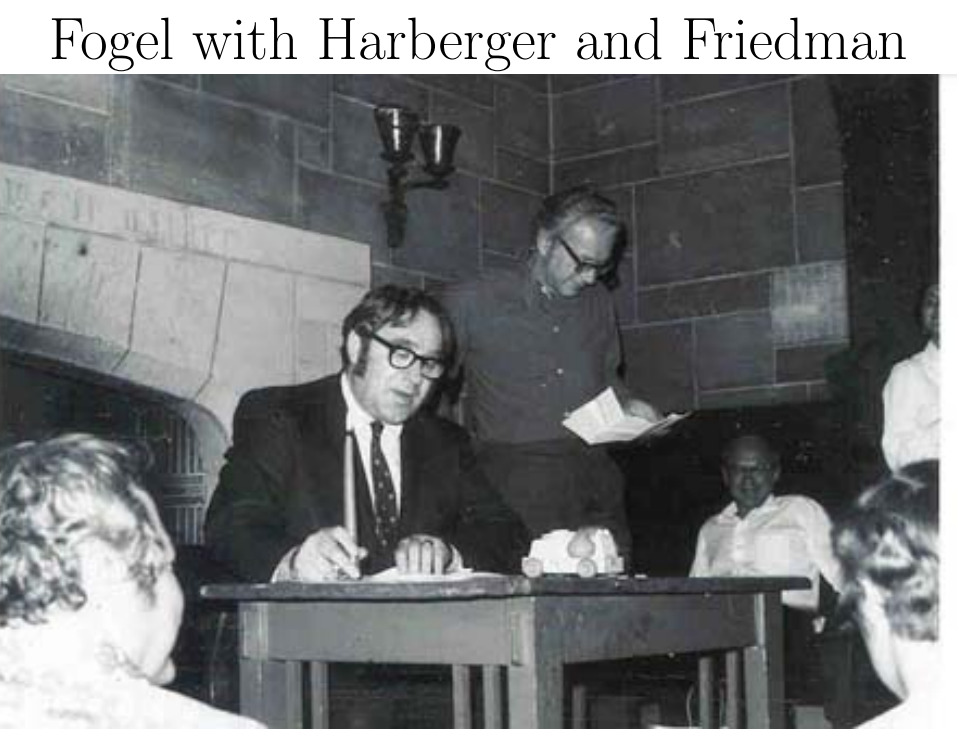

Harberger as Triangle Man

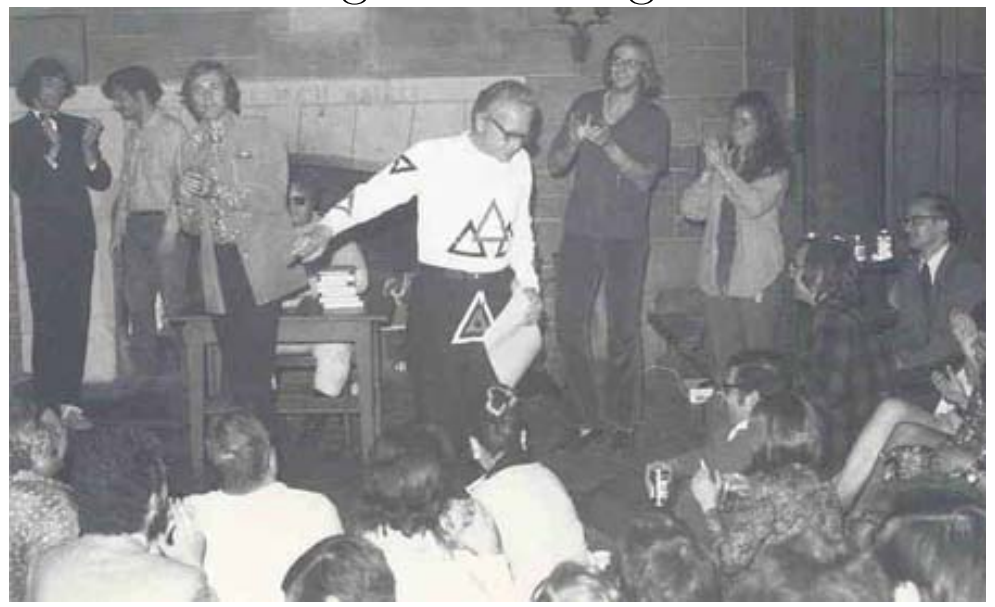



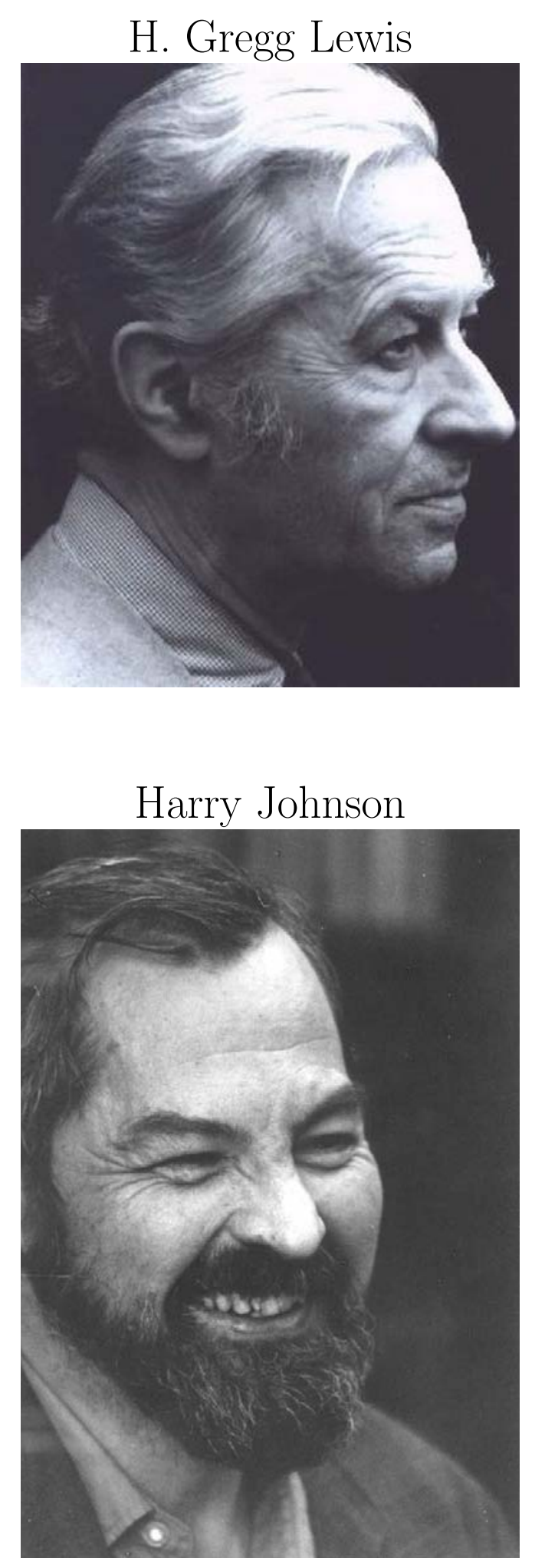

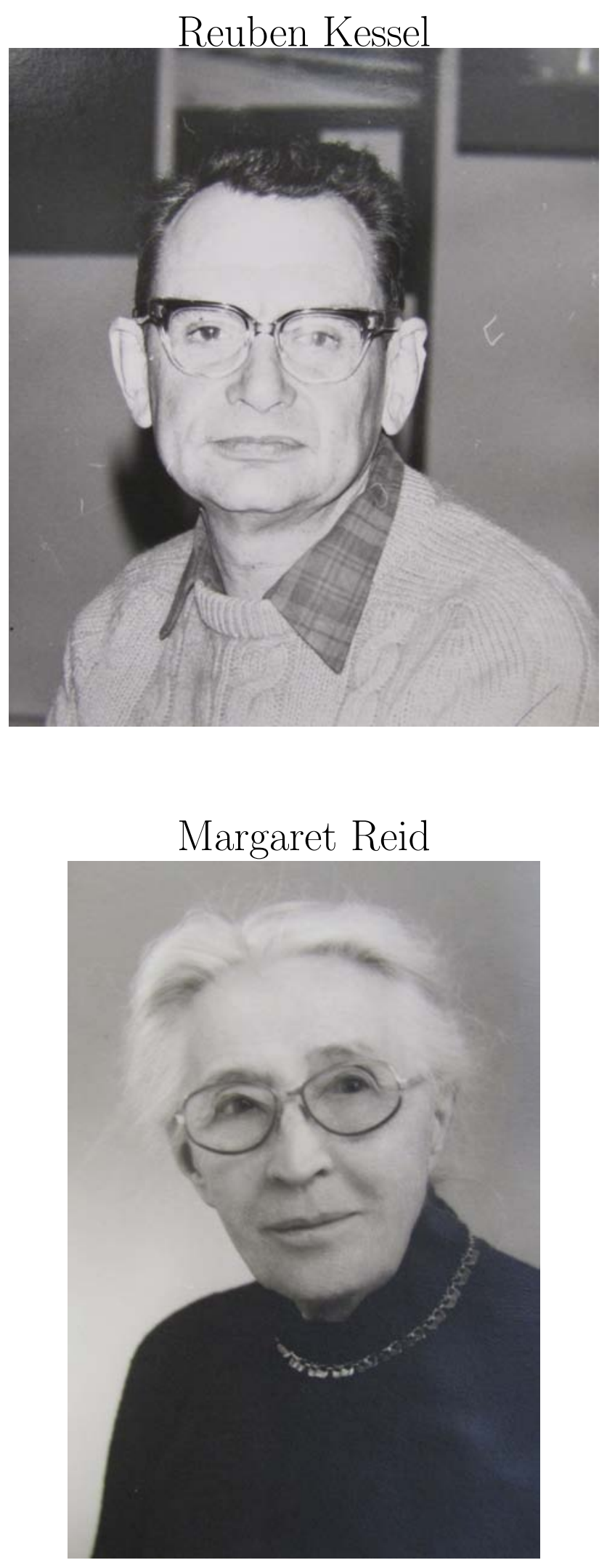

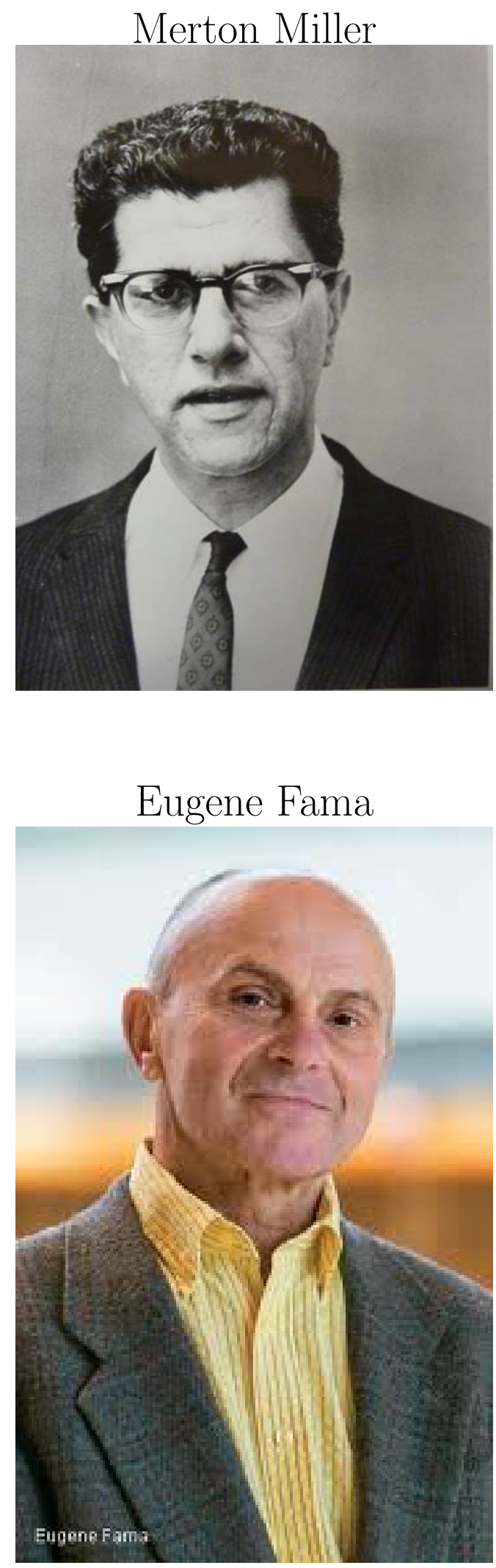

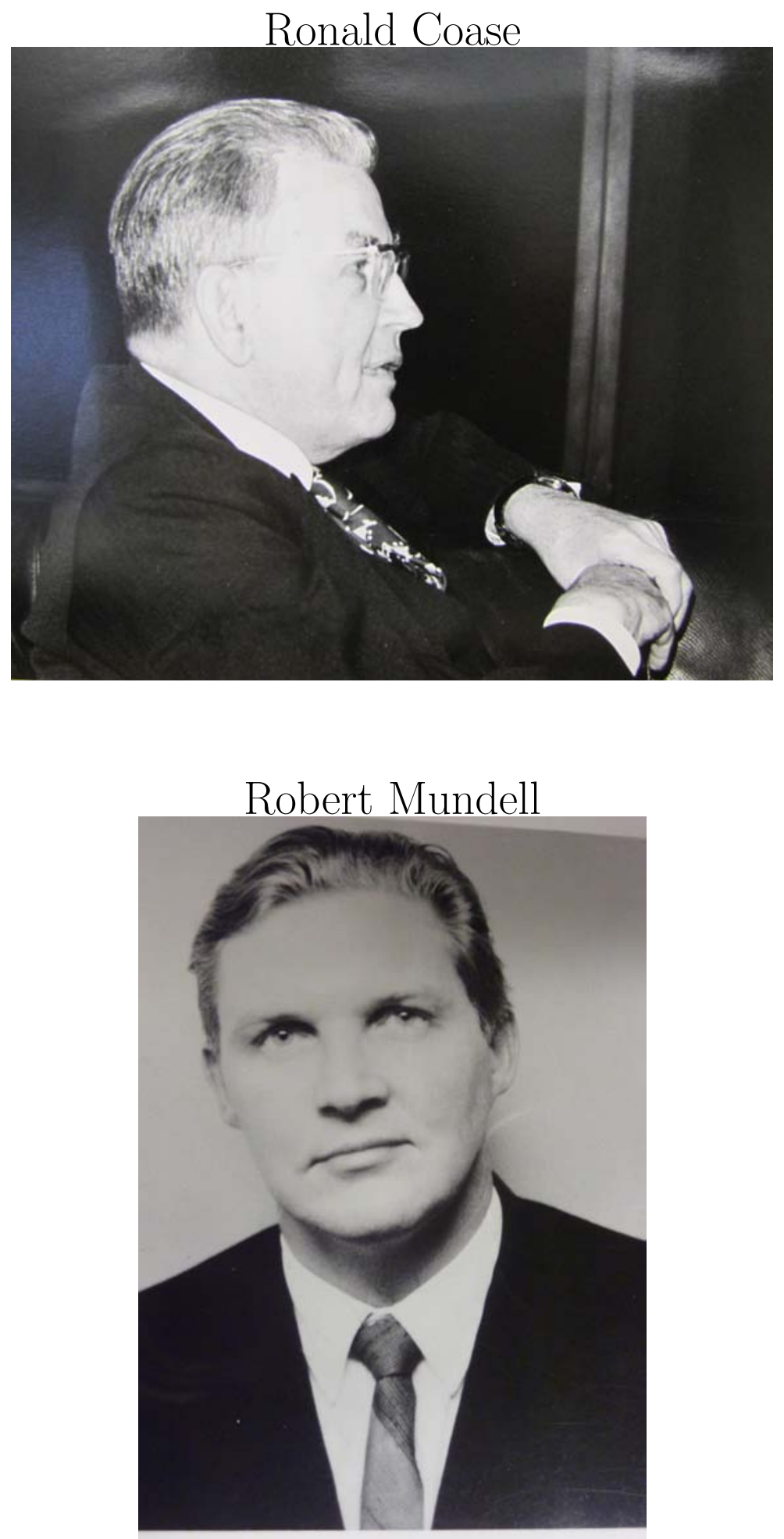


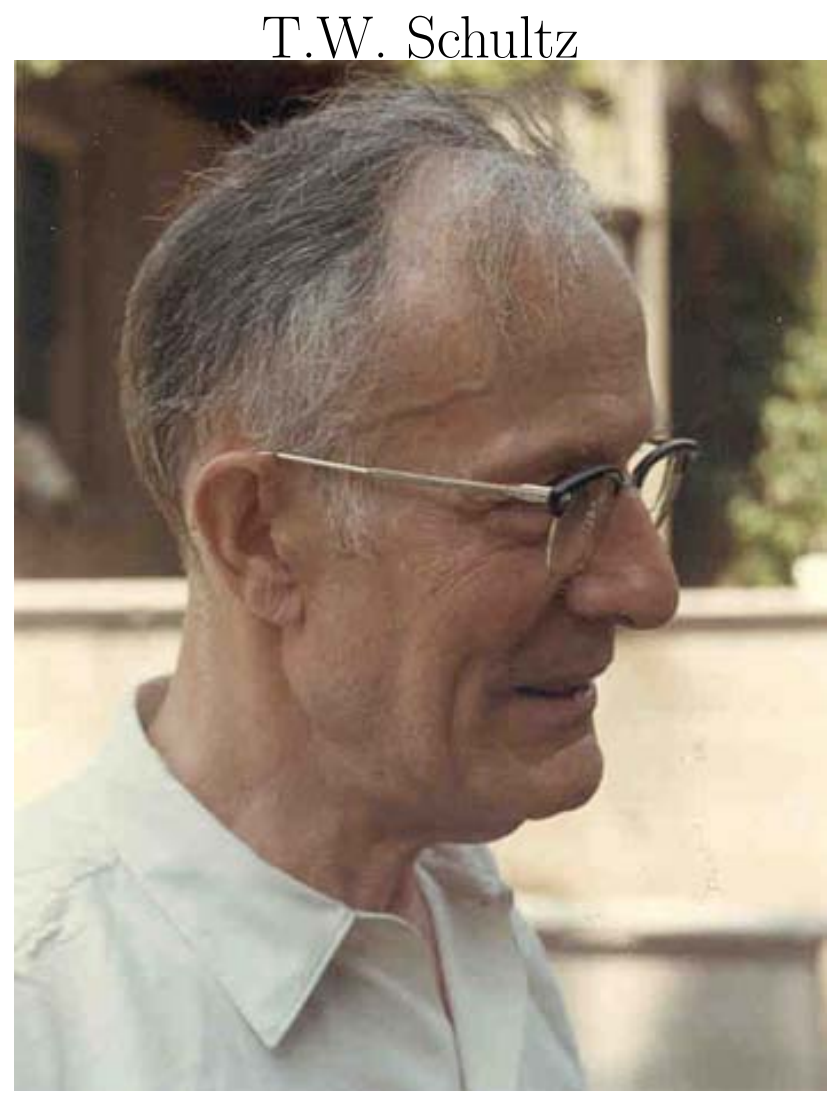

Robert Fogel

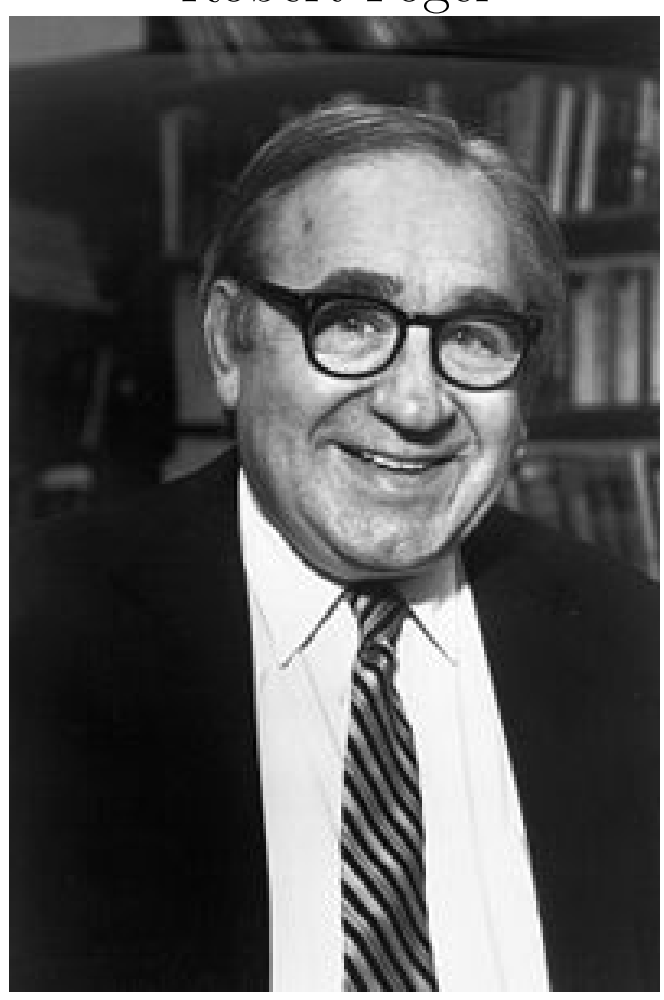



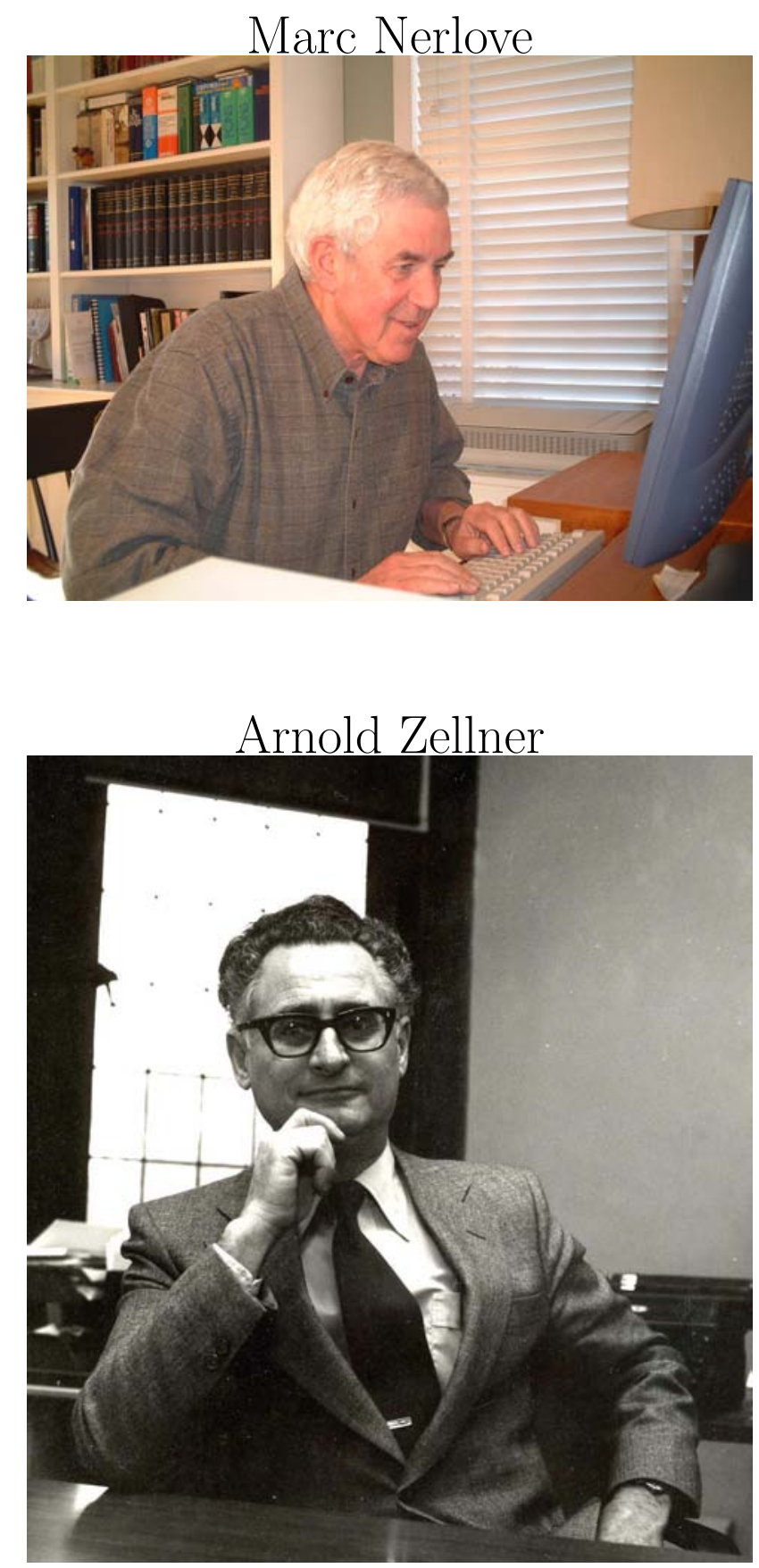
Henri Theil
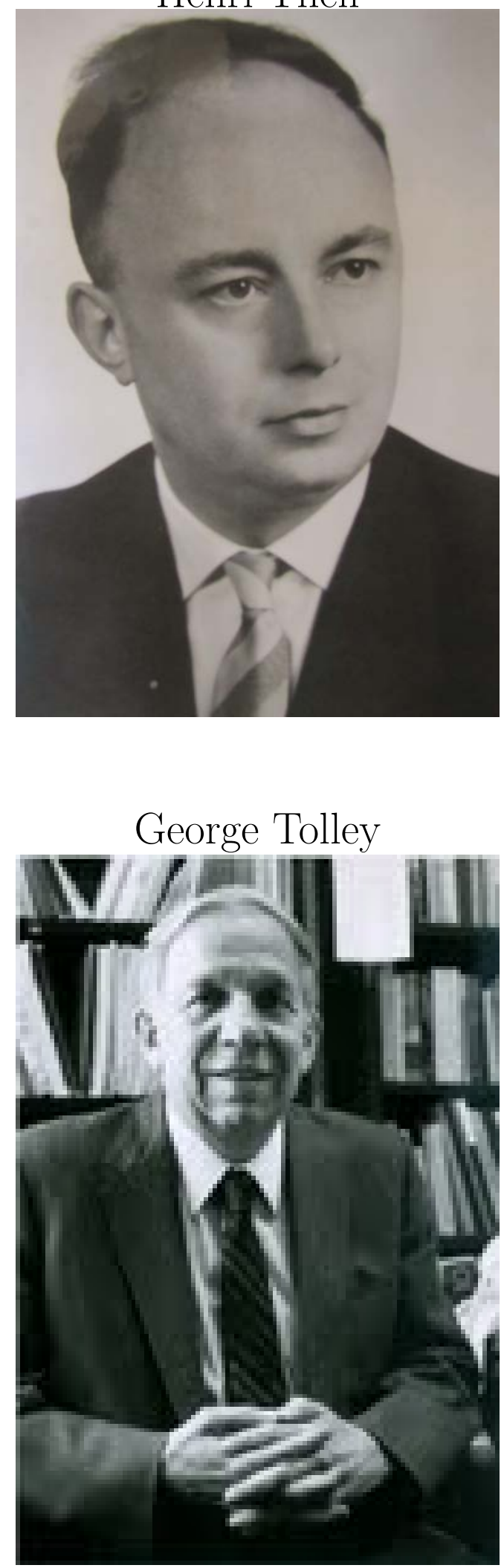

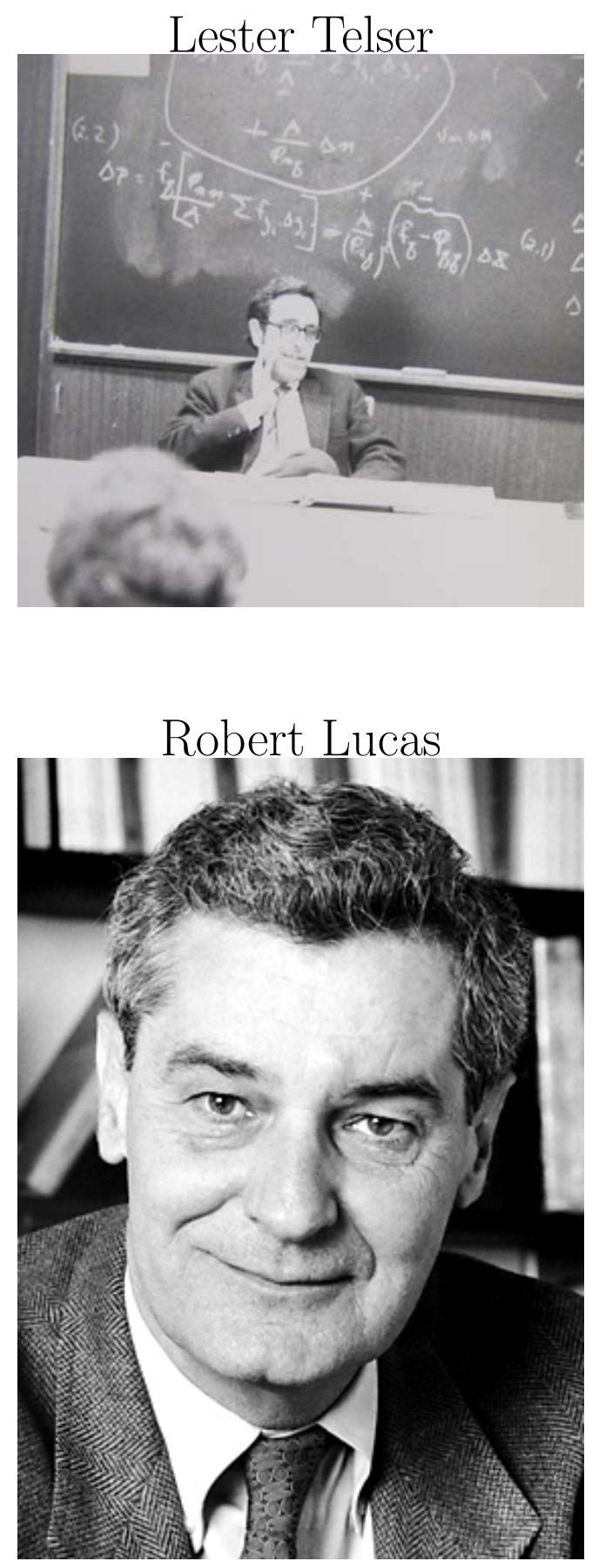
More Junior Faculty

Fischer Black
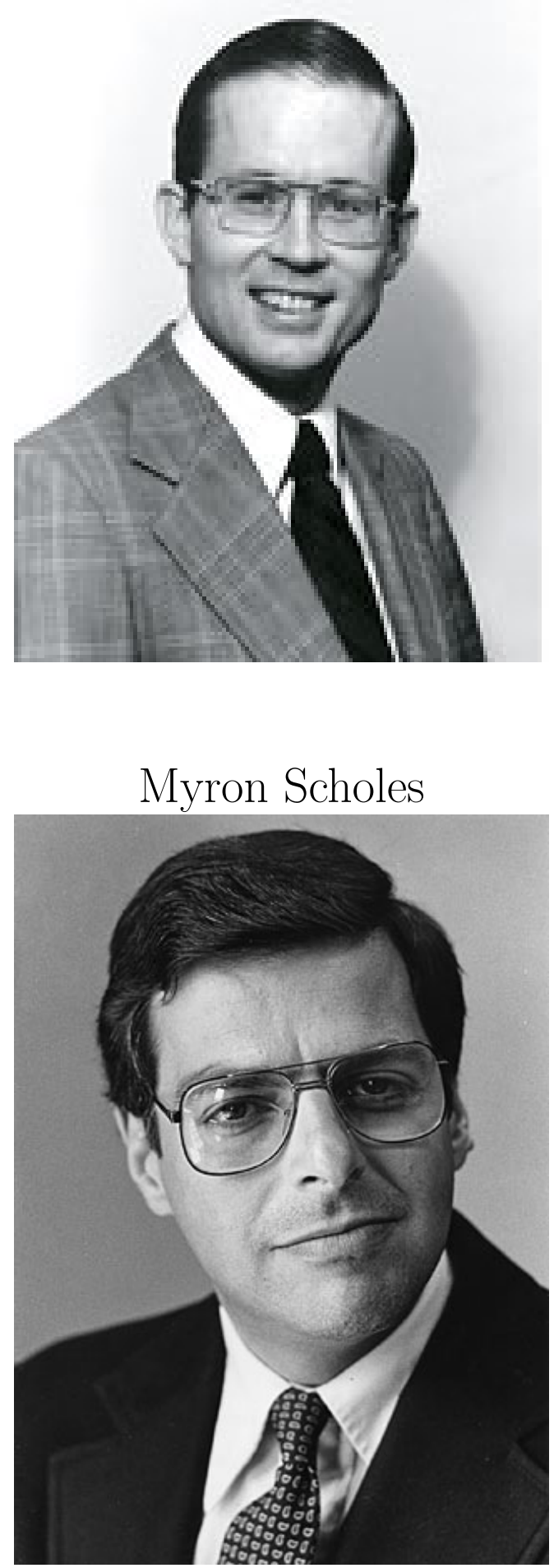


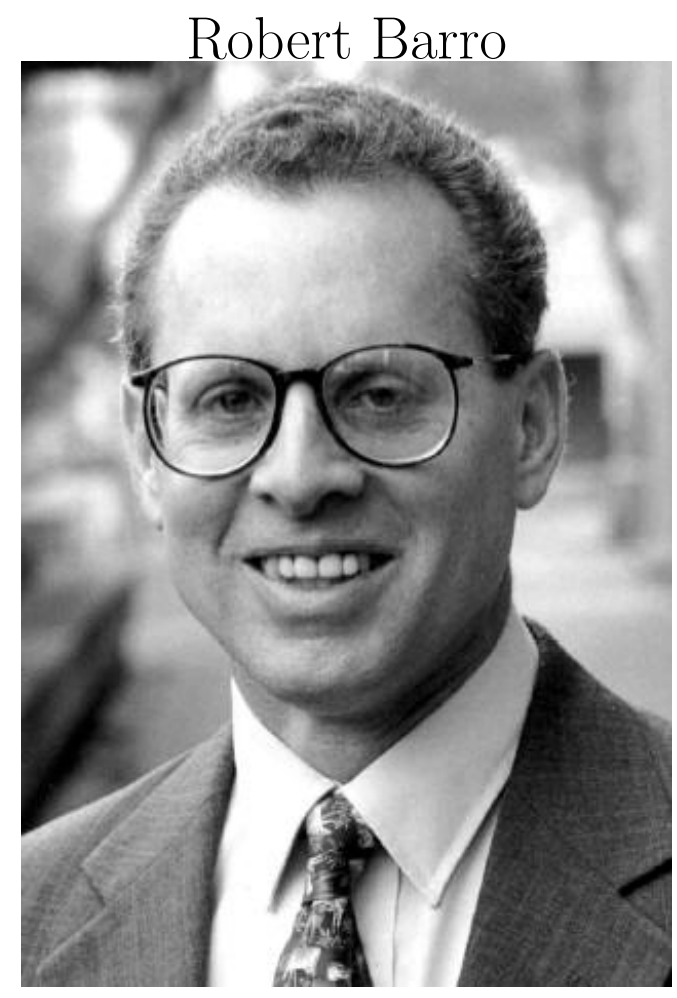

Donald McCloskey

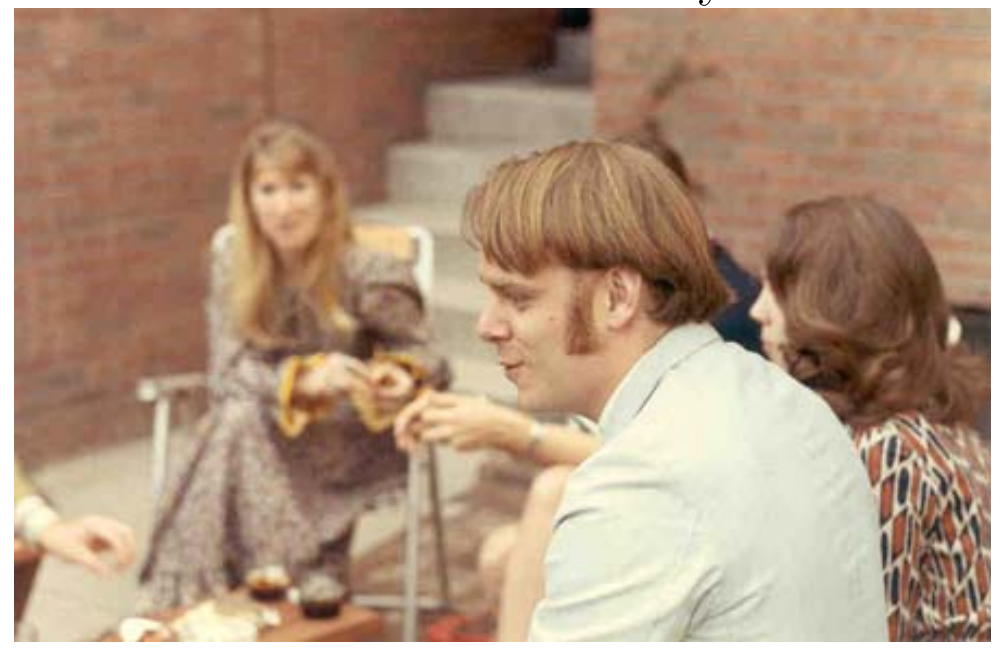




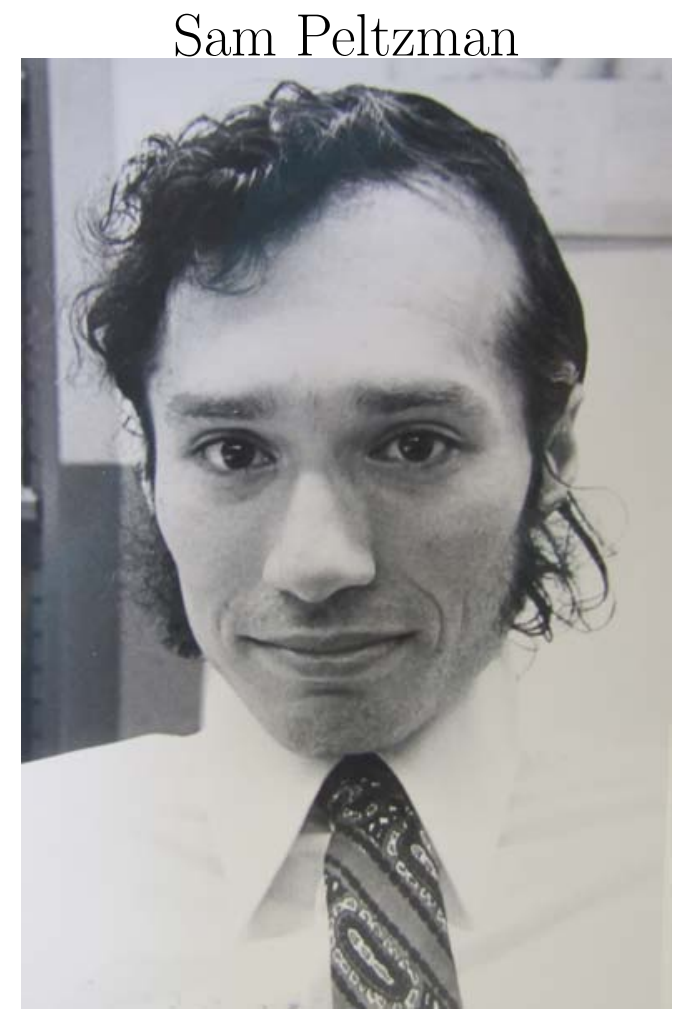

Robert Gordon

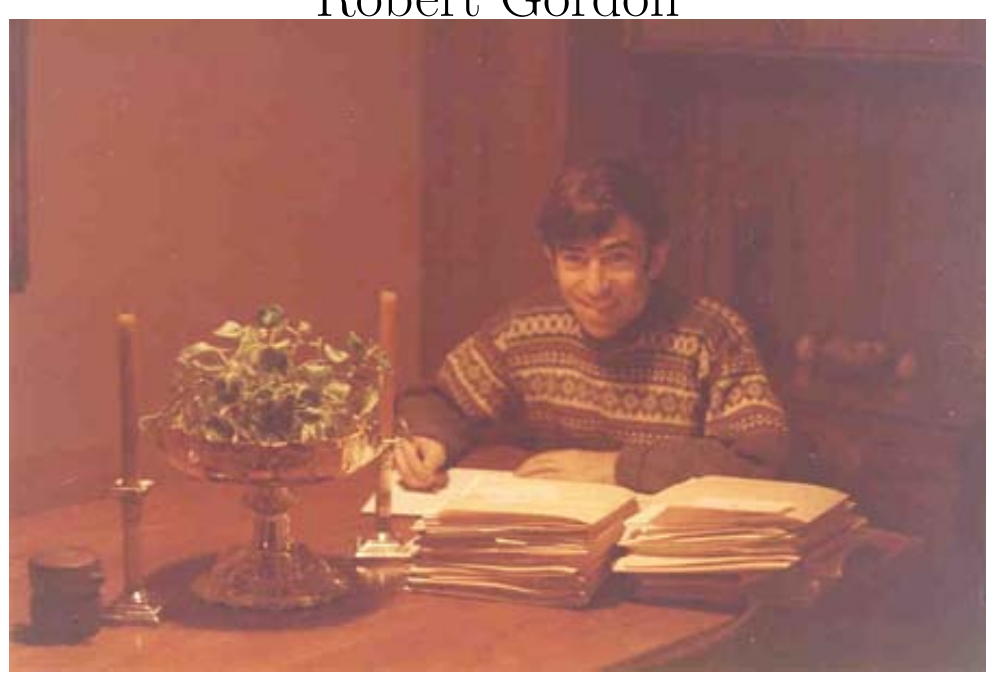


Stanley Fisher

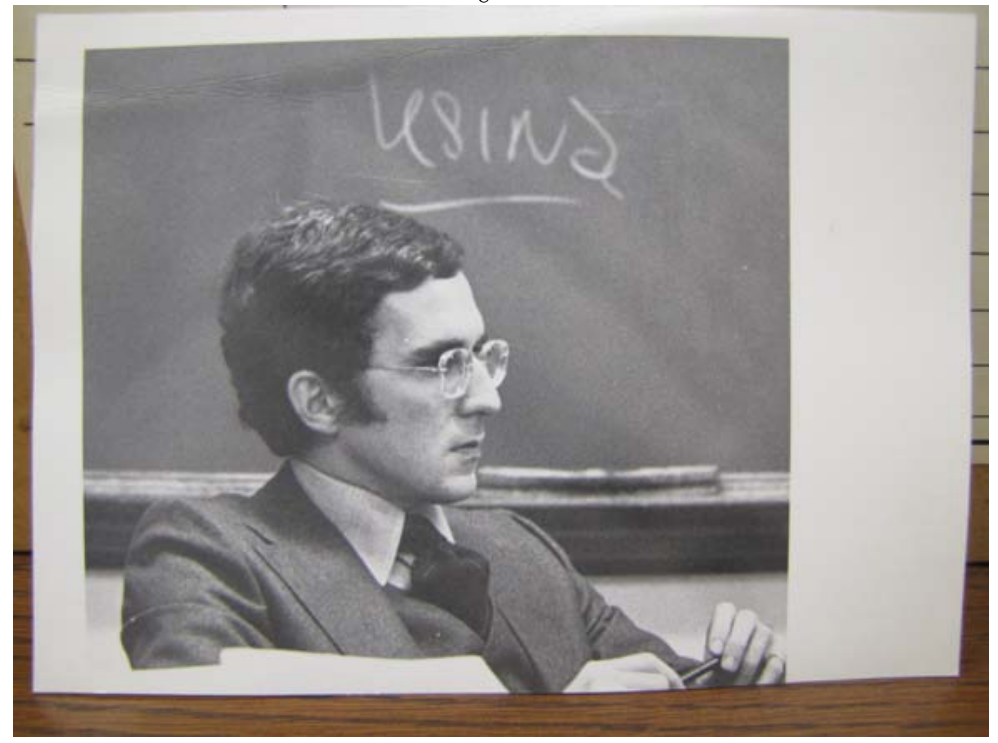

Richard Posner

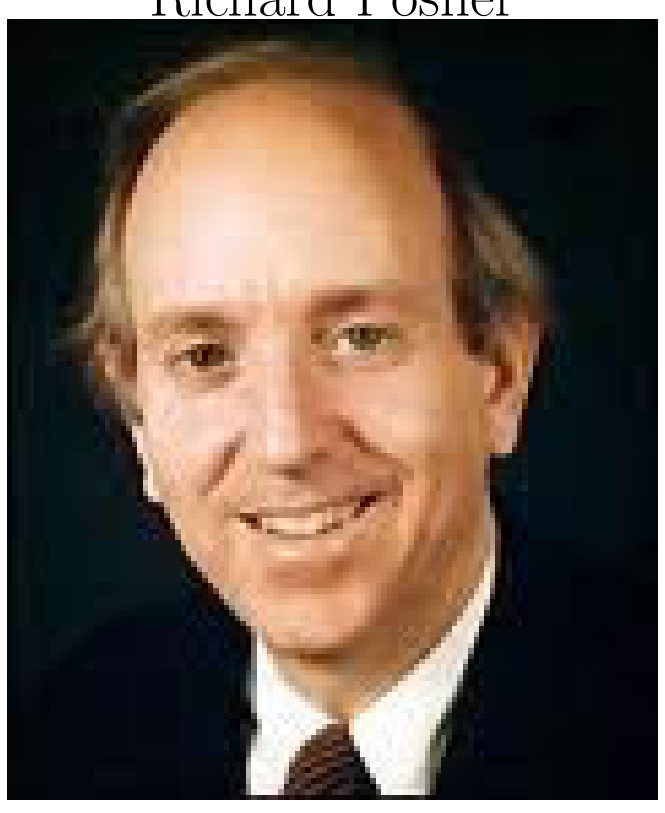


James Heckman

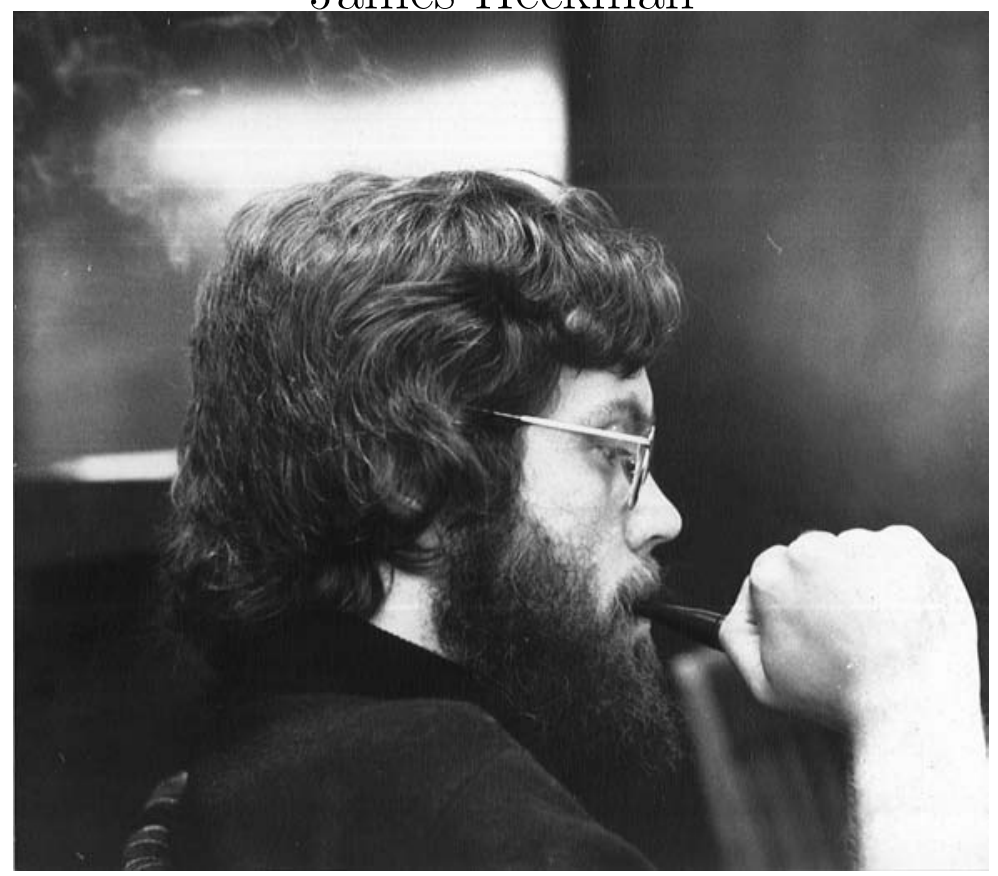

Ed Lazear

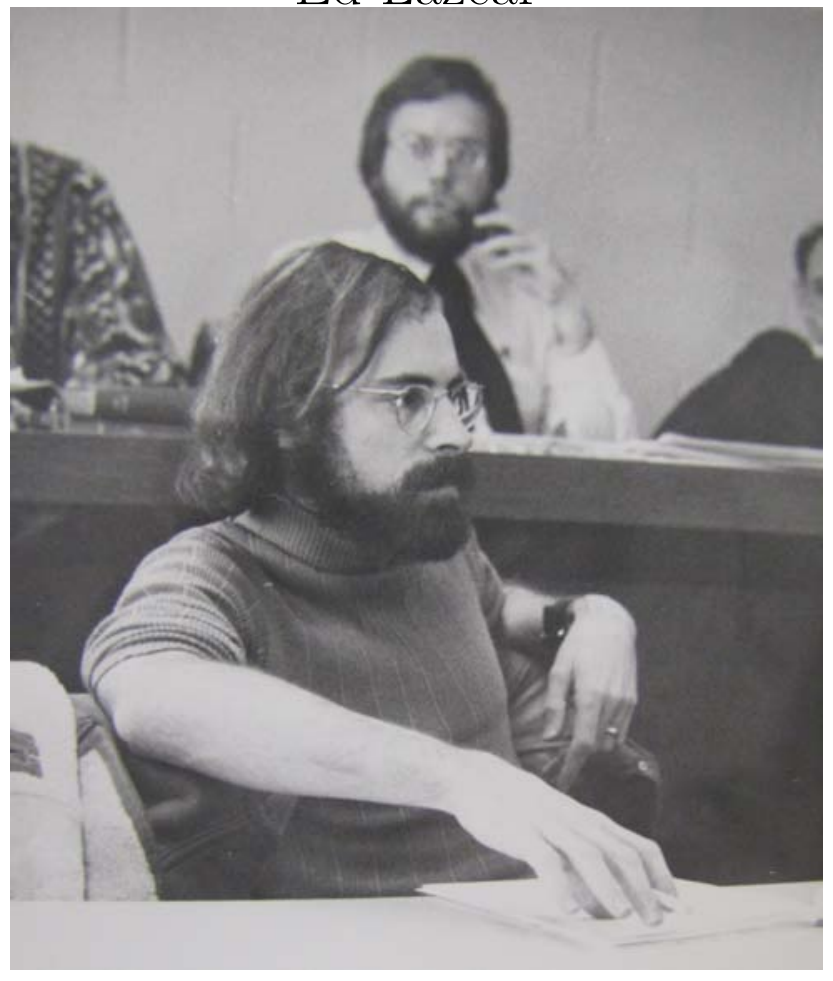




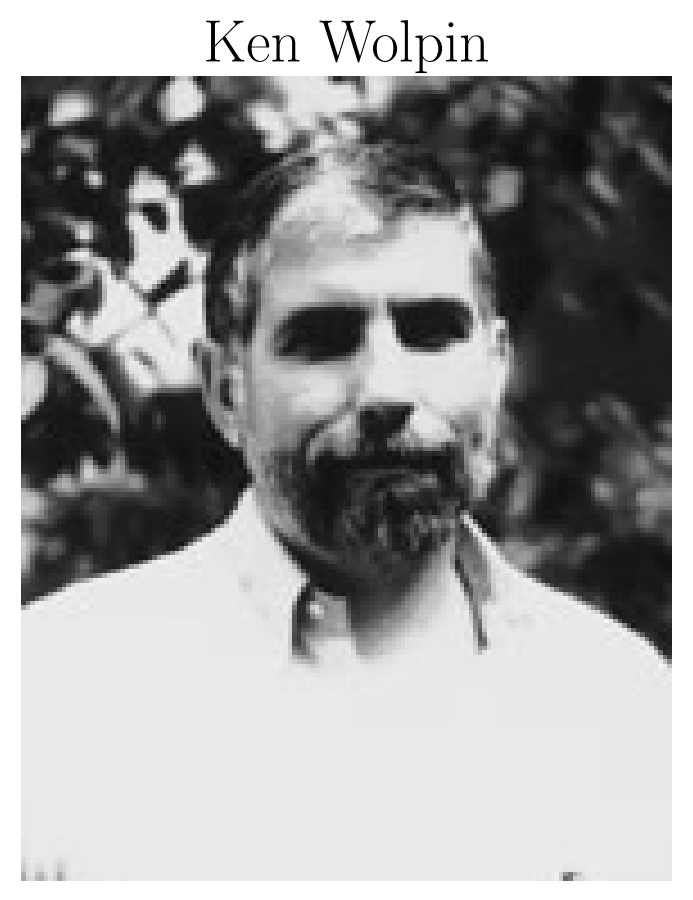

Jose Scheinkman

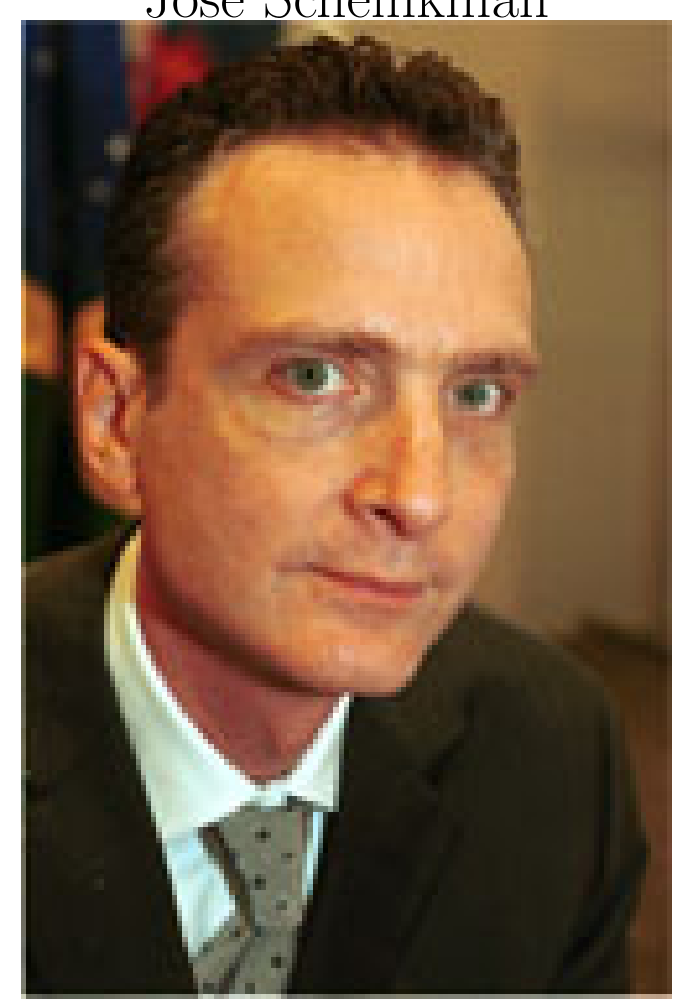


Buzz Brock

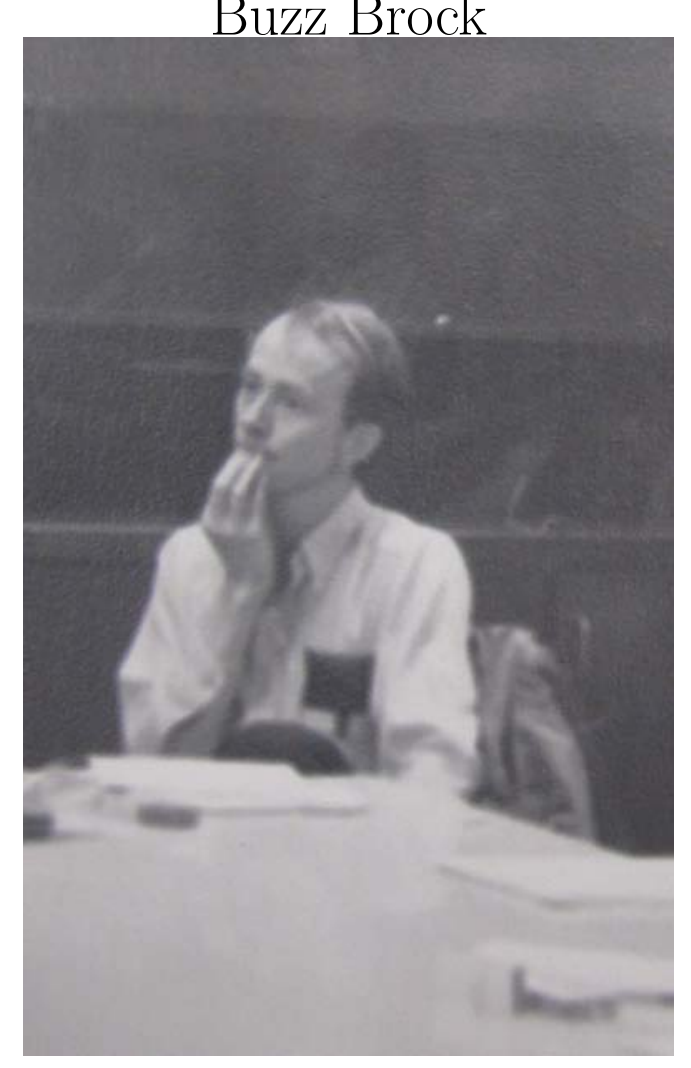

Denis Carlton

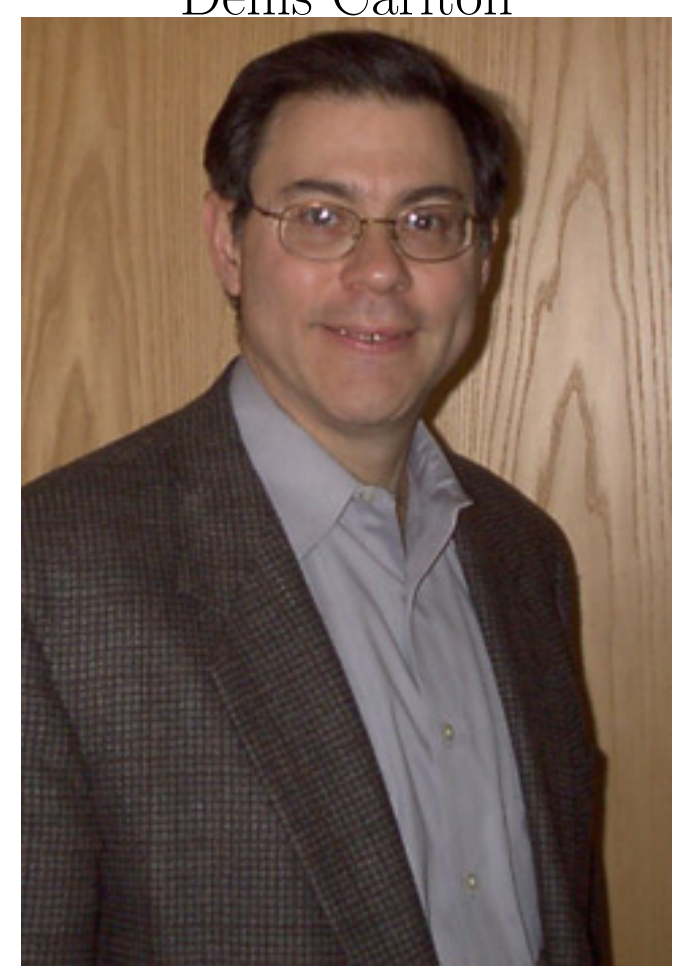



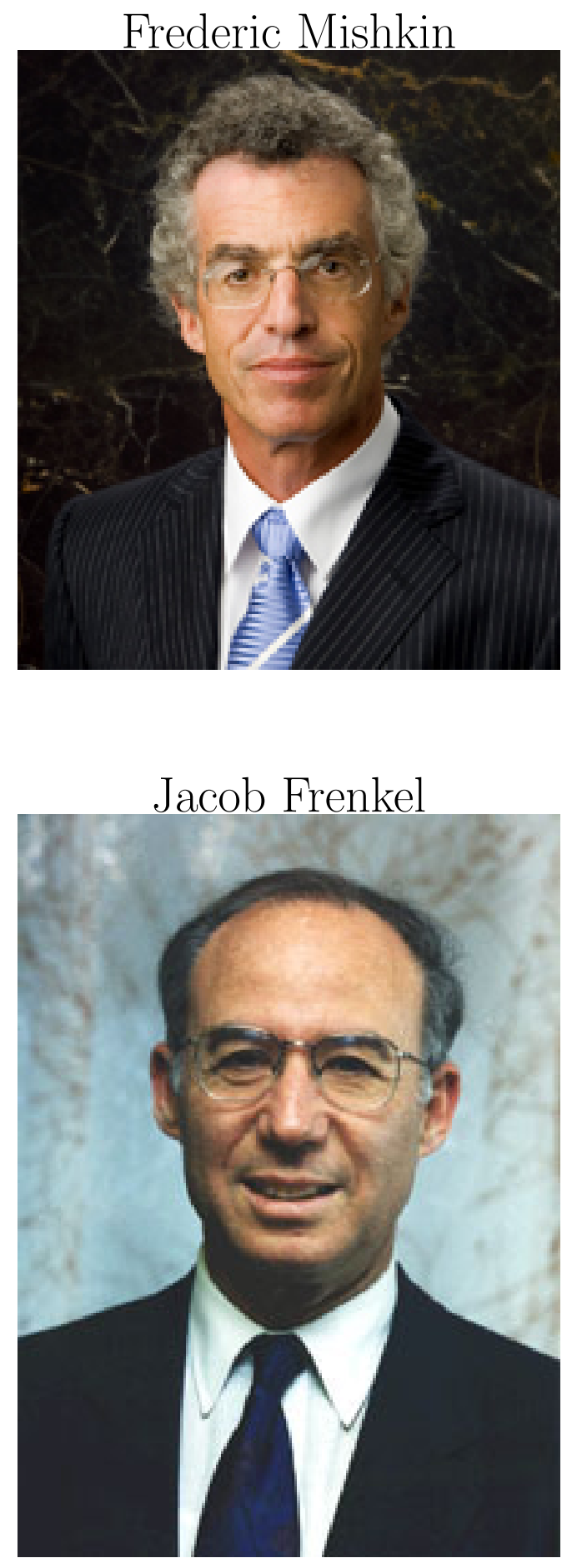

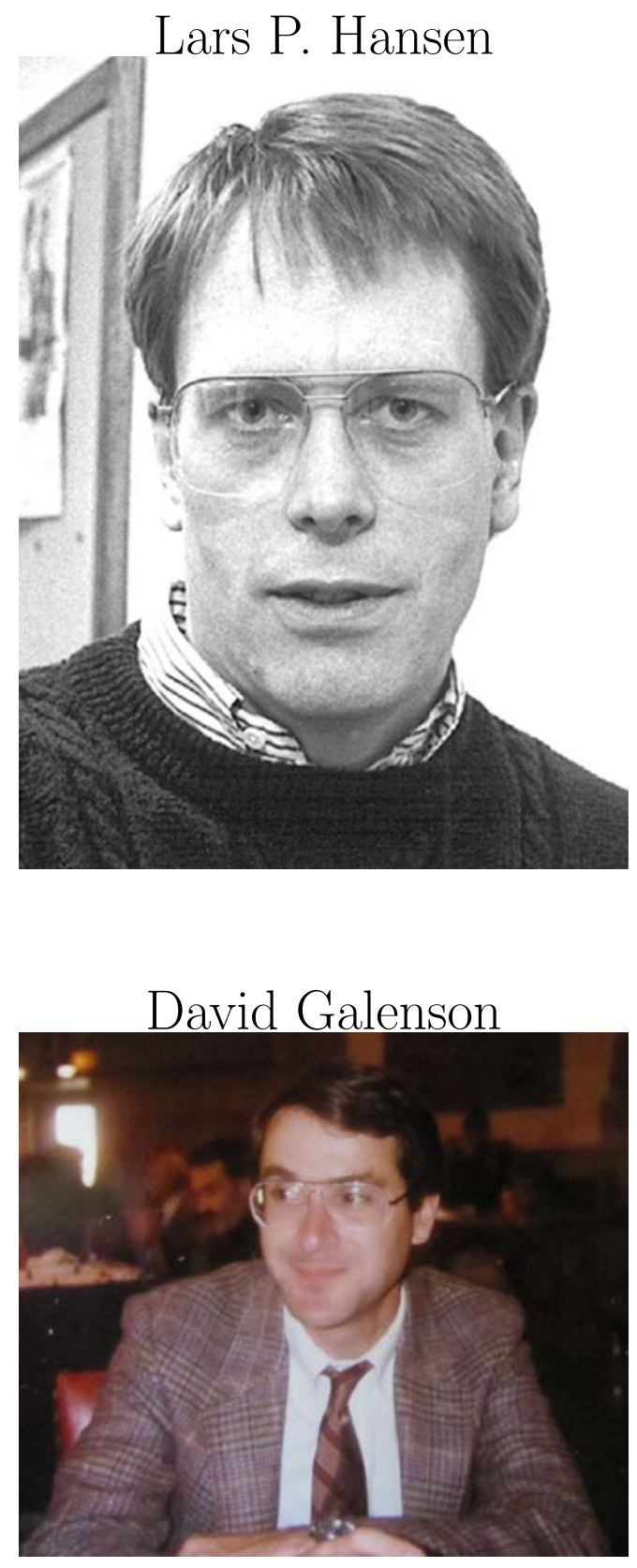

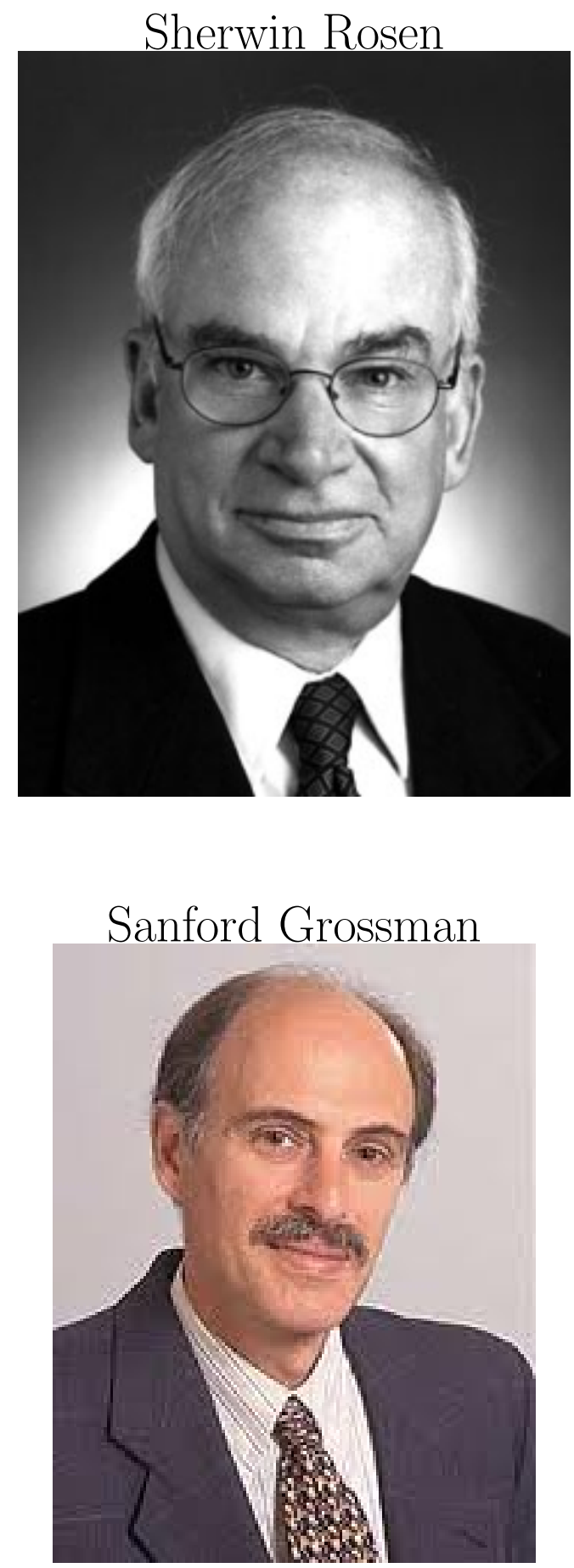

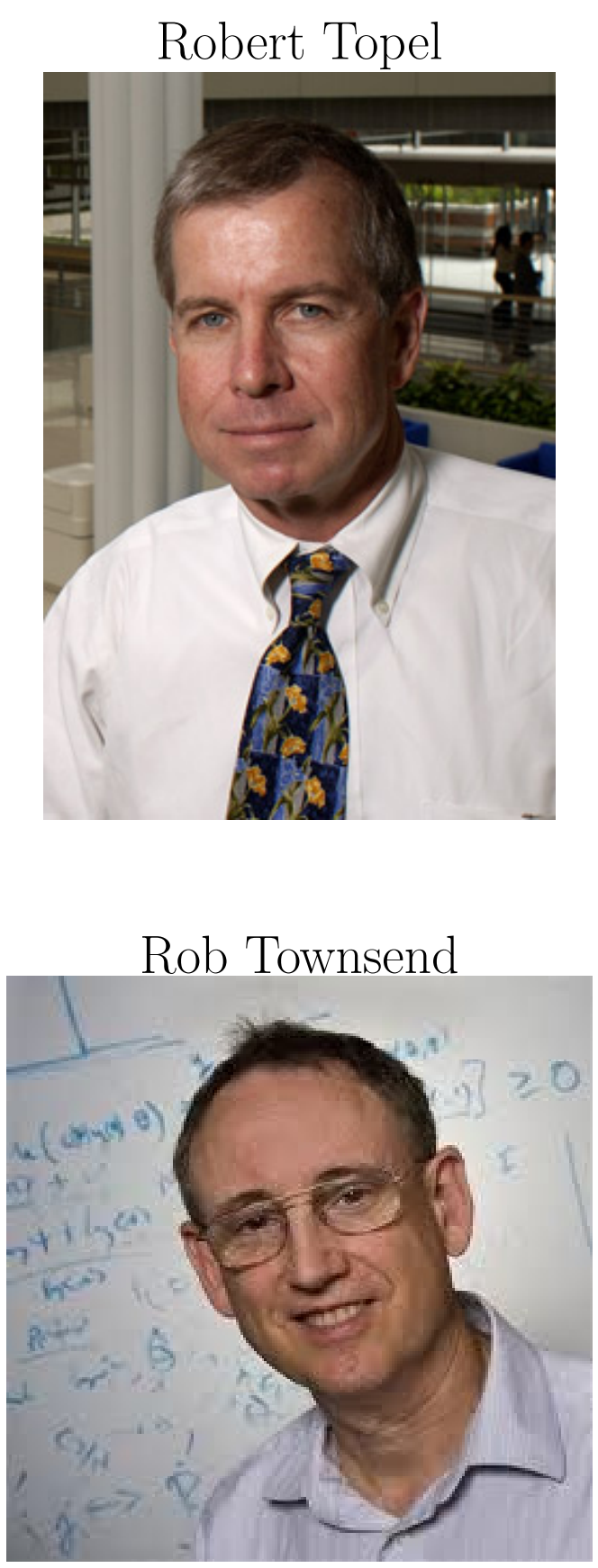

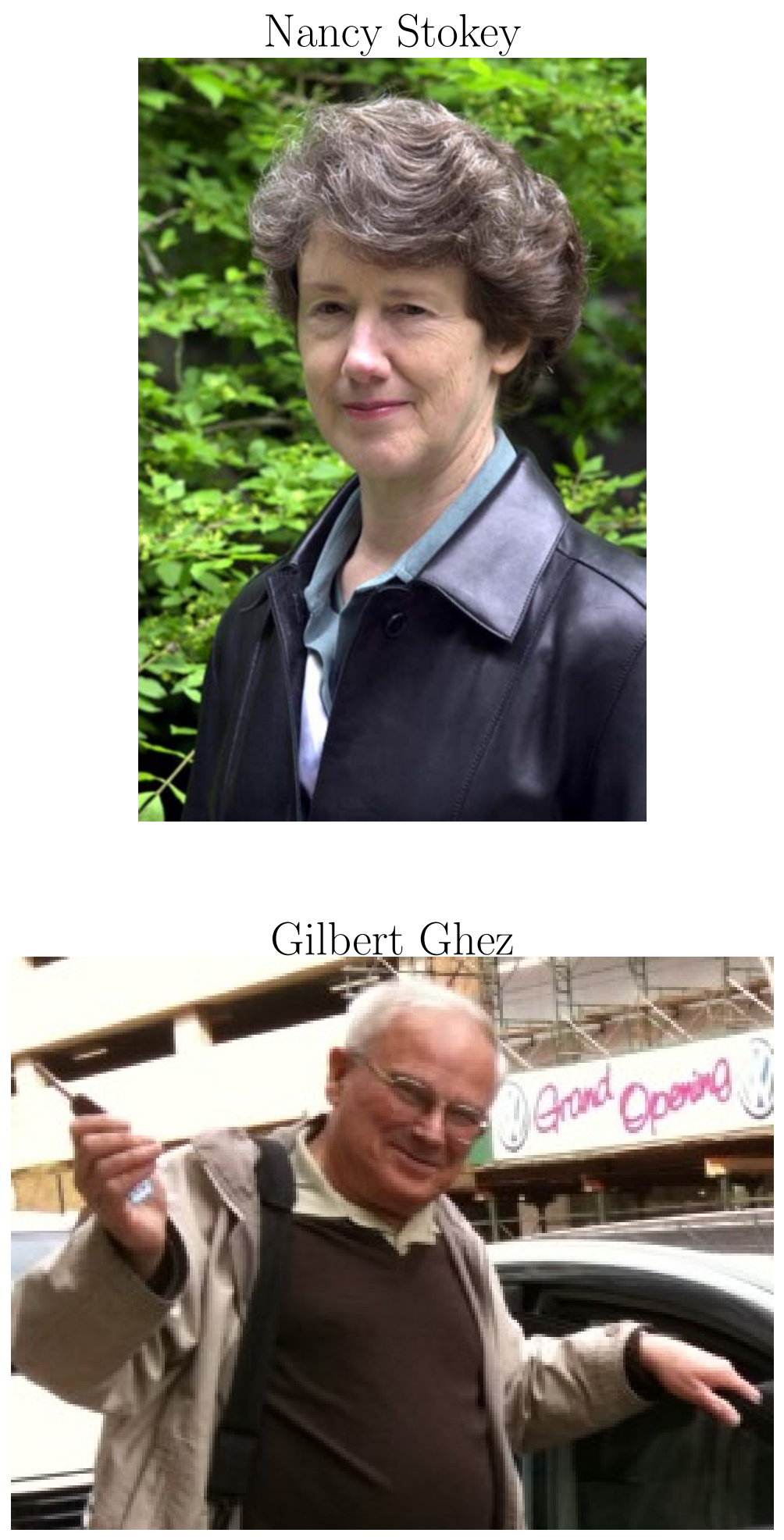

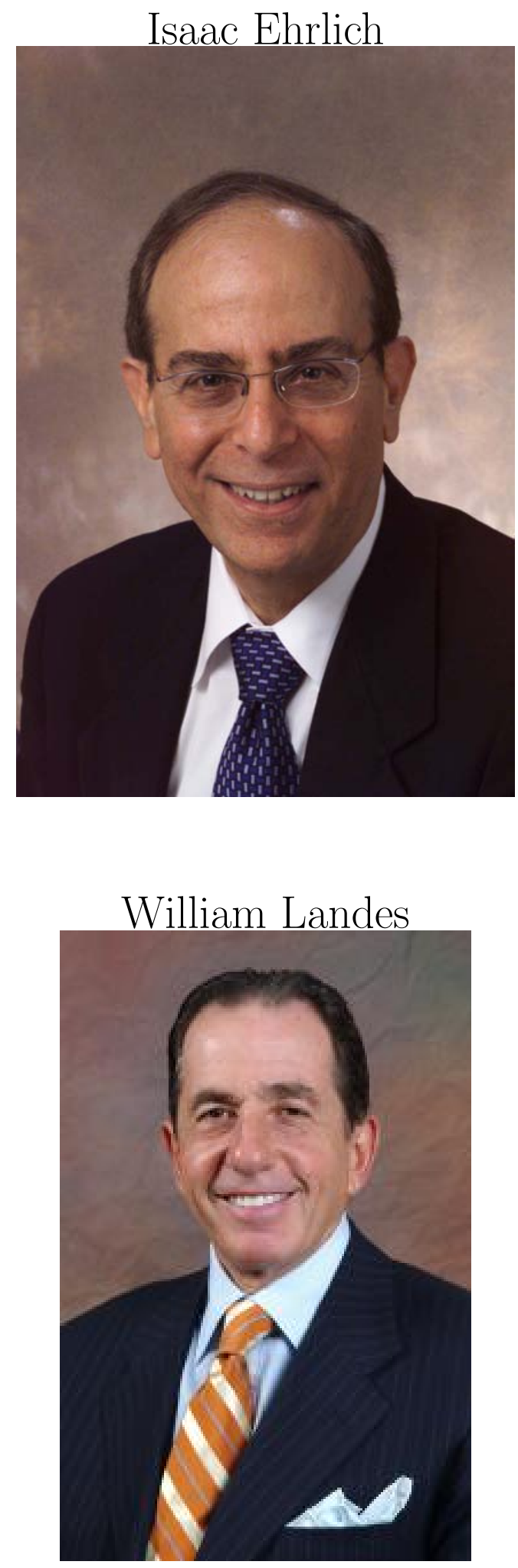
What, besides the intelligence of most of its members, made Chicago so distinctive, and why did it work? What Made the Place Tick? How Were People Assimilated into Its Culture?

A hallmark of Chicago economics, at least as it has been practiced when it is the most successful, is that it does not accept the division between theory and evidence that characterizes many other economics departments, even many leading ones. That unhealthy division of labor allows theorists to speculate without empirical discipline and empiricists to produce "tantalizing" or "cute" sound-bite empirical findings that make headlines but that are not guided by theory and that do not contribute to a larger understanding of society and the economy. Participants were asked to think big.

Chicago economists as a group, and especially in that era, avoid the schizophrenic separation of theory from evidence because of the ground rules of Chicago economics. 


\section{Three Ground Rules for Chicago Economics}

The first ground rule is that its faculty know and understand the corpus of economic theory — not just their specialty within the field. That we insist that our students and faculty speak a common language - the language of basic price theory and the economics of incentives - and that we can communicate these ideas clearly.

The second ground rule is that it views economics as a serious subject, tackling serious problems. Milton Friedman once described the seriousness of Chicago economics. He did not stay there, he wrote, "for the weather, but because his colleagues were engaged in the serious enterprise of understanding the world and not in getting their names quoted in newspapers." 
The third ground rule is that Chicago moves beyond selective and self-serving appeals to "stylized facts" to "illustrate" the theory and instead engage and promote the serious scientific task of creative collection and analysis of hard data, analyzing it with care, and linking the theory and evidence. Chicago does not devalue the hard empirical work that produces hard evidence and rigorous economic theorizing. 


\section{Need to Distinguish Chicago Economics from the "Chicago School"}

\section{Aspects of the Chicago Economics}

(a) High quality of the faculty; high level of integrity; mistakes were made, but if anything over most of the period mistakes were in NOT appointing people, not in appointing people.

(b) Price Theory as Lingua Franca

(c) Belief That Economics Was Solving Real World Problems and was not intellectual escapism

(d) Integrating Theory with Data and Hypothesis Testing

(e) Intellectual Intensity and Honesty; Humility More than just being smart or being clever, but that is important too. (Friedman's letter to me about Henry Schultz — Friedman said that when he was young he thought Schultz was not very smart and had a low opinion of him. But, over time, he realized how rare Schultz's intellectual honesty was — how much he wanted to know the truth, to be corrected if he were wrong.) 
Chicago Economics Emphasized Intellectual Honesty and Humility

Although the painting is much later, the picture would be a good image of Chicago then and now.

"Check That Ego at the Door!"

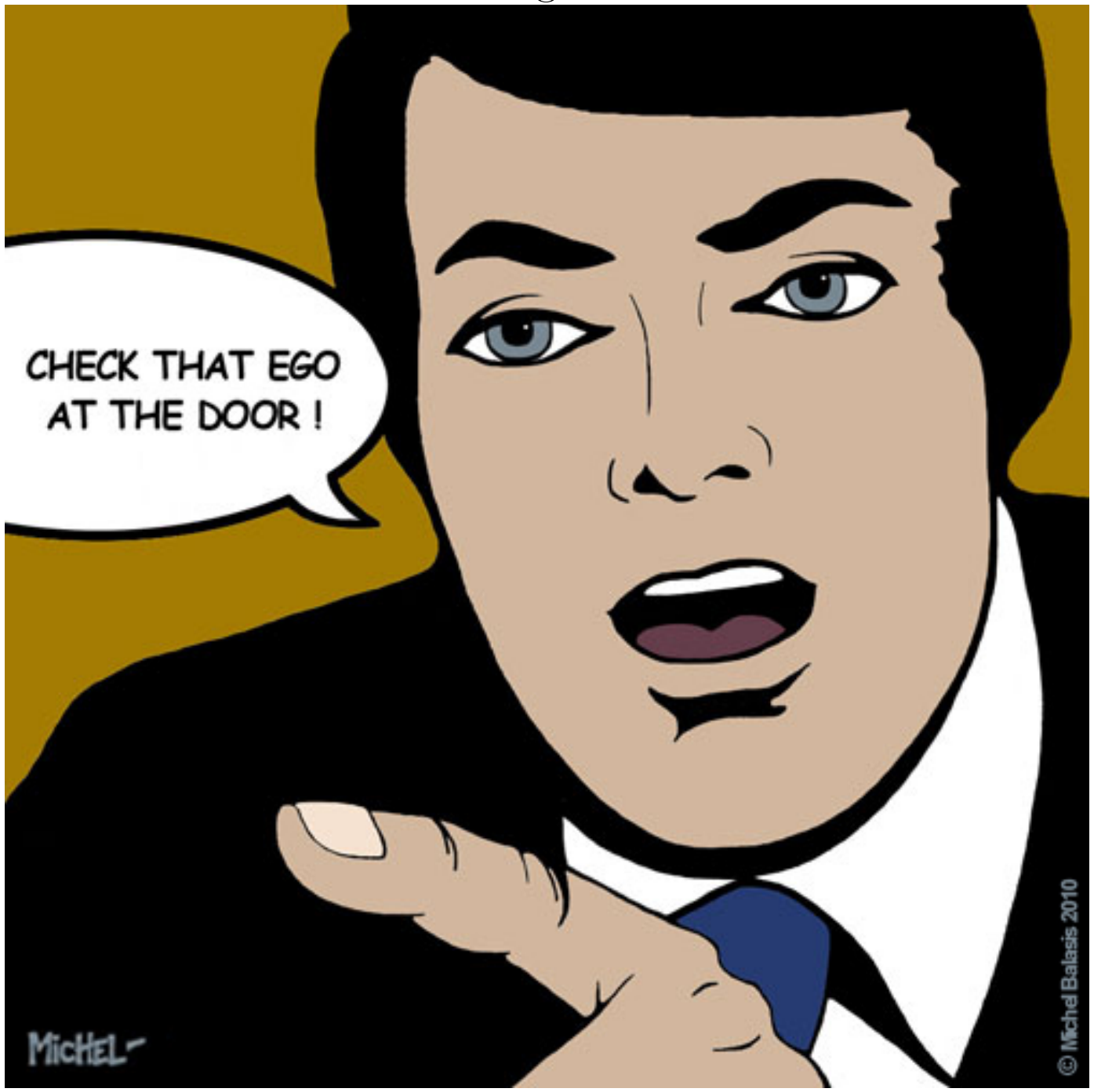


Friedman and Stigler Workshops Were the Iconic Ones

Stigler's Better Documented Because George's Hobby Was Photography 


\section{Stigler Workshop Photos}
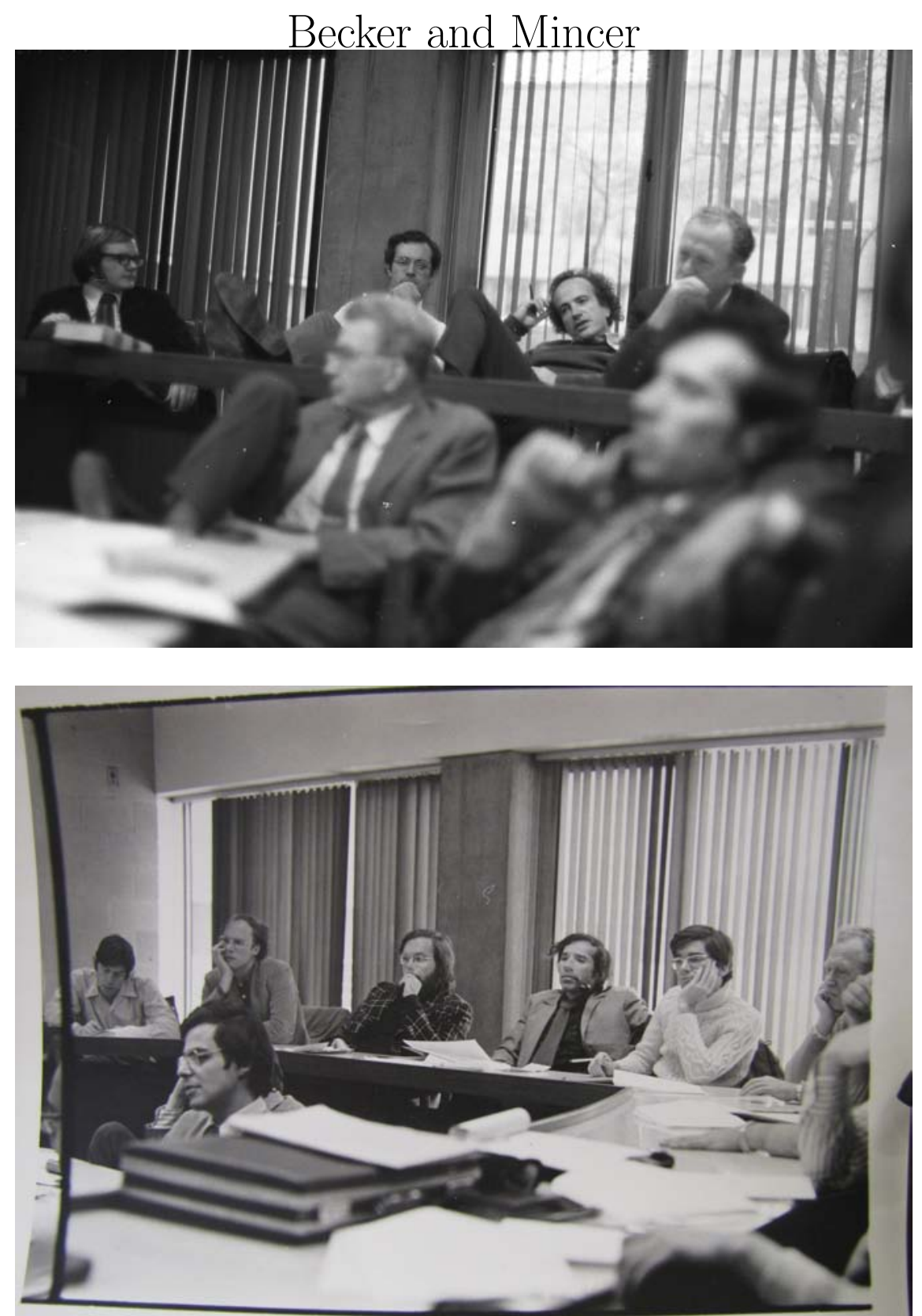


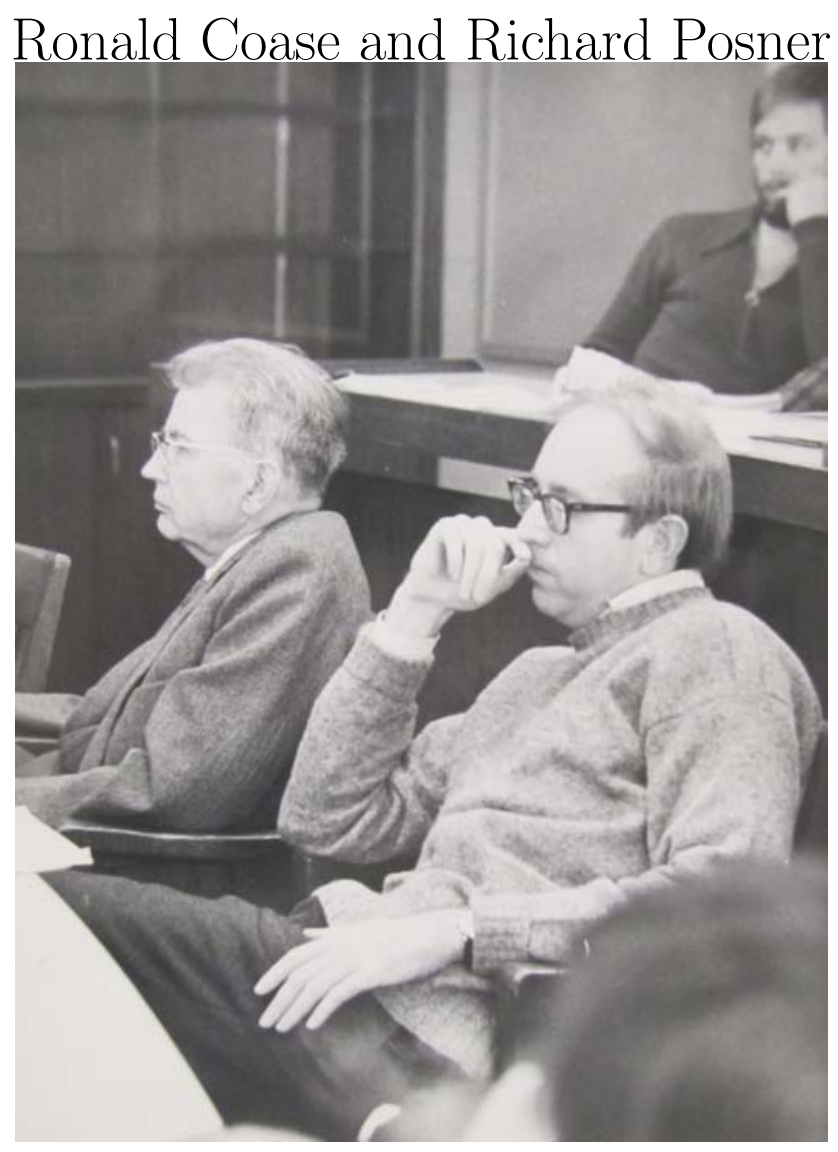

Reuben Kessel

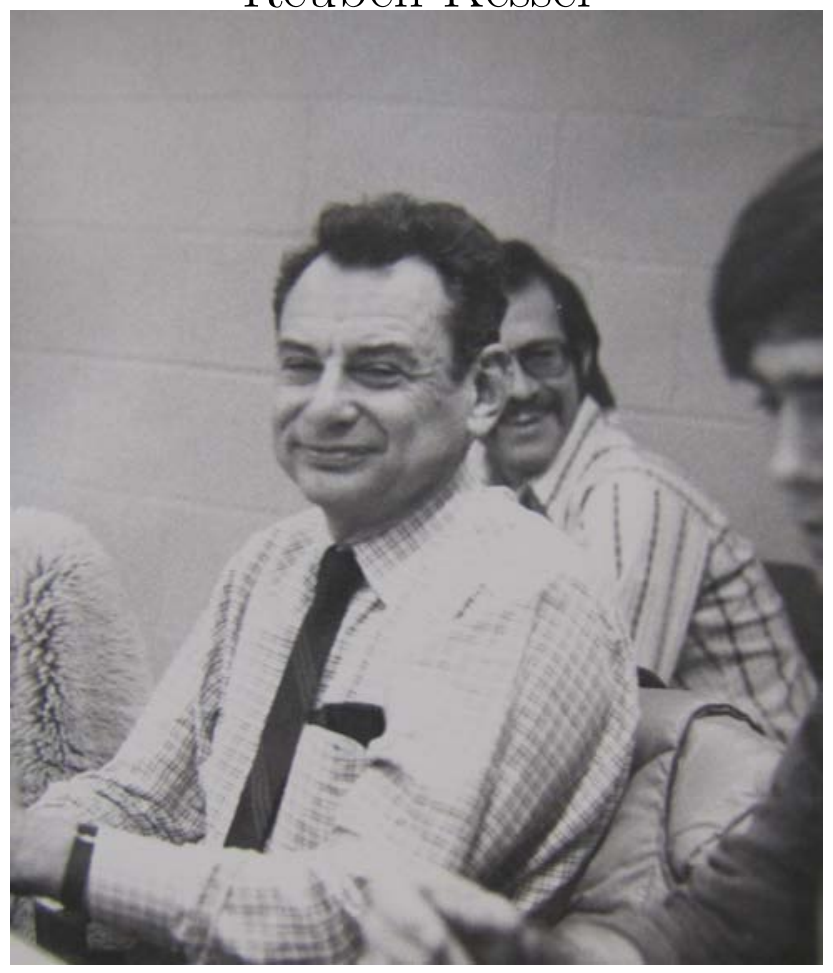




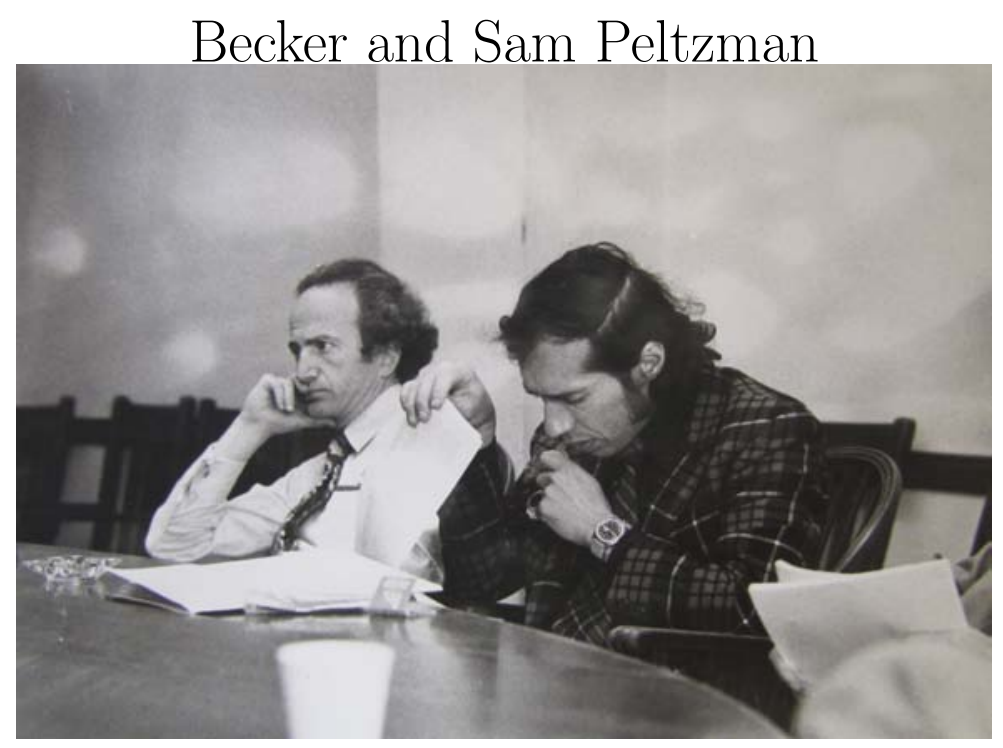

Ed Lazear

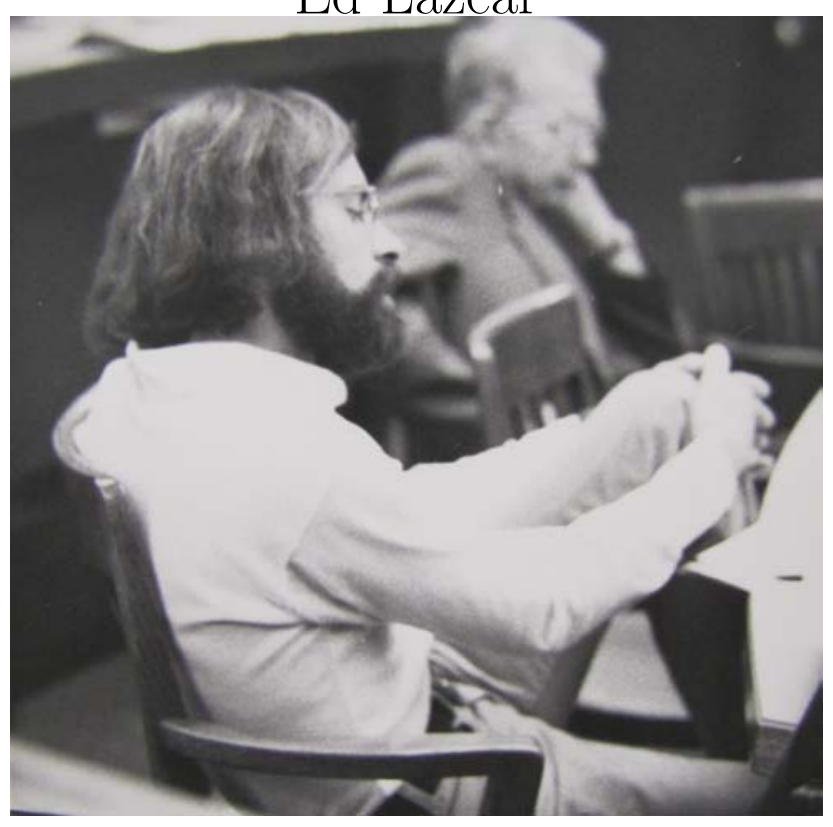




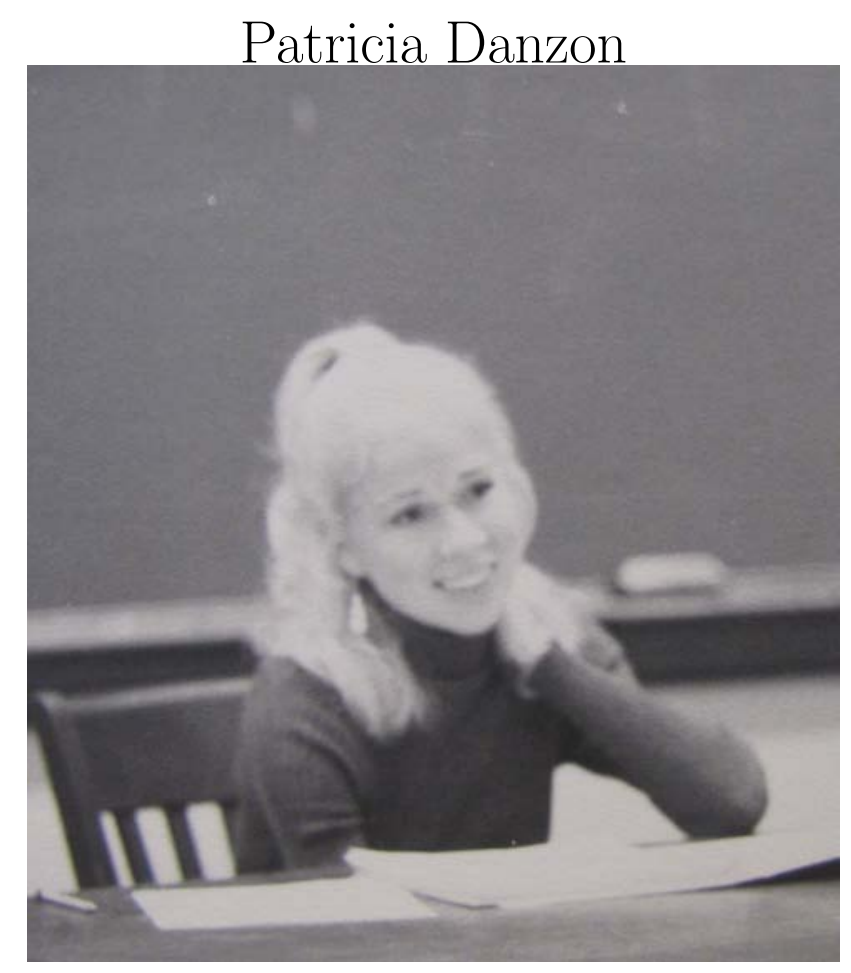

Buzz Brock and Steve McGee

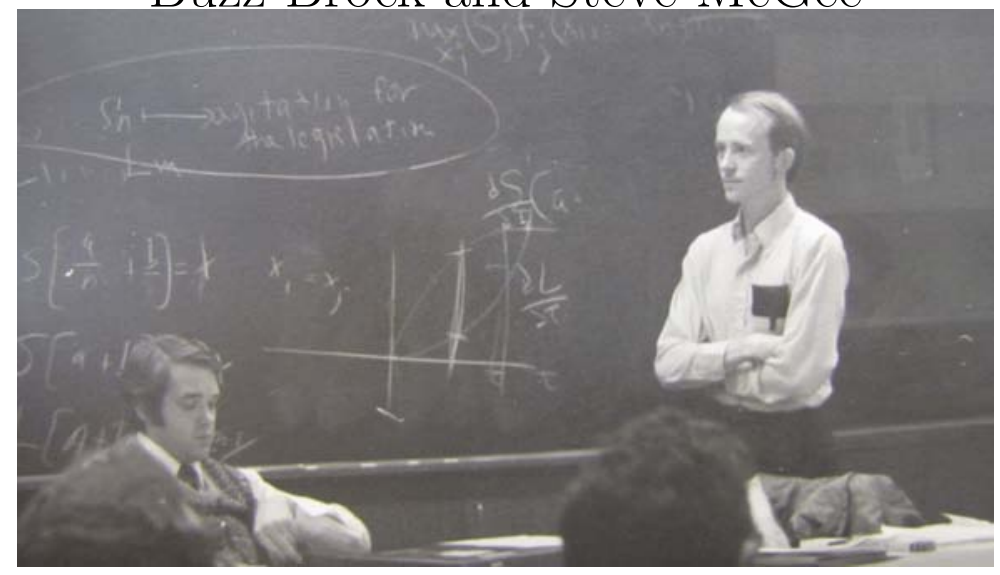


Legendary Workshops
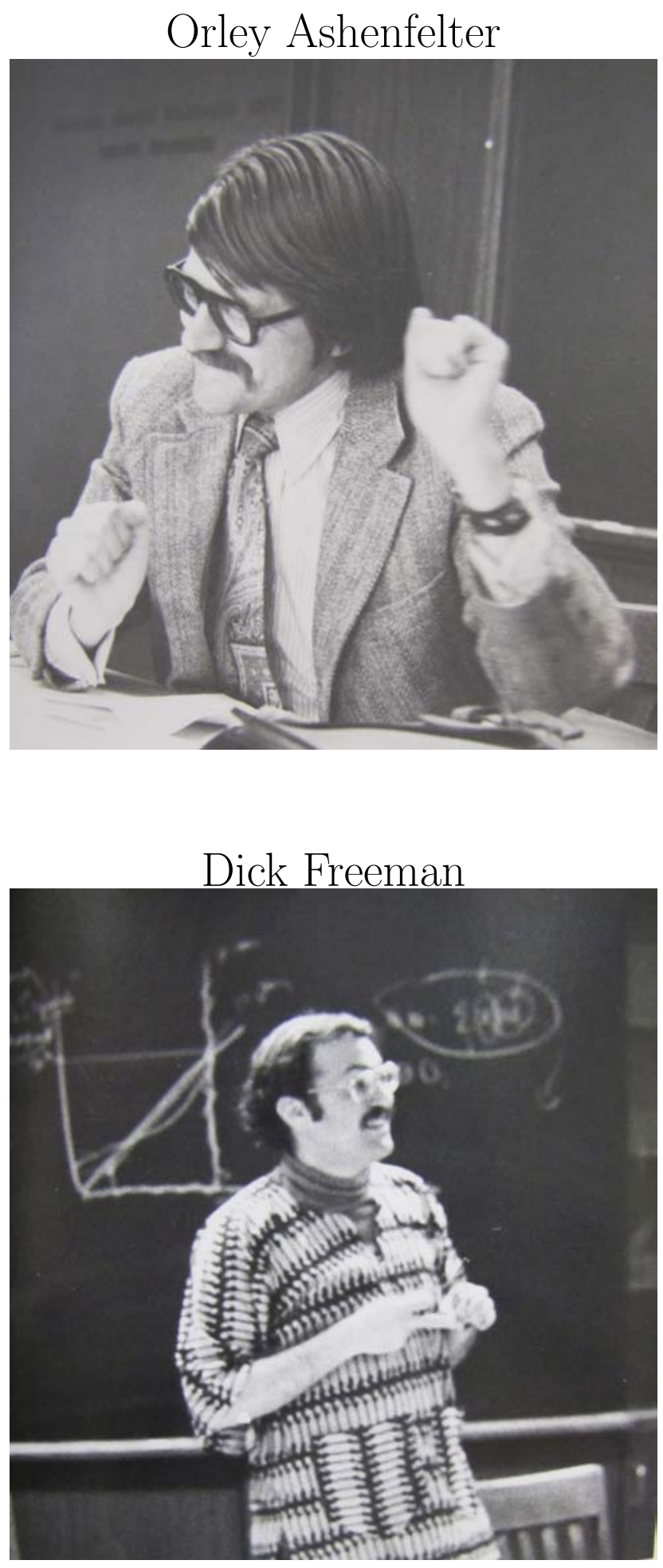


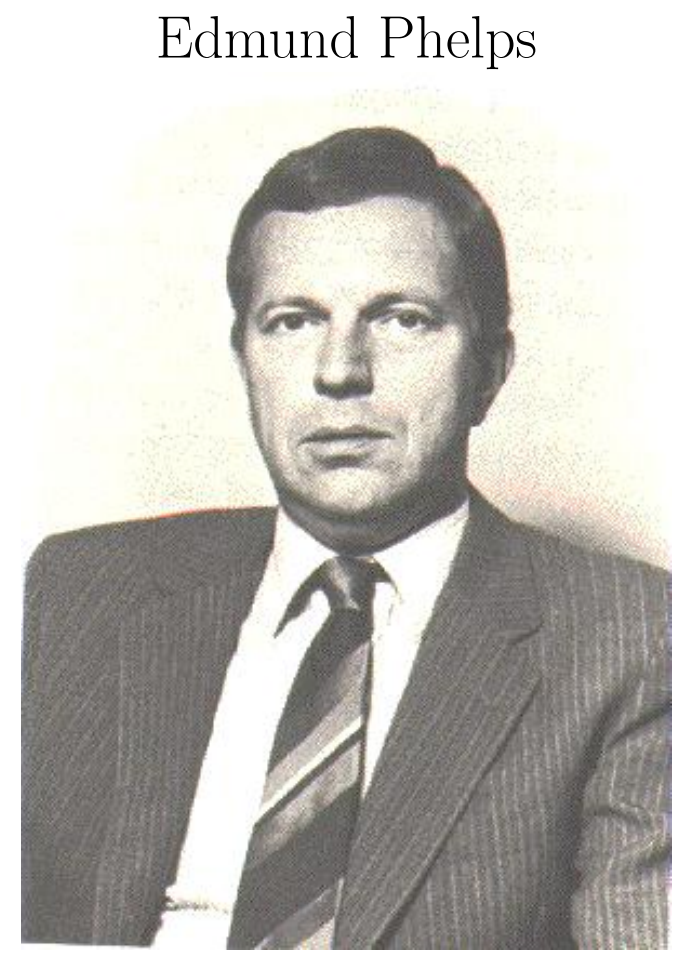


"Around 1975, Phelps was invited to speak at Chicago in George Stigler's legendary blunt-talk workshop on industrial organization. We had been colleagues at Columbia. His topic was the role of altruism in economics. At that time most in Chicago ruled out social interactions and any approach but the methodological individualism of agents interacting only through markets. Altruism and social interactions were not on the table in mainstream Chicago economics. A pantheon of Chicago price theorists was in attendance including Gary Becker, Reuben Kessel, Richard Posner, and George Stigler among many others."

\section{"He started his workshop with D.H. Robertson's}

questions: 'what is it that economists economize?' The answer: 'love, the scarcest and most precious of all resources' (Robertson, 1956)."

"For the next hour and twenty minutes Phelps took a pounding from the infuriated methodological individualists. (But not from Gary Becker, who had just written an early paper on altruism and social interactions.) The outrage and outpouring 
of anger expressed by the assembled participants brought to my mind the performance of Nikita Khrushchev at the UN in 1961 when he pounded the table with his shoe.

"Becker and I supported him, but against fierce opposition. George pronounced that Adam Smith had written two books, but only one was worth reading - Theory of Moral Sentiments - and the economics of empathy were off limits. Phelps sat back and rolled with the punches, and gave back all that he got and more. On the way back to my office, crossing the Midway, Phelps laughed and said, 'I wanted to show the group at Chicago that there is more to economics than price-quantity plots."

"Unknown to Phelps, Becker was doing exactly that as he Beckerized the Department of Economics." 
Becker at Chicago

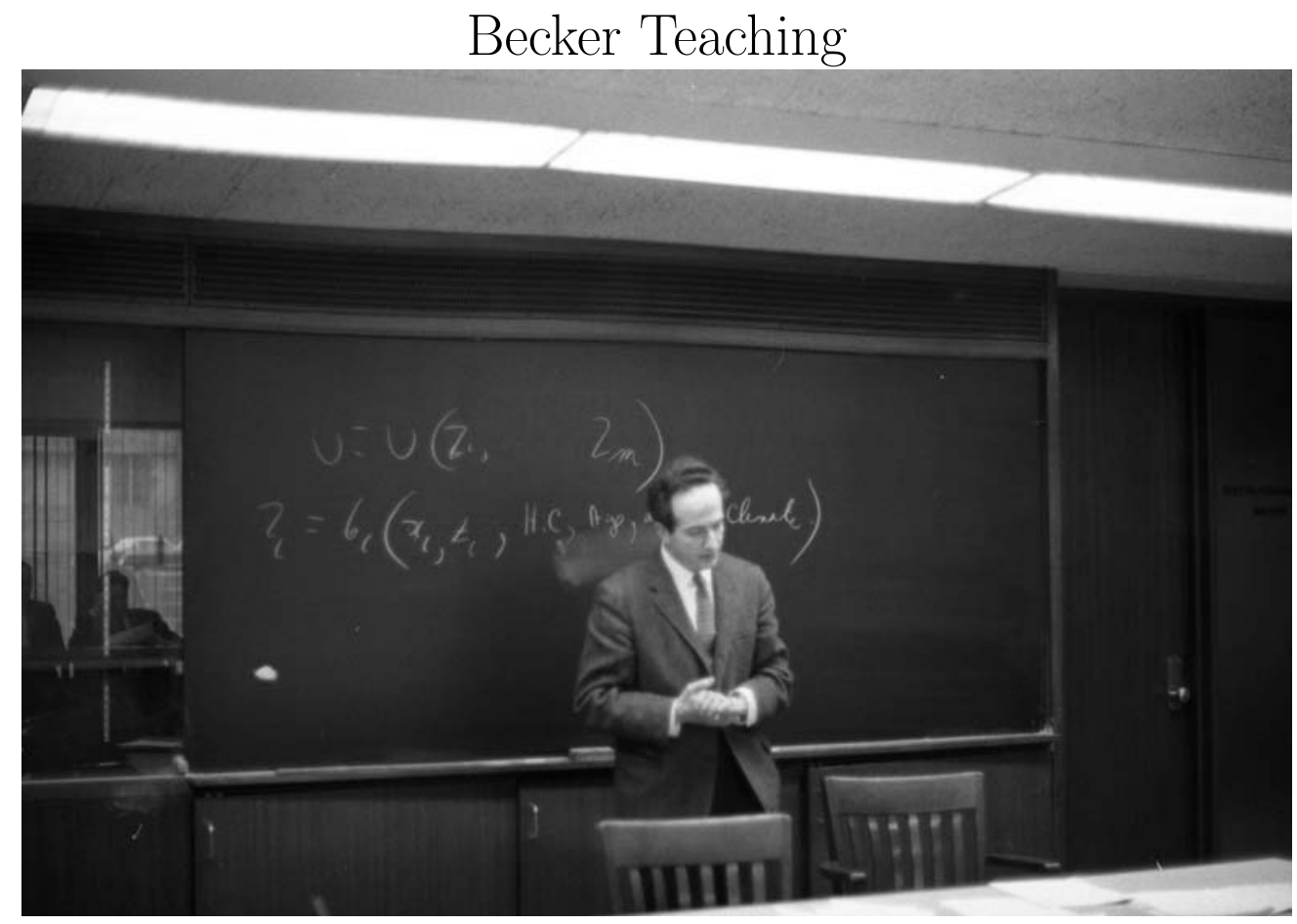

Human Capital Lecture

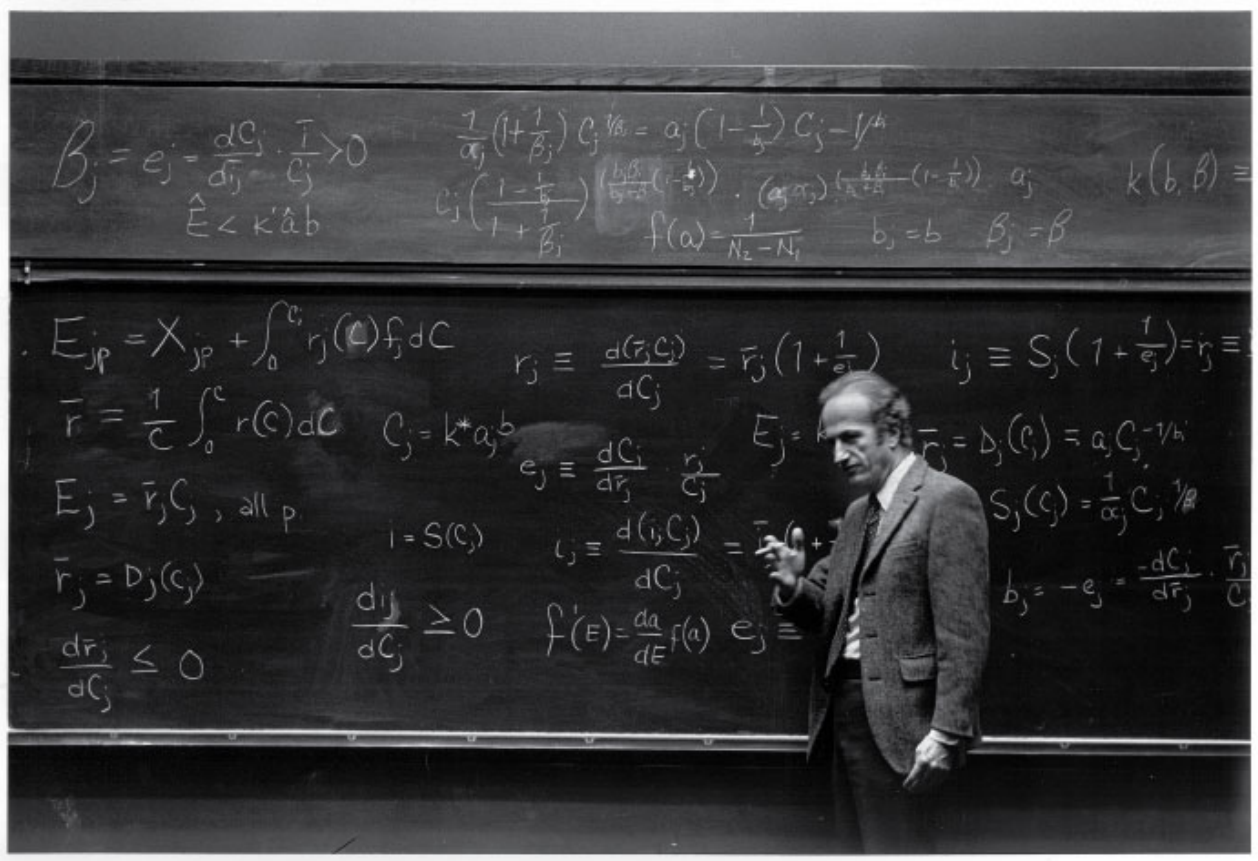




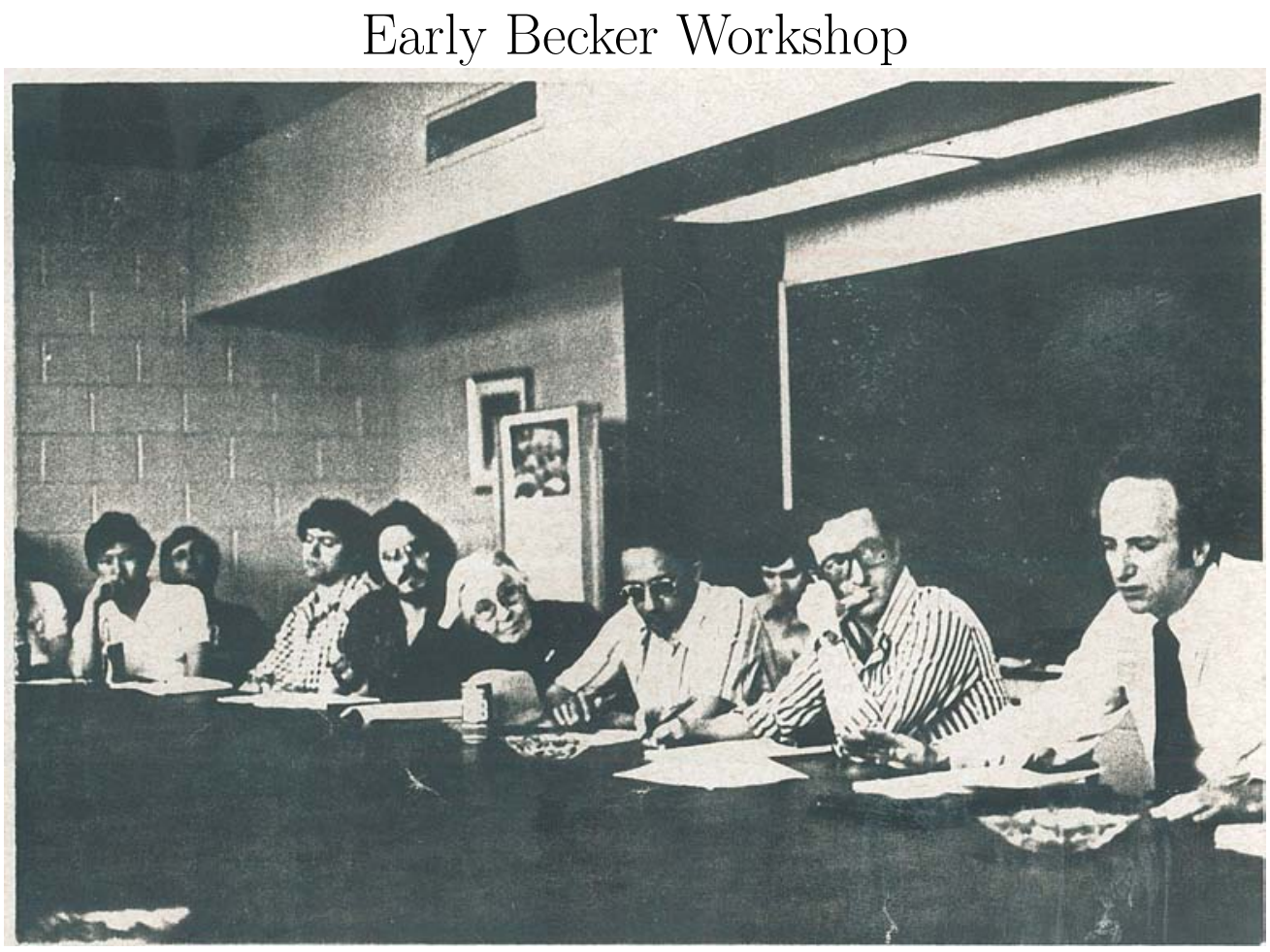

He was kinder and gentler, less structured in his workshops than Friedman and less brutal than Stigler — but still featured blunt talk. 
The Chicago School of Economics: Distinguish from Chicago Department of Economics — Easily Confused

Question:

1. Is There a Chicago School of Economics? (A Midwestern version of the Manchester School?)

2. When Did It Emerge? (1946 - By all accounts became a recognized group of scholars with the arrival of Milton Friedman; There were earlier precedents. Douglas commented on how the atmosphere had changed.)

3. Becker's role in the Chicago school above and beyond his role in the department. 


\section{Chicago School}

Use of Price Theory;

Associated with neoliberalism;

Focus on markets;

A belief that free markets promote democracy;

Václav Klaus contributed to this

Politically conservative (Stigler wrote that economics was intrinsically a conservative field if only because economists respected budget constraints and tradeoffs - at least most economists.) Lots of economists did not agree.

Many People at Chicago were not Chicago School. Were strongly into Chicago economics, independent of its politics.

Closely associated with Chicago economics and especially after Capitalism and Freedom was written.

(Story of Milton and Rose Friedman in the interview.) 
Friedman, Stigler, and Director at First Mt. Pelerin Society

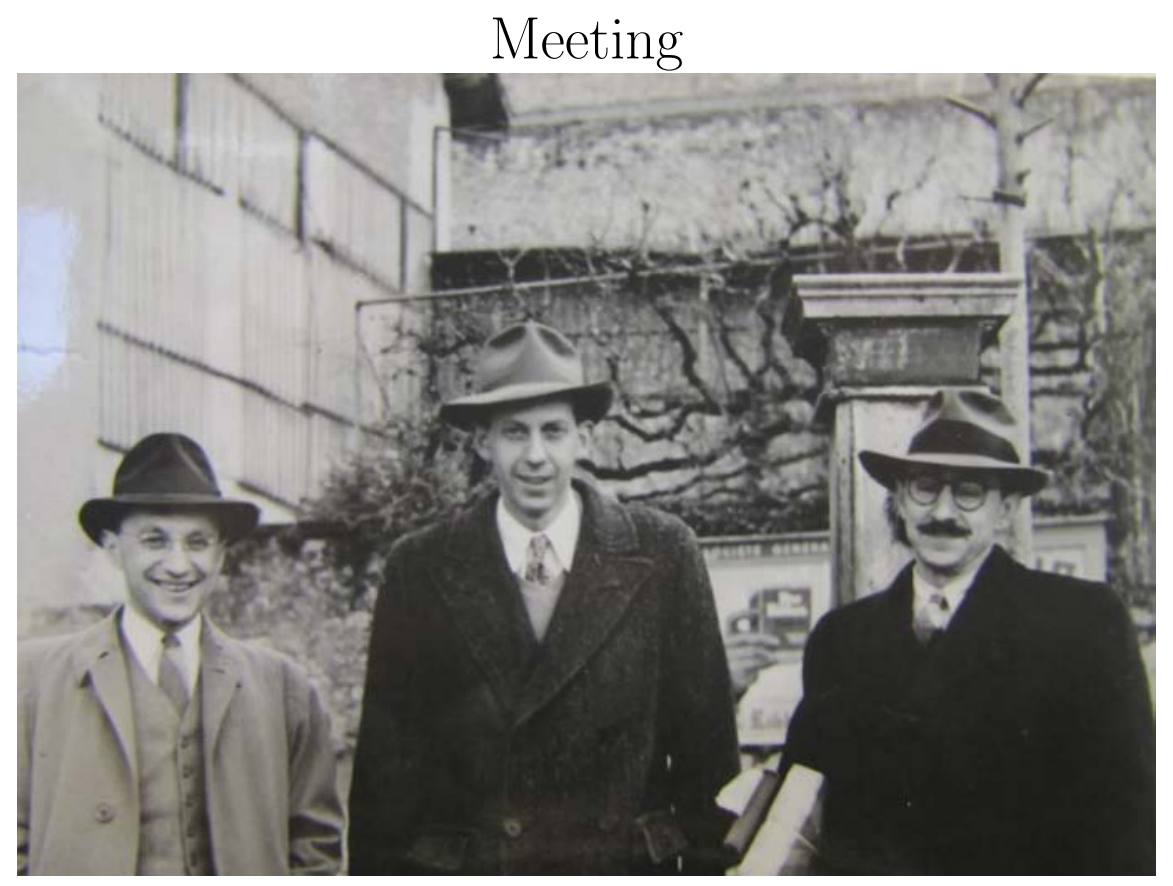

Frank Knight

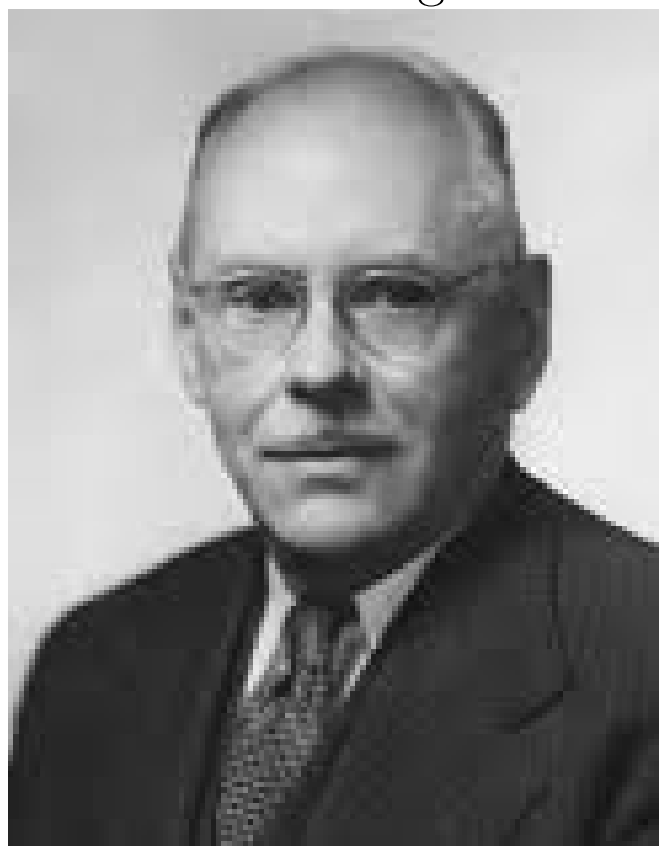


Friedrich von Hayek

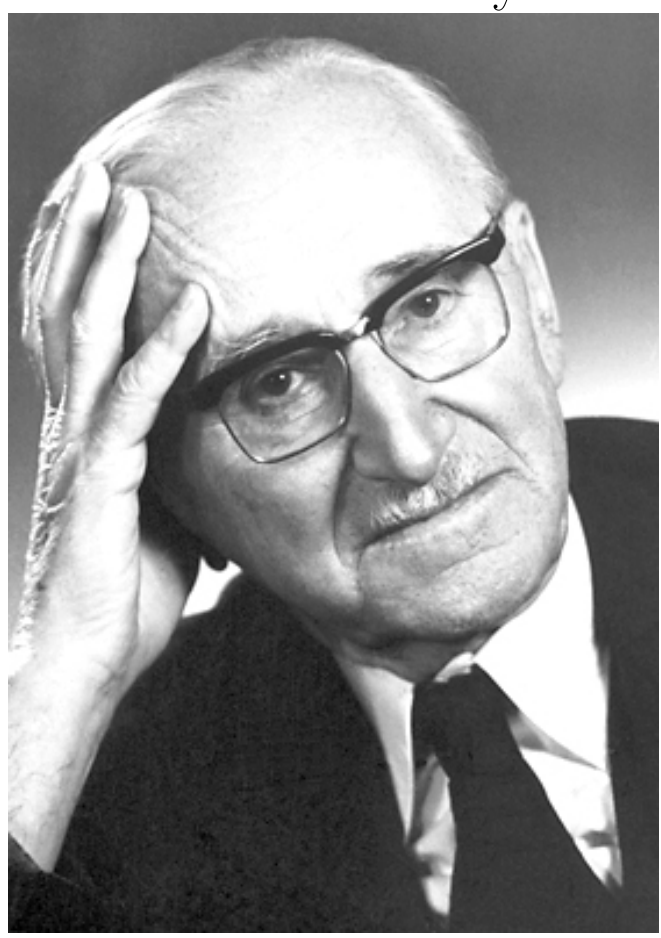

Fritz Machlup

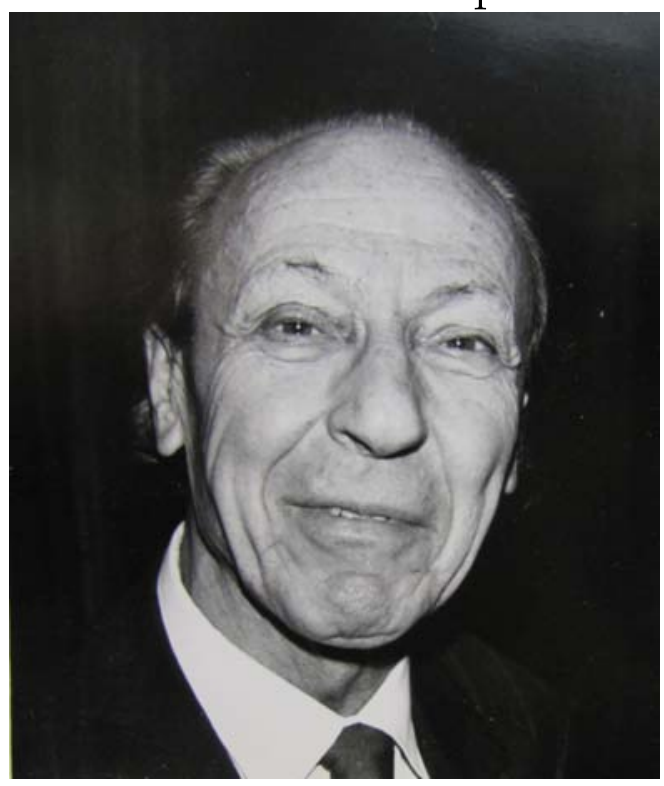



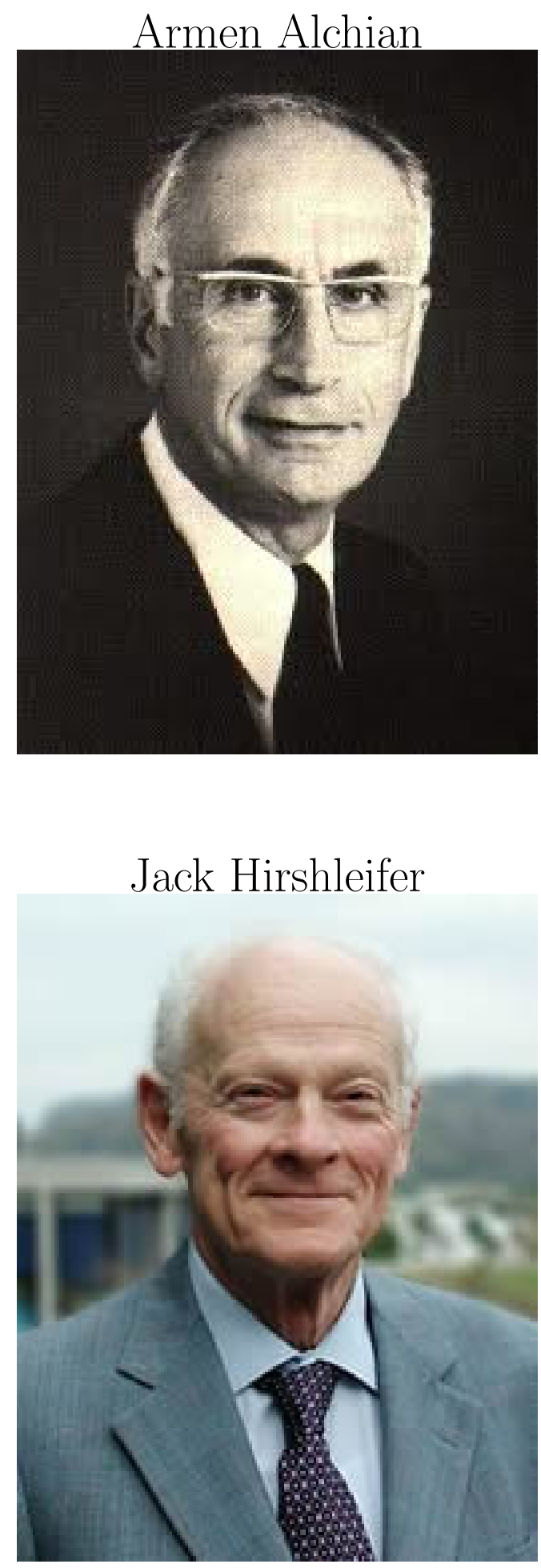
There are continuities, but (a) concept of "Chicago School" emerged only in 1946 - Arrival of Milton Friedman - Before Them Excellent People with Diverse Views

James Laughlin

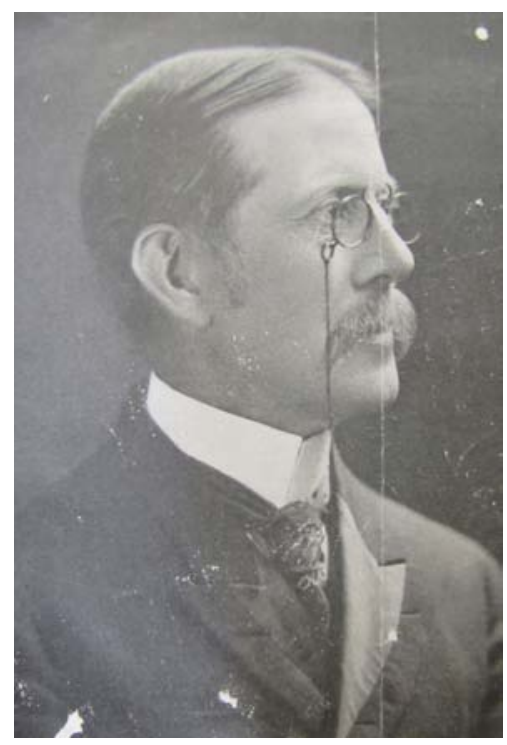

Jacob Viner

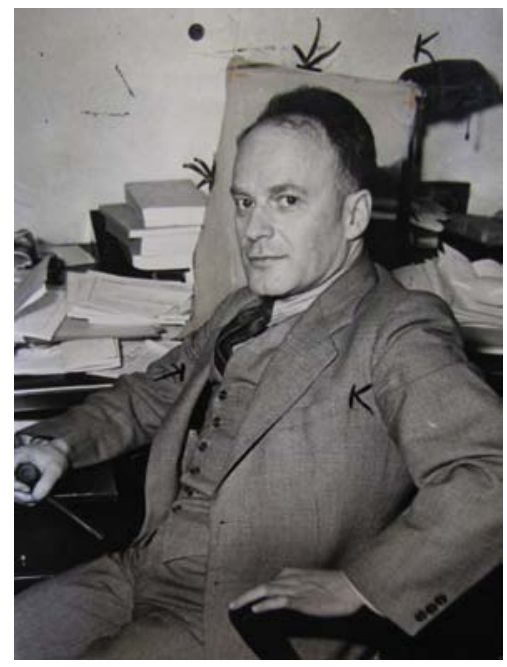

Thorstein Veblen

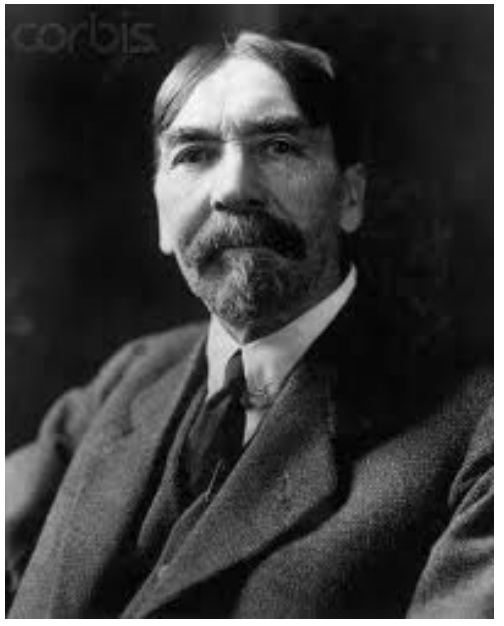

Frank Knight

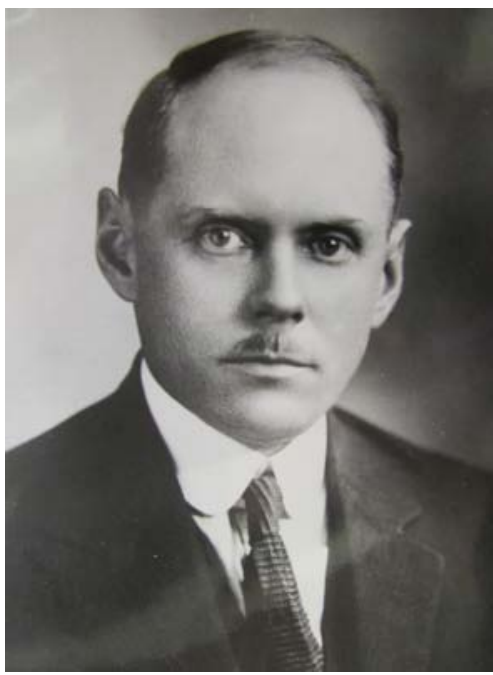

Henry Simons

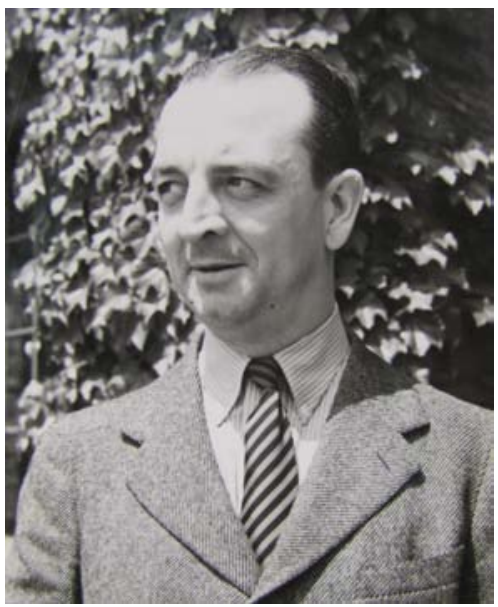

Henry Schultz

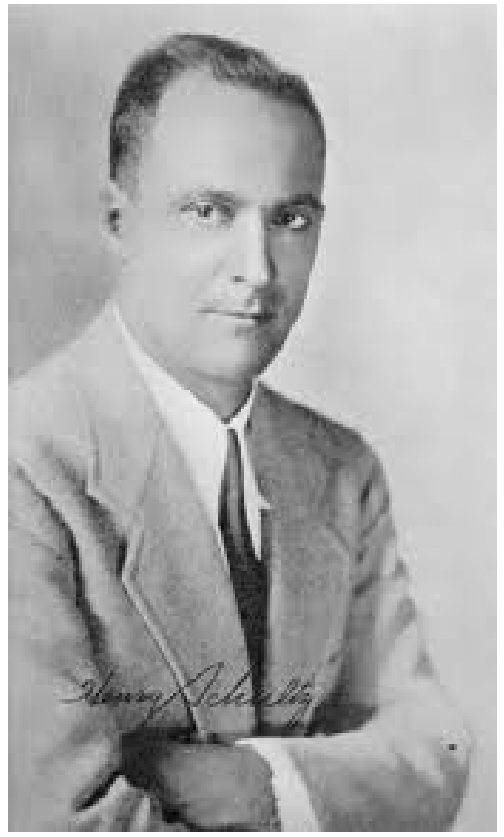




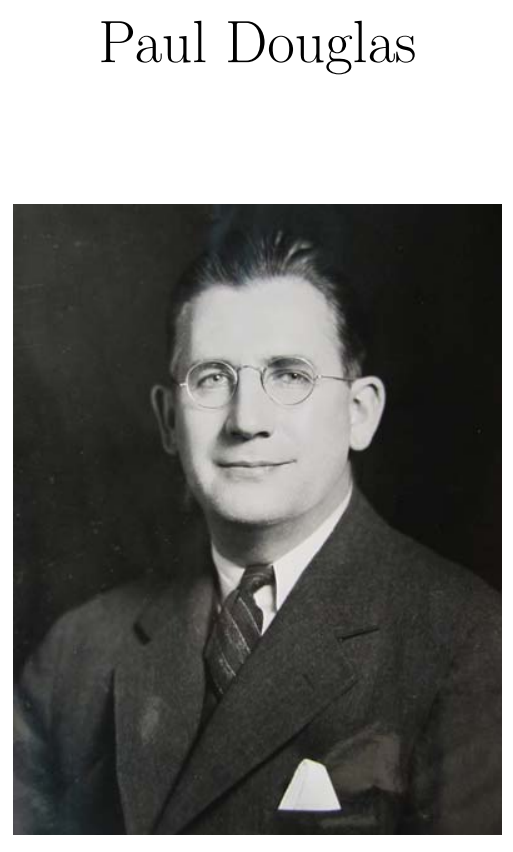

Lewis

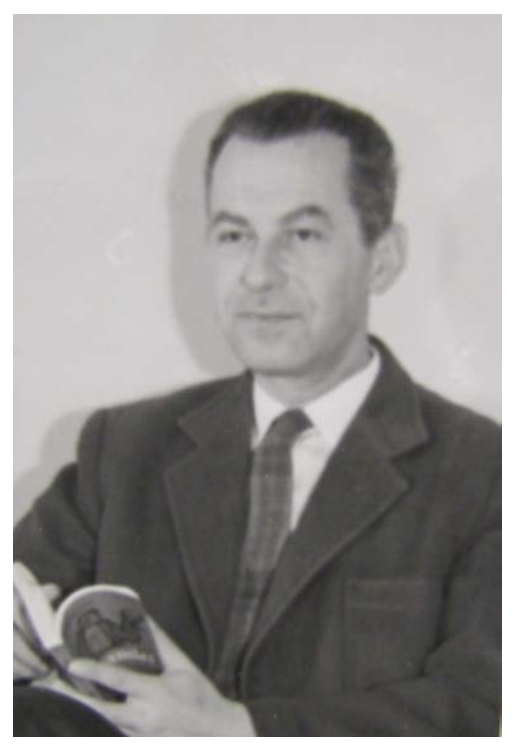

Oscar Lange

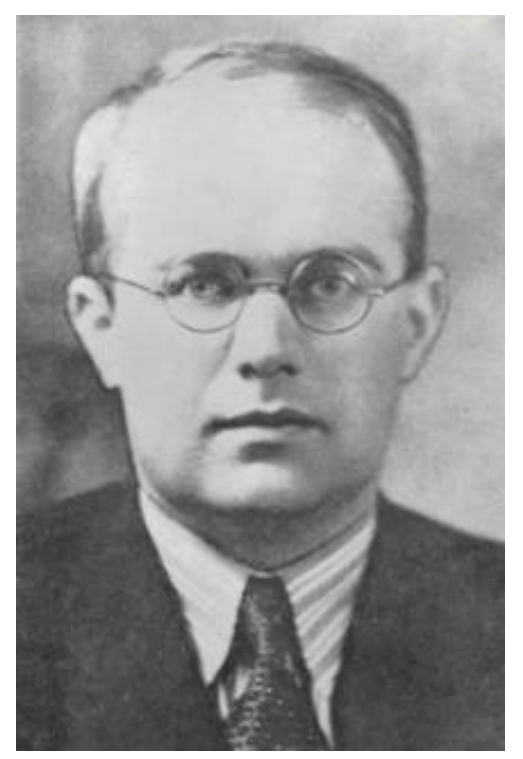

T.W. Schultz

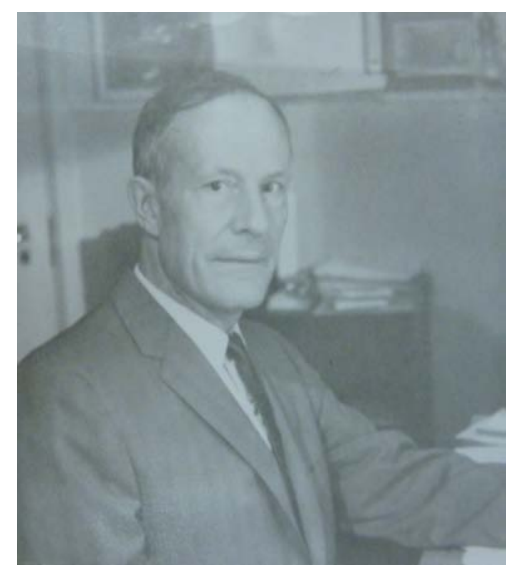

Lewis and Viner

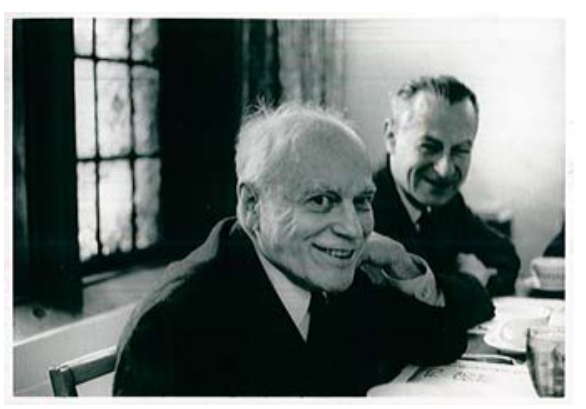

Marschak

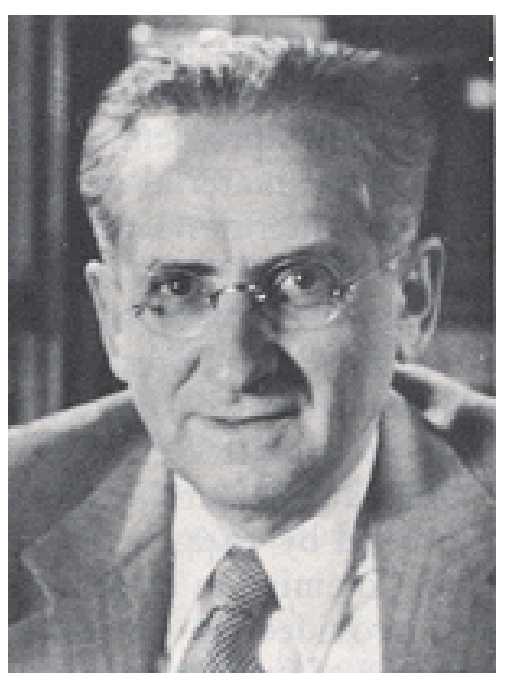



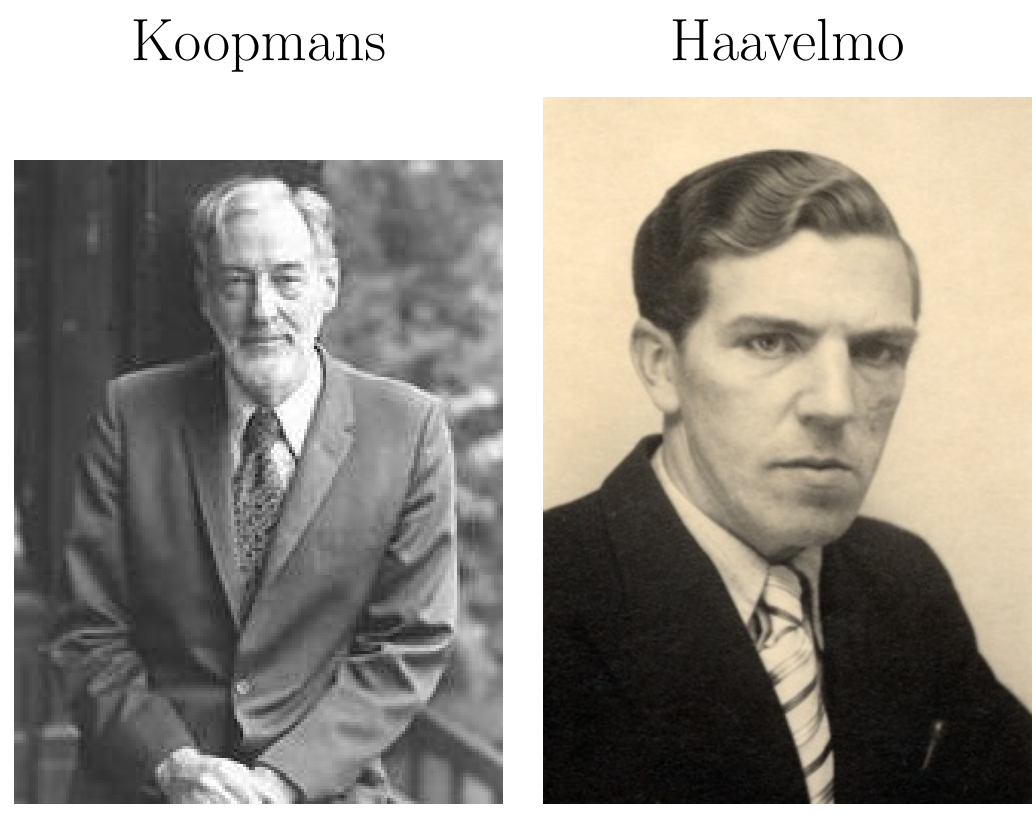

Friedman

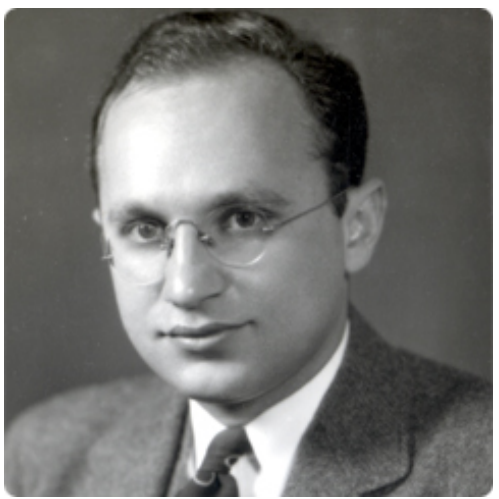

Becker contributed to both Chicago economics and the Chicago school.

His greatest contributions, however, are to Chicago economics. 


\section{Becker at Chicago}

(a) He did not rest on his laurels.

By 1976 (only 45 years old), he had crystallized the principles that guide and shape his work and continued a burst of creative activity.

\section{3 axioms}

(a) Maximizing behavior

(b) Mkt equilibrium

(c) Stable preferences

(b) At Chicago, he deepened and Expanded Themes of His Previous Work.

(c) Started a Line of Work on the Economics of the Family and Social Interactions

(Built on and extended work by Mincer)

(d) Returned to Fertility

(Students as stalking horses for his work and Willis) 
(e) Back to Duesenberry: He never dropped the issues raised by Duesenberry and realized how complex and poorly framed they were.

(i) Better understanding of the quantity-quality tradeoff (explained better the poor fit of his 1960s paper and why his quest for a positive income effect was unsuccessful)

(ii) With social interactions started incorporating analysis of peer effects and social norms. Defined these in a precise way.

(iii) Looked at preferences - and used human capital theory and concepts derived from it: social capital; consumption capital to explain patterns of behavior that seemed to violate rational choice. 
In his work with Lewis, his solo work on social interactions and his work with Barro, he refined and adapted the research on fertility. And in later joint work with Murphy, rephrased, made rigorous, and responded to Duesenberry some 40-50 years before. Culminated in a work with Kevin Murphy (Social Economics, 2000).

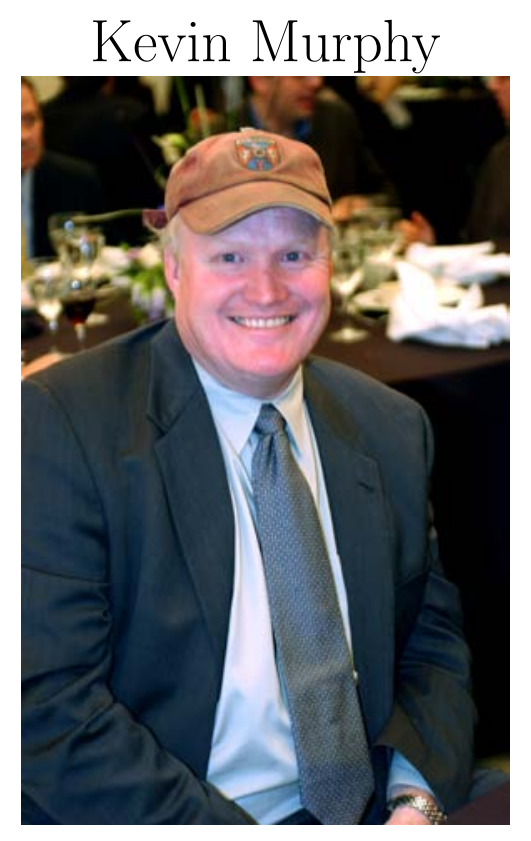

But this is only part of the enormous corpus of his work - could go on indefinitely. 


\section{The Temple of Becker}

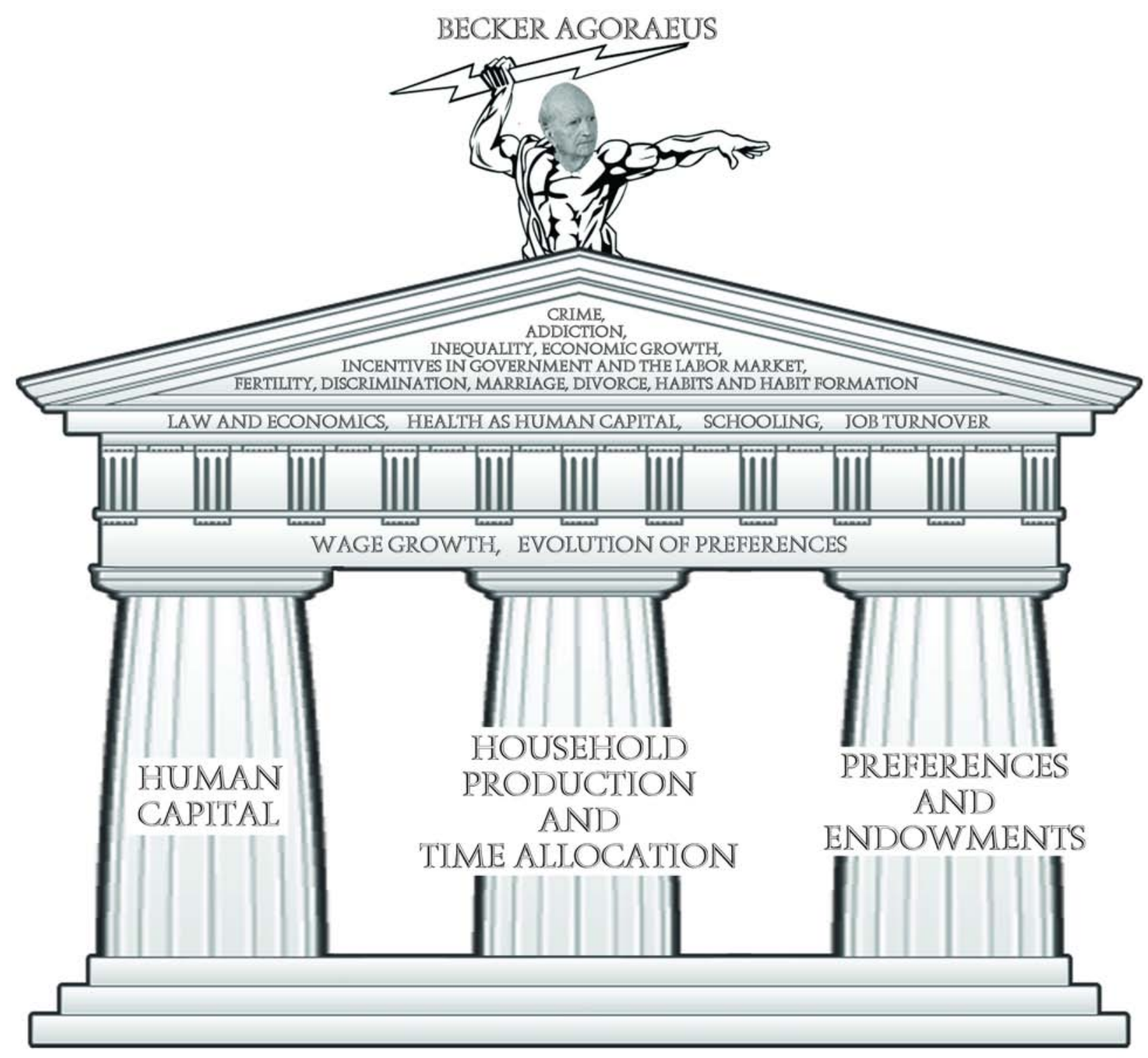


One Measure of the Man Is How Other IndependentMinded, Truly Outstanding Scholars Speak of Him

Posner on How Becker Influenced Law and Economics

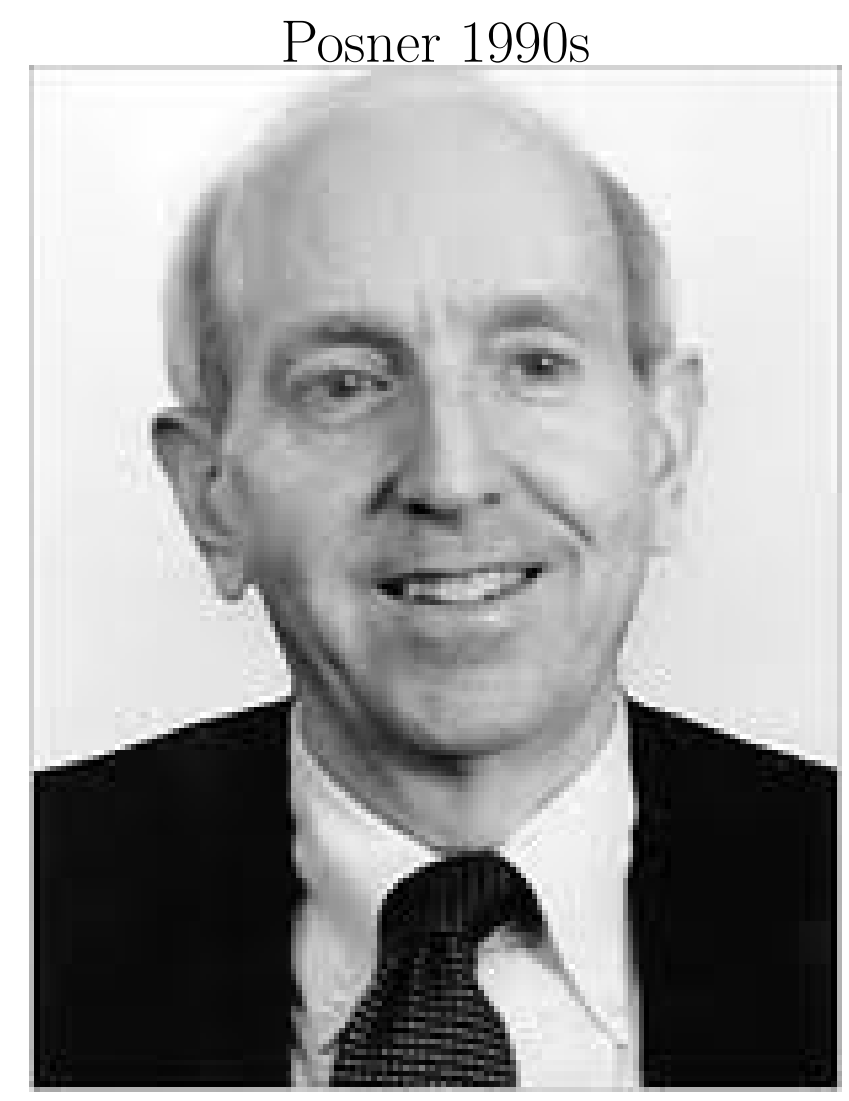


(a) Opened up a number of areas in law and economics

(i) Richard Epstein's work on employment at will (Gen and Spec. Human Capital)

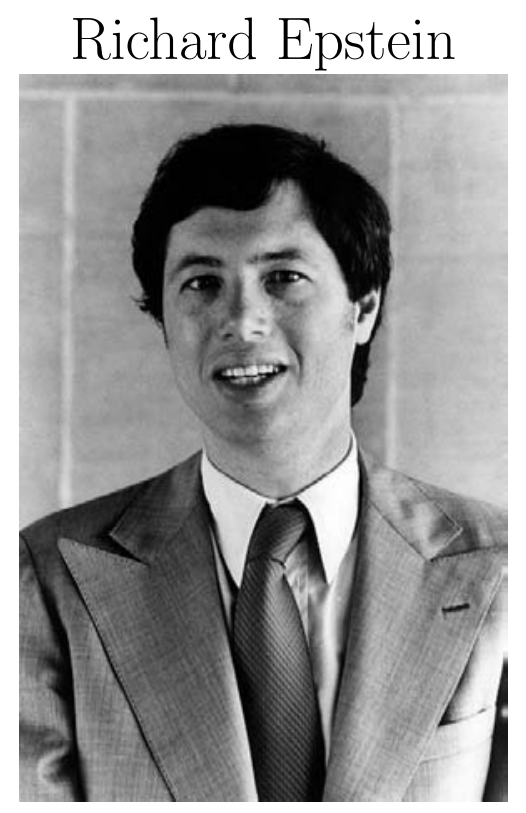

(ii) Private enforcement through backloading of payments(Explained "exploitative" contracts)

(iii) Household models — family law; no fault divorce, and sex discrimination — role of nonmarket sector

(iv) Models of time allocation of judges 
(b) Stimulated and fostered work of Bill Landes and Landes and Posner - 30 articles and books that laid the foundations.

(c) Like Bentham and beyond Coase, showed how economics characterizes all behavior and not just market behavior. A generalized cost benefit analysis. 
I started off with a comparison of Becker with Isaac Newton: Maybe a better comparison is with Jeremy Bentham?

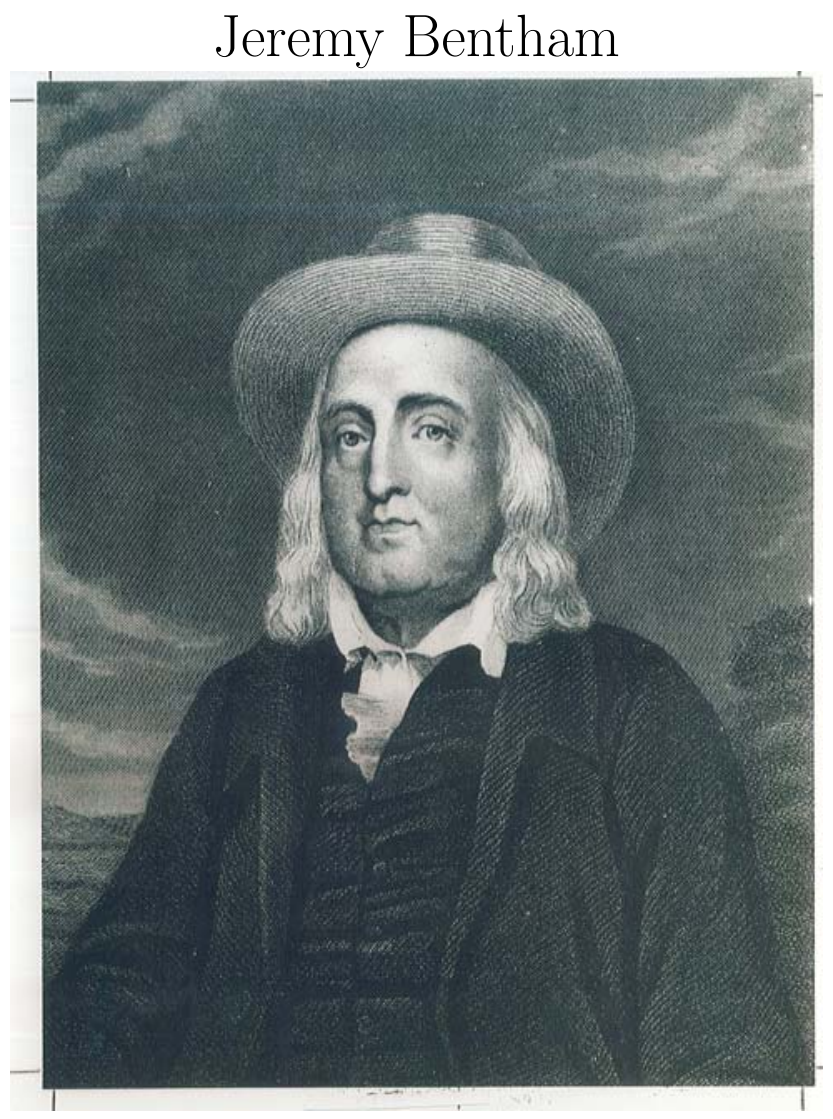

- Both applied cost-benefit analysis widely to a variety of problems.

- Both engaged in public policy discussions.

- BUT Bentham not only used cardinal measures of utility, but also was more focused on normative issues and public policy issues. 
- Becker was focused on positive issues, ordinal utility, and basic science that had positive effects.

- Fostered a Cumulative Empirical Social Science 


\section{Becker's Impact on Sociology (Coleman)}

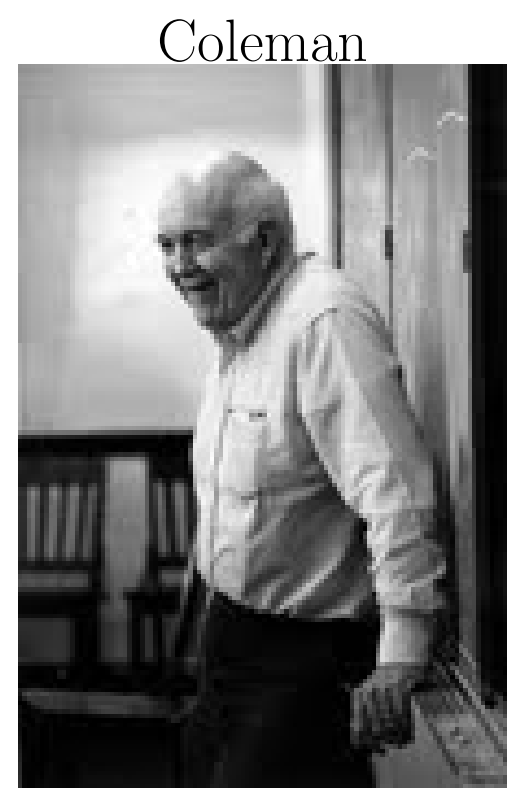


1. Field as a whole -introduced models to organize the masses of facts that characterize that field.

2. Discrimination - defined concept and made it up.

- Who benefits/who loses

3. Human capital - labor markets

- Framed status attainment and gave basis for understanding it.

- Understood role of family in producing schooling

- Labor force status: household sector (crude efficiency notions vs. opportunities)

4. Crime and punishment-incentives

- Beyond morality as a discussion of crime

- Look at efficiency and incentives as an alternative and perhaps complementary discussion

- Beyond crude psychology

- Changed criminology 
5. Family

- Fertility

- Division of labor

- Quantity-quality

- Non-market sector

6. Created Rational Choice Workshop

Becker and Posner at the Rational Choice Workshop

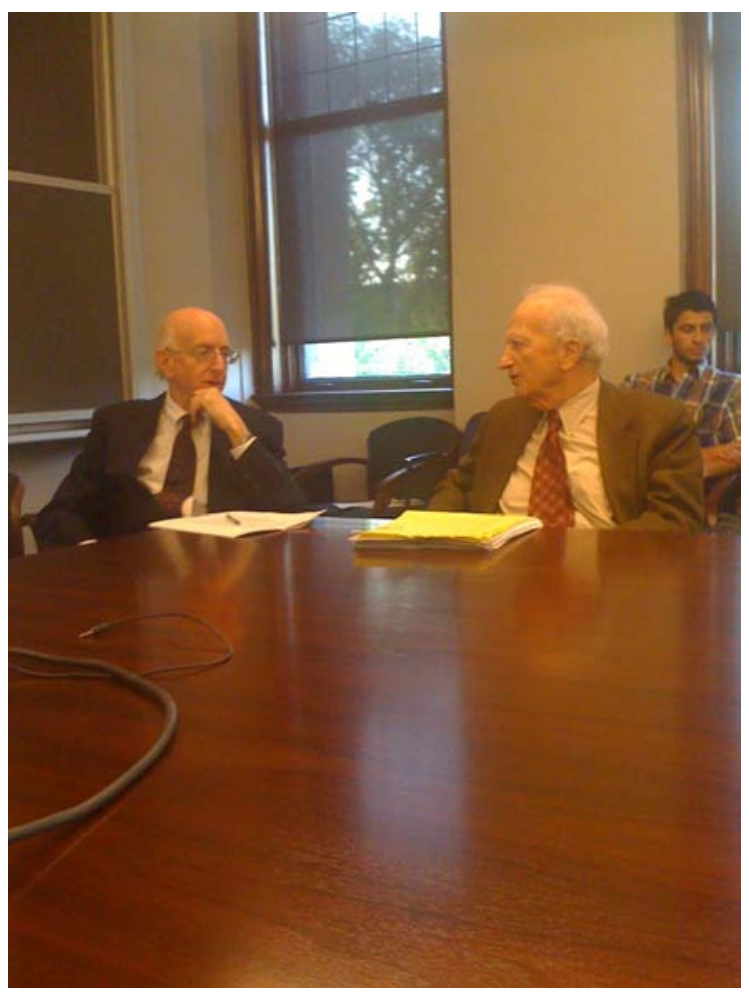




\section{Becker's Style - Why He Is So Influential}

1. Difference between working on problems and creating a literature

(a) Goal-not just to publish; Gary Becker's vitae is short as measured by length

(Over the past 55 years, about 100 papers and 14 books, about 2 papers a year.)

(Stigler quip to reporter comparing his vitae to Harry Johnson's. Quip — "Mine are all different.")

(b) Goal is to understand reality: crime, family, education, discrimination, etc.

(c) Not cute economics: not aim for "top five" and not for news.

2. Becker's work deals with strongly interrelated phenomena (not just isolated topics) 
(Same tools; applied to a wide variety of problems and extended as needed)

Work is convergent - it interacts and creates a web of interelated papers, a body of thought that, when it is put together, creates genuine knowledge. The work is cumulative - and mutually supporting -ingredients are enriched at each step but interrelated — not a "cute" paper or an interesting fact — although he had those - he also had a web of ideas and a circle of friends. There is continuity and there is growth.

3. Persisted; is a marathon runner. 


\section{The Temple of Becker}

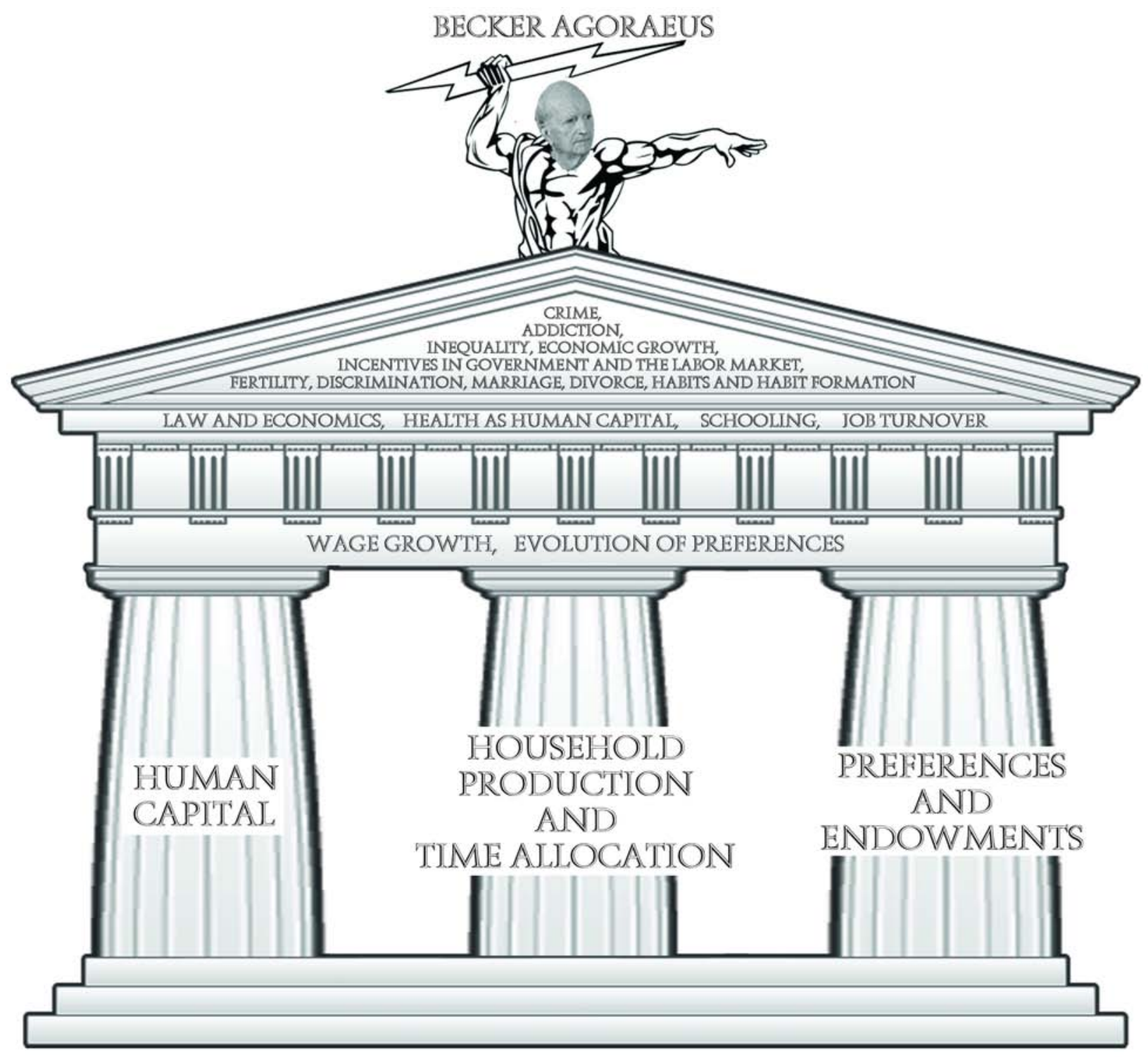




\section{Becker's Approach to Empirical Work}

(a) Posner on Becker at age 65 - Quoted The Trial of Galileo: (Bertolt Brecht)

Galileo in early 17th century is confronted by the Church; His observations with the newly created telescope contradict the views of Aristotle and challenge Church orthodoxy; Moons of Jupiter not in Aristotle violated received wisdom; Galileo asked cardinal and his philosophers and mathematicians to look at the sky with his newly discovered telescope. They refused to look. They know the truth.

(b) In Posner's vivid recounting and recasting of this play, Becker was cast as the cardinal who refused to look at the evidence and was strongly theory driven.

(c) I disagreed with that interpretation then and do so now and take the occasion some 15 years later to respond.

(d) Becker asks that the data be interpretable - that one can explain and link to other facts. 
(e) This is a model of science - not beliefs.

(f) A good example is the long quest to understand the economic and social forces explaining fertility.

(g) Deeper notion of the role of evidence than the blind empiricism of "Absolute Truth"

- Took from Cowles the value of Theory with Measurement

- All Measurement Requires Theory: (The idea of "getting the facts first" is an illusion.)

Theory Refines Measurement and Measurement Refines Theory

- His influence on empirical work enormous:

(1) Time Use: Whole Inventory of Studies Launched by His Work

(2) Education and Ability

(3) Structure of Educational Choices

(4) Marriage; Divorce (Rich Theories of Bargaining and Household allocations by Browning, Chiappori, and Weiss) 
(5) Data on Bargaining Within the Household

(h) Thus, while he does not do a lot of original empirical work, his knowledge, syntheses, and insights are staggering.

(i) He closely follows a huge array of work actively and in depth and encourages it.

(j) Fosters careful empirical work

(Less empirical than Friedman; less fussy than Lewis; but very well informed)

(k) His work came along at a time when masses of micro data on earnings, fertility, labor supply, just were collected-sharpened collection; Frank Stafford time use surveys

(l) Shaped questions and guided data collection 
(m) Empirical work-

How successful is the body of work empirically? The Story of Diminishing $R^{2}$

$R^{2} \downarrow$ as his research agenda advanced into the economics of the family

$R^{2}=.3-.4$ for earnings and schooling and experience

$R^{2}=.03-.04$ for marriage and divorce, fertility

Crime, capital punishment, etc.

His models explained part of the world but not all of it. 
(n) Story of Margaret Reid and her attack on Gary Becker

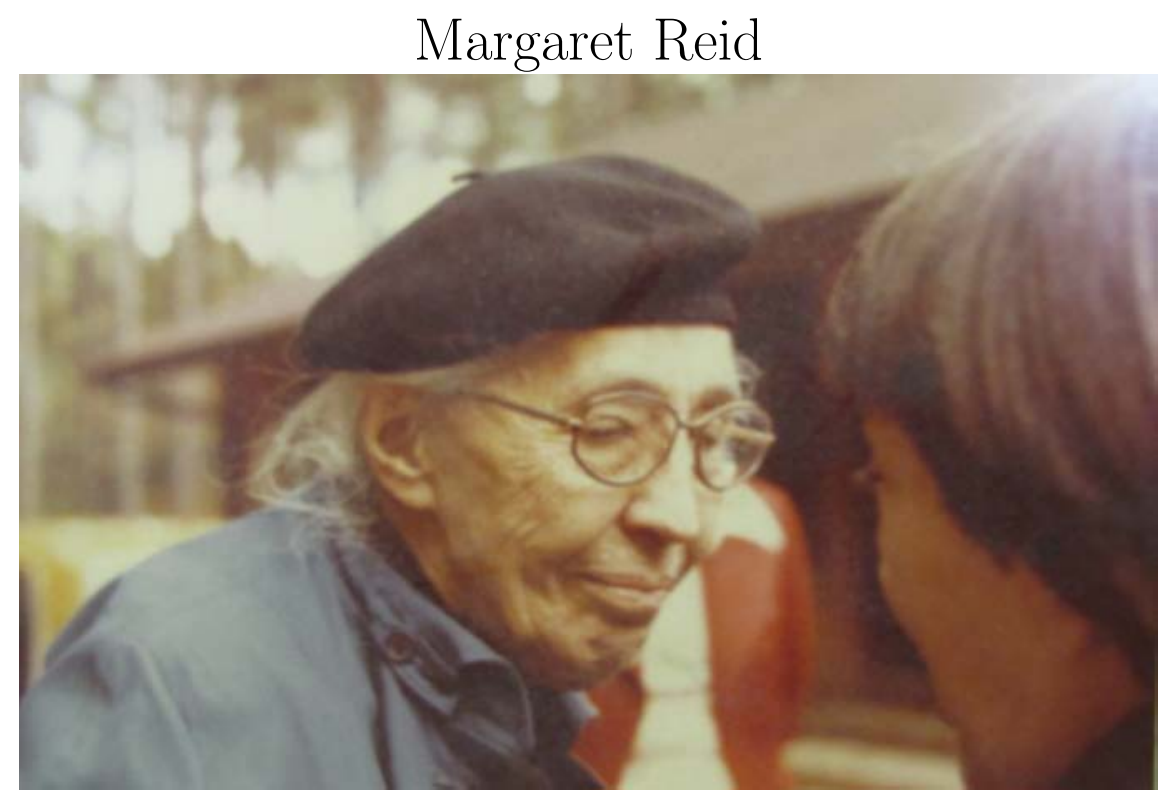

Took some severe beatings by Margaret Reid and rolled with it. (One aspect of his personality - resilience and openness.)

(o) Just as Newton failed to explain everything and knew that he did not - e.g., the 3-body problem — Becker admits more than most of his followers the gaps in our knowledge. 


\section{$\underline{B e c k e r ' s ~ E f f e c t ~ o n ~ P o l i c y ~ a n d ~ t h e ~ P o l i c y ~ D i s c u s s i o n ~}$}

- Clearly a member of the Chicago School (as well as the Department)

- Favors choice and market solutions but is not rigidly dogmatic.

- His influence: more subtle, less activist than Friedman, who openly entered politics in his 50s.

- Never served in government or actively campaigned (except for Dole campaign, 1996)

- Yet his influences are widespread

"The ideas of economists and political philosophers, both when they are right and when they are wrong, are more powerful than is commonly understood. Indeed the world is ruled by little else. Practical men, who believe themselves to be quite exempt from any intellectual influence, are usually the slaves of some defunct economist. Madmen in authority, who hear voices in the air, are distilling their frenzy from some 
academic scribbler of a few years back. I am sure that the power of vested interests is vastly exaggerated compared with the gradual encroachment of ideas." Keynes (1936, p. 383)

- War on Poverty: Henry Aaron has (1978) has written that Becker's work provided a framework for thinking about those policies advocated to reduce discrimination and promote human capital.

- One cannot go into discussions of the modern economy without discussing human capital and skill quality.

- Katz and Goldin call the $20^{\text {th }}$ Century the Human Capital Century.

- Served as an educator for the public on a range of policies.

- Like Friedman at Newsweek (and unlike Samuelson), Becker at Businessweek and with Posner write clearly and effectively on a variety of issues. 
May be Heretical to Say This, But His Impact on Economics as a Scientific Field: Arguably More Powerful and More Influential Than That of Milton Friedman

Again, saying this takes nothing away from Milton Friedman, who played a powerful role in shaping Gary Becker and in creating modern economics.

(a) Becker has influenced entire fields

e.g., current work on economics of the family

(Browning, Chiappori and Weiss)

$\rightarrow$ Time use

$\rightarrow$ Crime and punishment

$\rightarrow$ Rates of return to education

$\rightarrow$ Assignment problems with transferrable utility

$\rightarrow$ Economics of health

(b) Shapes the discussion even if many people disagree violently with him (e.g., Pollak; Bernheim and Rangel; Elster) 


\section{Why Has He Been So Successful? Why Has He Influenced Eco- nomics So Greatly?}

(a) Simplicity — deep simplicity; profoundly simple models with great universality

(i) Draws on and uses existing tools in creative ways Quantity-quality (Theil)

(ii) Assignment problem

(Brock; Koopmans and Beckmann)

Not ignorant simplicity or oversimplification.

His ideas are basic — intuitive, easily understood; they invite others to extend and apply them, and he encourages this actively — his great openness to experience has fostered whole schools of thought. 
(b) Tolerant of Recycling of His Work

Warmed Over Becker

(i) Wage $\neq$ MP (focused in signalling ...)

- Never a prediction of the theory - because of investment

(ii) Firms may pay for specific investment (monopsony, etc. warmed over versions by Acemoglu, etc.)

(iii) Lots of old wine in new bottles - must see this but tolerates it.

(c) He encouraged work on problems and engages with it. Openness to experience and learned from it.

(d) Resilient to Early Opposition: Ferocious and Ridicule: Has a deep sense of self confidence in his ideas.

- Solow, his fellow Madison alum (discrimination, marriage, and the like) tried to block publication of his theory of marriage.

- Blinder (1974) ("The Economics of Brushing Teeth," JPE) 
- He amazed me by saying it was interesting analysis - favored its publication - This is an example of his openness and agreeableness - willing to encourage all points of view.
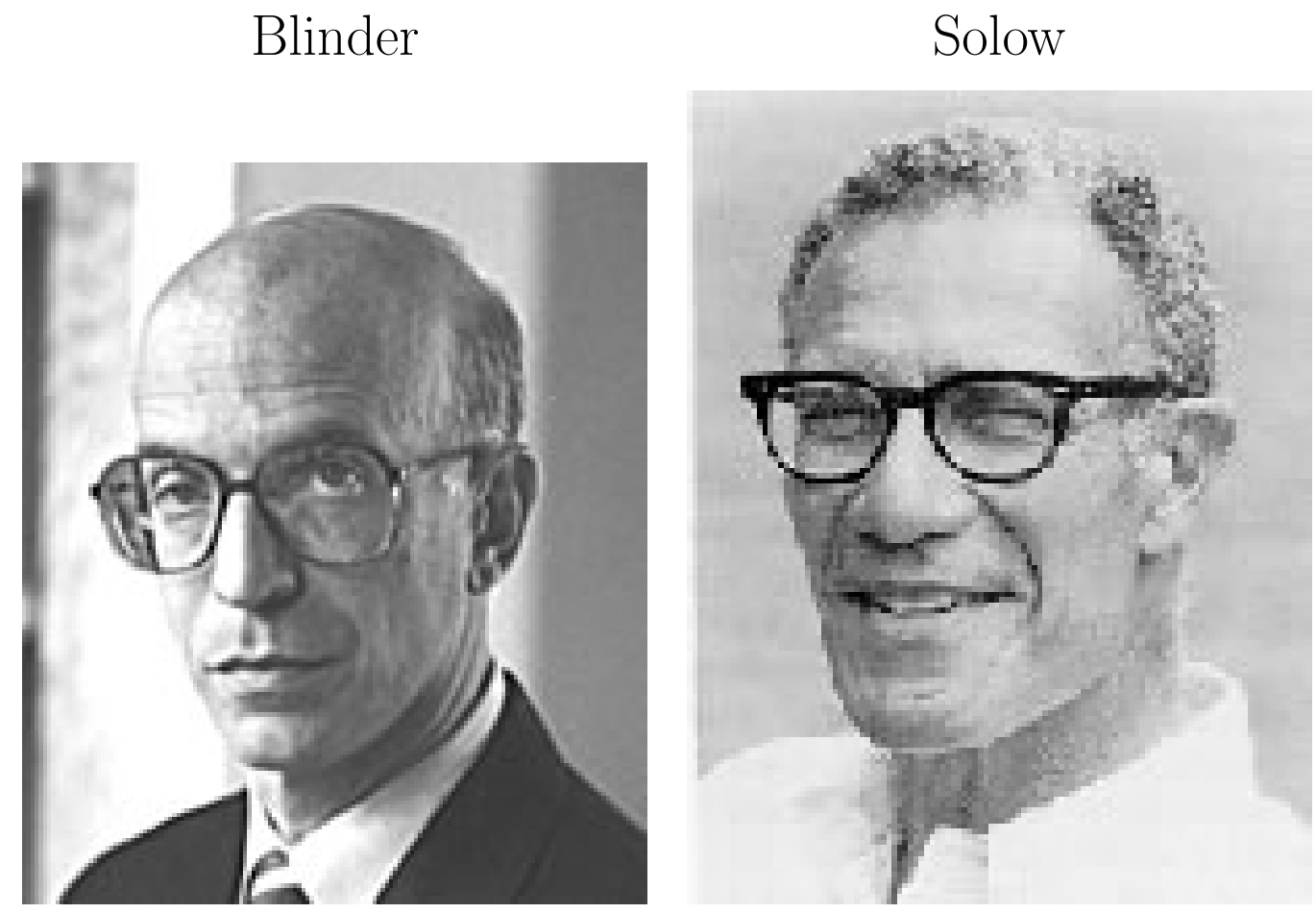

(e) In venturing far afield from conventional economics, he never lets go of the basic theory. Relates his work to that of past economists.

(f) Preserves the continuity of economic thought - continuity is the hallmark of any science - and clearly delineates how his work is new and how it is linked to the past. 
(g) Never loses his identity as an economist — and this is sometimes very hard to do. Many of us in this room have sometimes tried and failed.

\section{Becker Is Sincere}

(a) Freud, advising a young man who asked him how to succeed in academic life, said, "Exaggerate."

(b) If Becker were asked the same question, I suspect he would say, "Simplify the problem and its solution to its essence, clearly exposit it, and show that your solution is empirically relevant." Simplify, clarify, and test. 


\section{Through His Life and Work, He Has Shown the Power of Basic Economic Models}

He does more than repackage ideas outside of economics to economists.

(a) Behavioral Economics and "Animal Spirits": Power of Budget Constraint

Line of Defense is the Irrational Economics: However irrational people may be, they have to live within their means.

(b) Glimcher:

Contrast between Camerer and Paul Glimcher (Neuroeconomic Analysis, 2011) 
While he bucked trends in theory and formalism in economics, he also was supported by other trends and helped get them in motion. 


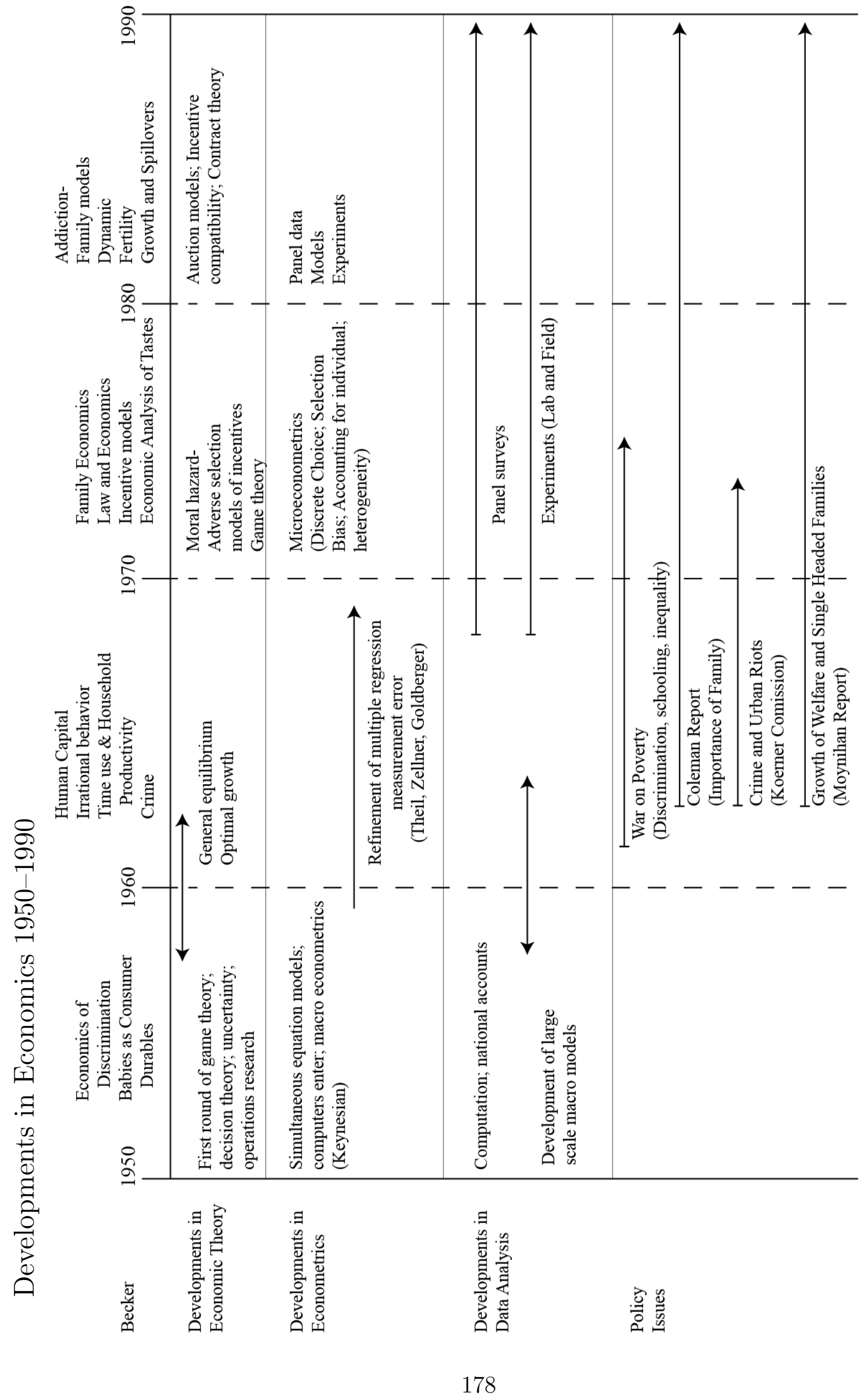


Becker Has Also Kept Alive and Fostered Price Theory at Chicago

Passing the Price-Theory Torch

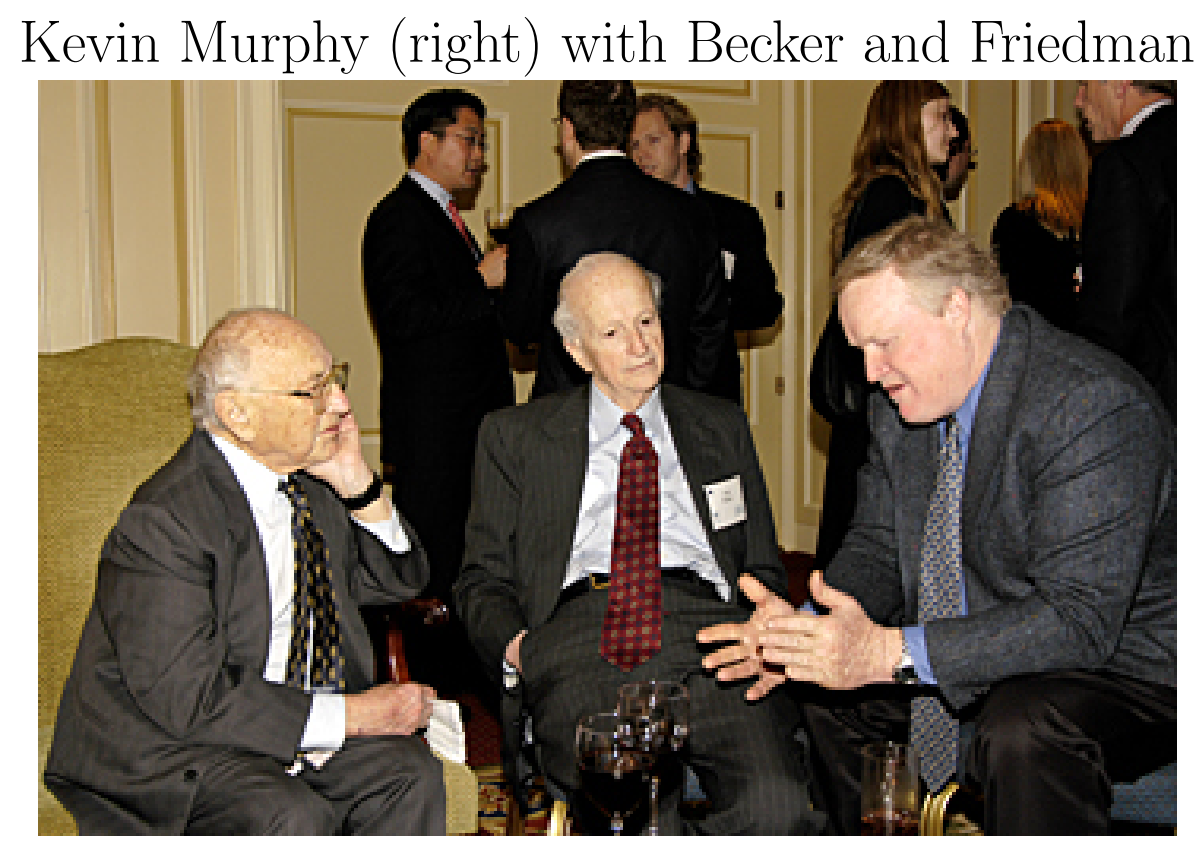


Becker and Murphy at Blackboard

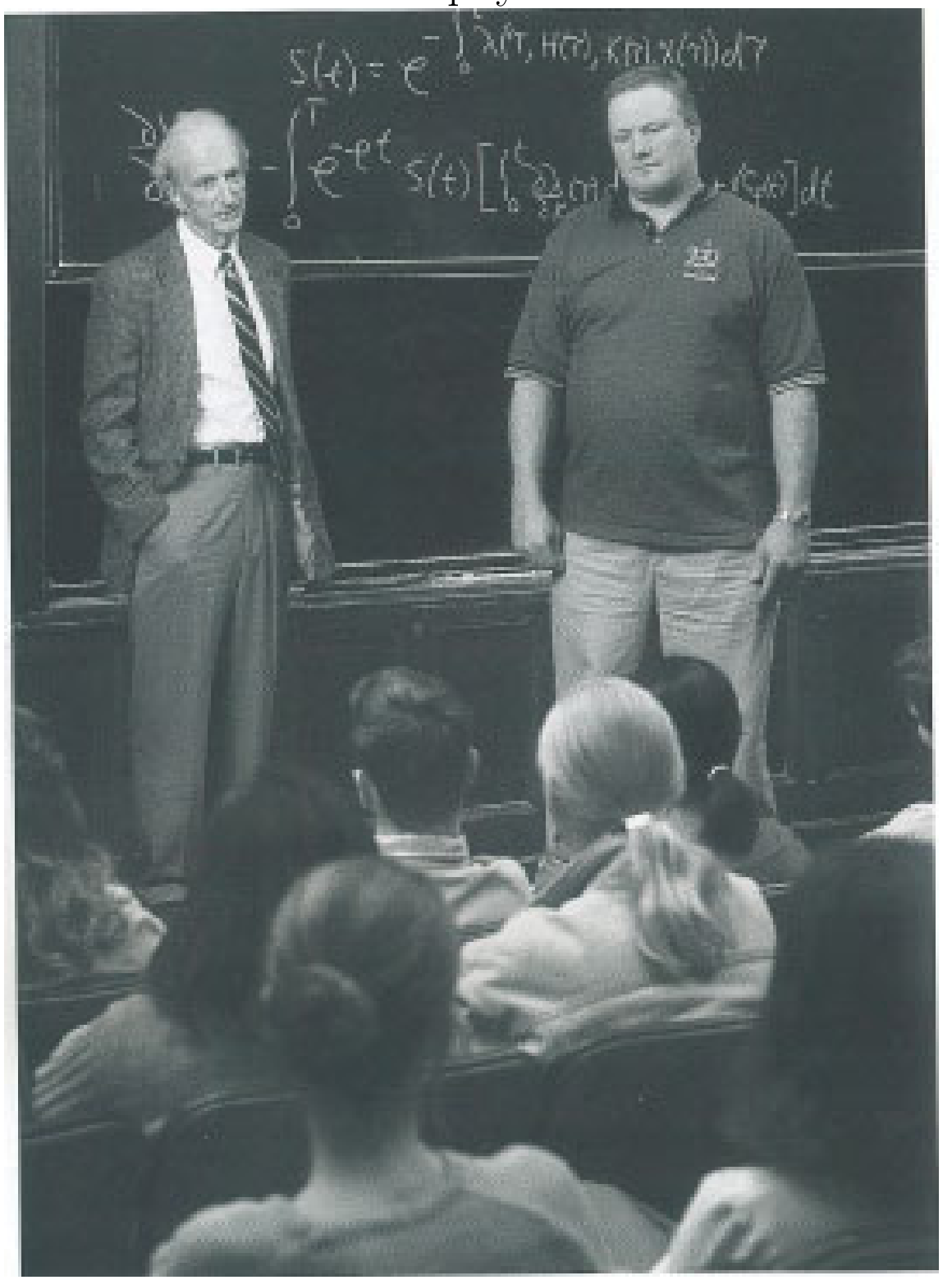


The best summary of the life and the influence of Gary Becker is in his own words:

"It [economics] is judged ultimately by how well it helps us understand the world, and how well we can help improve it." Gary Becker

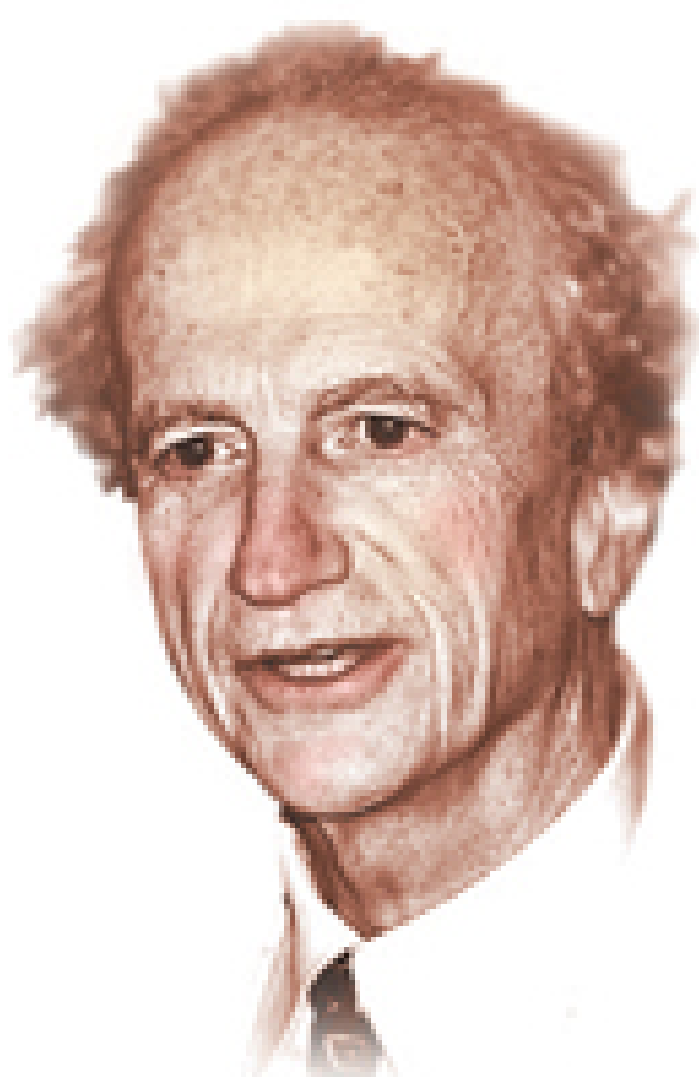




\section{References}

Becker, G. S. (1952, September). A note on multi-country trade. American Economic Review XLII(4), 558-568.

Becker, G. S. (1964). Human Capital: A Theoretical and Empirical Analysis, With Special Reference to Education. New York: National Bureau of Economic Research.

Becker, G. S. and W. J. Baumol (1952, November). The classical monetary theory: The outcome of the discussion. Economica $X I X(76), 355-376$.

Blinder, A. S. (1974). The economics of brushing teeth. The Journal of Political Economy 82(4), 887-891.

Keynes, J. M. (1936). The General Theory of Employment, Interest and Money. London: Macmillan and Co., Limited.

Keynes, J. M. (1963). Essays in Biography, Chapter Newton, the Man, pp. 310-323. New York, NY: W.W. Norton and Company, Inc. 
Stigler, G. J. (1970). Review of Lord Robbins" "The evolution of modern economic theory". Economica 37, 425-426. 